\title{
On the $\mathrm{N}$-arylation of acetamide using 2-, 3- and 1'-substituted iodoferrocenes
}

\author{
Lingaswamy Kadari, ${ }^{a, b}$ William Erb, ${ }^{a *}$ Yury S. Halauko, ${ }^{* *}$ Oleg A. Ivashkevich, ${ }^{d}$ Vadim E. Matulis, ${ }^{d}$ \\ Dmitry Lyakhov, ${ }^{\mathrm{e}}$ Thierry Roisnel, ${ }^{a}$ Palakodety Radha Krishna ${ }^{\mathrm{b*}}$ and Florence Mongin ${ }^{\mathrm{a}}$
}

a Univ Rennes, CNRS, ISCR (Institut des Sciences Chimiques de Rennes)-UMR 6226, F-35000 Rennes, France. E-mail: william.erb@univ-rennes1.fr

b Organic Synthesis and Process Chemistry Division, CSIR-Indian Institute of Chemical Technology, Hyderabad, 500007, India. E-mail: prkgenius@iict.res.in

UNESCO Chair of Belarusian State University, 14 Leningradskaya Str., Minsk 220030, Belarus. E-mail: hys@tut.by

d Research Institute for Physico-Chemical Problems of Belarusian State University, 14 Leningradskaya Str., Minsk 220030, Belarus

e Computer, Electrical and Mathematical Science and Engineering Division, 4700 King Abdullah University of Science and Technology, Thuwal 23955-6900, Saudi Arabia

\begin{abstract}
Various 2-, 3- and 1'-substituted iodoferrocenes were reacted with acetamide in the presence of copper(I) iodide (1 equiv), $N, N$ '-dimethylethylenediamine (1 equiv), tripotassium phosphate $(2$ equiv) in dioxane at $90{ }^{\circ} \mathrm{C}$ for $14 \mathrm{~h}$, and allowed a large range of original 1,2-, 1,3- and 1,1'-disubstituted ferrocenes to be obtained. The results were compared as a function of the substituent and its position on the ring. DFT calculations revealed higher activation barrier for the oxidative addition in the ferrocene series when compared with classical planar aromatics. Structure-property relationships were applied to rationalize the reactivity of the different iodoferrocenes.
\end{abstract}

\section{Introduction}

The $\mathrm{N}$-arylation of amides, also known as the Goldberg condensation, ${ }^{[1]}$ and above all its copper-catalyzed variants that don't require harsh reaction conditions, ${ }^{[2]}$ have demonstrated their value for the multistep synthesis of bioactive compounds such as antagonists of VLA-4 (very late antigen-4) protein, ${ }^{[3]}$ inhibitors of PDE5 (phosphodiesterase-5) enzyme, ${ }^{[4]}$ antiplasmodials, ${ }^{[5]}$ inhibitors of tankyrase protein, ${ }^{[6]}$ inhibitors of $\mathrm{Xa}$ factor, ${ }^{[7]}$ inhibitors of trypanosome proliferation ${ }^{[8]}$ and inhibitors of EGFR (epidermal growth factor receptor) tyrosine protein kinase. ${ }^{[9]}$

This success results from the discovery of efficient catalytic systems able to operate under smooth conditions, such as the one developed by Buchwald and co-workers consisting of a combination of an air stable copper(I) salt, an aliphatic chelating 1,2-diamine and a base to $N$-arylate amides by halides $(\mathrm{I}>\mathrm{Br}>$ Cl). ${ }^{[10]}$ As regards mechanism, it is admitted that the reaction between the aryl halide and a 1,2-diamine ligated copper(I) amidate giving a copper(III) species is the rate determining step that precedes reductive elimination. ${ }^{[11]}$ As a consequence, the reaction outcome is a function of both the aryl halide and the amide as the ability of the latter to stabilize an aryl-Cu(III)-amido species would have a significant impact on the course of the reaction. ${ }^{[12]}$ Steric hindrance and poor nucleophilicity of the amidate are the reasons generally invoked to explain why the scope of copper-catalyzed $\mathrm{N}$-arylation of amides is not larger. ${ }^{[13]}$ With regard to the aryl halide, it has been demonstrated that a methyl group present at the ortho position of iodobenzene hampers to some extent its reaction with 2-pyrrolidinone. ${ }^{[11 c]}$ Besides, it has been shown in 2009 that iodobenzenes bearing electron-deficient groups at their 4 position facilitate the reaction $(\mathrm{CN}>\mathrm{COMe}>\mathrm{Cl}>\mathrm{H})$ while others bearing electron-donating groups jeopardize $(\mathrm{OMe}<\mathrm{Me}<\mathrm{H})$ the aryl iodide activation. ${ }^{[11 \mathrm{~b}]}$ A similar conclusion was made by reacting both benzamide and 2-pyrrolidinone with iodobenzenes bearing either electronwithdrawing 4-nitro group or electron-donating 4-methyl group. ${ }^{[12 c]}$ However, from planar aryl iodides, the reaction generally tolerates a large range of substituents as shown in the benzene series (2- and 4-OMe, 2- and 4- $\mathrm{NMe}_{2}, 4-\mathrm{NH}_{2}$, 2- and 3$\mathrm{Me}$, 2-iPr, 4-SMe, 3- $\mathrm{CH}_{2} \mathrm{OH}$, 3- $\mathrm{CH}_{2} \mathrm{NH}_{2}$, 3-CN, 3-COMe, 4-Cl, 4$\mathrm{CH}_{2} \mathrm{CN}$, 4-CONHR, 4- $-\mathrm{CO}_{2} \mathrm{R}$ and 2- $\mathrm{NO}_{2}$ ) and by the use of thiophene and azine/diazine halides. ${ }^{[10]}$

Notably due to their three-dimensional structure and ability to undergo facile one-electron oxidation, ferrocenes are quite different from benzenes. While ferrocene and its derivatives have found numerous applications, ${ }^{[14]}$ they exhibit their own behavior in several reactions. ${ }^{[15]}$ Consequently, as coppercatalyzed $\mathrm{N}$-arylation of carboxamides using iodobenzenes is currently well-described, the corresponding reaction in the ferrocene series remains in its infancy. Indeed, whereas iodoferrocene can react with amides by recourse to copperbased systems, ${ }^{[16]}$ the involvement of 2-substituted derivatives in such couplings is far less obvious due to competitive deiodination. ${ }^{[16 c]}$ While continuing our work dedicated to the synthesis of ferrocene amides, ${ }^{[17]}$ we recently reported the successful $\mathrm{N}$-arylation using iodoferrocene of a large range of carboxamides. ${ }^{[18]}$

In the continuation of our efforts to develop synthetic methods in the ferrocene series and to understand their specific behavior, ${ }^{[17,19]}$ we were eager to study the effect of an additional substituent at the 2-, 3- or 1'-position of iodoferrocene on the amide $\mathrm{N}$-arylation. To this goal, 35 substituted iodoferrocenes were engaged in the copper-mediated $\mathrm{N}$-arylation reaction, leading to 28 original $\mathrm{N}$-ferrocenyl acetamides, isolated in moderate to good yields which were tentatively linked to the structural and electronic features of the iodo partners.

\section{Results and Discussion}

\section{Synthesis of the $\mathrm{N}$-ferrocenyl acetamides}

From the literature on the $\mathrm{N}$-arylation of amides using iodoferrocene (1a), two catalytic systems were selected for this study: (i) the one reported in 2007 by Bolm and co-workers using copper(I) iodide and potassium tert-butoxide in dimethylsulfoxide (DMSO) at $90^{\circ} \mathrm{C},{ }^{[16 c]}$ and (ii) the other we recently reported based on the use of copper(I) iodide, $N, N^{\prime}$ - 
dimethylethylenediamine (DMEDA) and tripotassium phosphate in dioxane at $90{ }^{\circ} \mathrm{C} .^{[18]}$ Early evaluation of Bolm's system ${ }^{[16 \mathrm{c}]}$ starting from 2-substituted iodoferrocenes bearing $\mathrm{CH}_{2} \mathrm{OMe}$, $\mathrm{CO}_{2} \mathrm{Me}$ or $\mathrm{CONiPr}_{2}$ moieties only afforded the corresponding products in low yields (19, 4.5 and $6.5 \%$, respectively) partly due to competitive deiodination $(16,37$ and $54.5 \%$ yield, respectively). As the other conditions were able to deliver $N$ ferrocenylacetamide (2a) in $82 \%$ yield from iodoferrocene (1a) (Scheme 1), this protocol was selected to study the substituent impact on the course of the copper-mediated acetamidation of iodoferrocenes (Table 1).

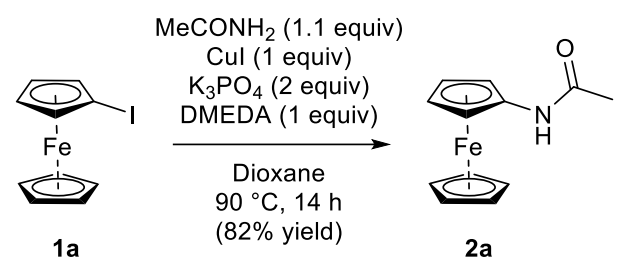

Scheme 1. $\mathrm{N}$-arylation of acetamide with iodoferrocene.

Thus, the coupling reactions between acetamide and the 35 synthesized 2-, 3- or 1'-substituted iodoferrocenes 1 b-m, 3b-m and $\mathbf{5 b}$-I were all performed in the presence of copper $(\mathrm{I})$ iodide (1 equiv), $N, N$ '-dimethylethylenediamine (DMEDA; 1 equiv) and tripotassium phosphate (2 equiv) in dioxane at $90{ }^{\circ} \mathrm{C}$ for $14 \mathrm{~h}$. Most of the expected 1,2-, 1,3- and 1,1'-disubstituted ferrocenes 2b-m, 4b-m and 6b-I were obtained, albeit in yields depending on both the substituent present on the initial iodoferrocene and its position. In particular, the products $\mathbf{2 d}, \mathbf{2} \mathbf{i}$ and $\mathbf{2} \mathbf{j}$, already obtained respectively in 19, 4.5 and $6.5 \%$ yields from the iodoferrocenes $\mathbf{1 d}, \mathbf{1} \mathbf{i}$ and $\mathbf{1 j}$ by using Bolm's procedure, were isolated in 61,51 and $15 \%$ yields by using our protocol (entries 7, 22 and 25). It is interesting to note that, besides the starting substituted iodoferrocene, the corresponding deiodoferrocene was also present at the end of most of these reactions.

\section{Oxidative addition as rate determining step}

It is in general admitted in the benzene series that the rate determining step of a copper-catalyzed amidation is the oxidative addition, more precisely the reaction between the aryl halide and the 1,2-diamine ligated copper(I) amidate, reaction that gives a copper(III) species. ${ }^{[11 c, 20]}$ Thus, we first tried to analyze our experimental results by using the data reported on oxidative additions.

Table 1. $\mathrm{N}$-arylation of acetamide with 2-, 3- and 1'-substituted iodoferrocenes.

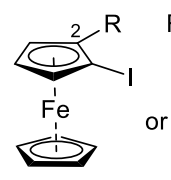

1

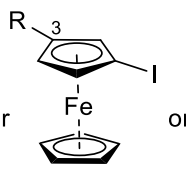

3

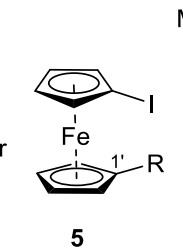

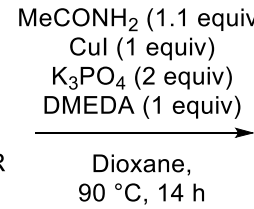

$90^{\circ} \mathrm{C}, 14 \mathrm{~h}$

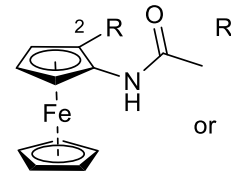

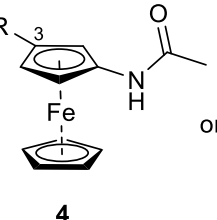

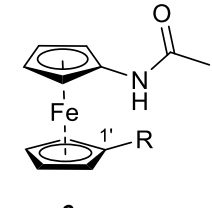

6

\begin{tabular}{|c|c|c|}
\hline Entry & lodoferrocene, R & Product, Yield (\%)a) \\
\hline 1 & 1b, 2-Me & $2 b, 61^{b)}$ \\
\hline 2 & $3 b, 3-\mathrm{Me}^{[19 i]}$ & $4 \mathbf{b}, 65^{\mathrm{c})}(21 ; 7)^{\mathrm{b})}$ \\
\hline 3 & $5 \mathbf{b}, 1^{\prime}-\mathrm{Me}^{[19 j]}$ & $6 b, 80^{b)}$ \\
\hline 7 & $1 \mathrm{~d}, 2-\mathrm{CH}_{2} \mathrm{OMe}$ & $2 \mathrm{~d}, 61^{\mathrm{b})}$ \\
\hline 8 & $3 d, 3-\mathrm{CH}_{2} \mathrm{OMe}^{[19 i]}$ & $4 d, 51^{d)}(34 ; 5)^{b)}$ \\
\hline 9 & $\mathbf{5 d}, 1^{\prime}-\mathrm{CH}_{2} \mathrm{OMe}^{[19 j]}$ & $6 d, 67^{b), c)}$ \\
\hline 13 & 1f, $2-\mathrm{CHO}^{[25]}$ & 2f, $12^{\mathrm{c})}(-; 55)^{\mathrm{b})}$ \\
\hline 14 & 3f, 3-CHO ${ }^{[19 i]}$ & 4f, $\left.12(49 ; 15)^{b}\right)$ \\
\hline 15 & $5 f, 1^{\prime}-\mathrm{CHO}^{[19 j]}$ & $6 f, 30^{b)}$ \\
\hline 19 & $1 \mathrm{~h}, 2-\mathrm{CN}^{[25]}$ & $2 \mathrm{~h}, 24^{\mathrm{b})}$ \\
\hline 20 & $3 \mathbf{h}, 3-\mathrm{CN}^{[19 i]}$ & $4 \mathrm{~h}, 30^{\mathrm{c})}(-; 70)^{\mathrm{b})}$ \\
\hline 21 & $5 \mathbf{h}, 1^{\prime}-\mathrm{CN}^{[19 j]}$ & $6 h, 40^{b)}$ \\
\hline 22 & $1 \mathrm{i}, 2-\mathrm{CO}_{2} \mathrm{Me}^{[25]}$ & $2 \mathrm{i}, 51^{\mathrm{b})}$ \\
\hline 23 & $3 \mathbf{i}, 3-\mathrm{CO}_{2} \mathrm{Me}^{[19 i]}$ & $4 \mathbf{i}, 37(10 ; 53)^{b)}$ \\
\hline 24 & $5 \mathbf{i}, 1^{\prime}-\mathrm{CO}_{2} \mathrm{Me}^{[19 j]}$ & $6 i, 54^{b)}$ \\
\hline 28 & $1 \mathbf{k}, 2-\mathrm{NMe}_{2}[26]$ & $2 \mathbf{k}, 0^{\mathrm{b})}$ \\
\hline 29 & $3 \mathbf{k}, 3-\mathrm{NMe}_{2}{ }^{[19 i]}$ & 4k, $28(-; 26)^{b)}$ \\
\hline 30 & $5 \mathbf{k}, 1-\mathrm{NMe}_{2}{ }^{[19 j]}$ & $6 \mathrm{k}, 0^{f)}$ \\
\hline 34 & $1 \mathrm{~m}, 2-\mathrm{F}^{[19 \mathrm{c}]}$ & $2 \mathrm{~m}, 34^{\mathrm{d})}(19 ; 25)^{\mathrm{b})}$ \\
\hline 35 & $3 m, 3-F^{[19 g]}$ & $\left.4 m, 57^{c)}(5 ; 20)^{b}\right)$ \\
\hline
\end{tabular}

\begin{tabular}{|c|c|c|}
\hline Entry & lodoferrocene, $\mathrm{R}$ & Product, Yield (\%) \\
\hline 4 & 1c, 2- $\mathrm{CH}_{2} \mathrm{NiPr}_{2}$ & 2c, $0^{\text {b) }}$ \\
\hline 5 & $3 \mathbf{c}, 3-\mathrm{CH}_{2} \mathrm{NiPr}_{2}{ }^{[19 a]}$ & $4 c, 66^{b)}$ \\
\hline 6 & $5 \mathbf{c}, 1^{\prime}-\mathrm{CH}_{2} \mathrm{NiPr}_{2}{ }^{[19 j]}$ & $6 c, 52^{b)}$ \\
\hline 10 & $1 \mathrm{e}, 2-\mathrm{CH}_{2} \mathrm{OH}$ & $2 \mathrm{e}, 0^{\mathrm{b})}$ \\
\hline 11 & $3 e, 3-\mathrm{CH}_{2} \mathrm{OH}^{[19 i]}$ & $4 e, 25(25 ; 17)^{b)}$ \\
\hline 12 & $5 e, 1^{\prime}-\mathrm{CH}_{2} \mathrm{OH}^{[19 j]}$ & $6 e, 18^{b)}$ \\
\hline 16 & 1g, 2-COPh[25] & $2 \mathrm{~g}, 13^{\mathrm{b})}$ \\
\hline 17 & $\mathbf{3 g}, 3-\mathrm{COPh}^{[19 i]}$ & $\mathbf{4 g}, 19(-; 56)^{\mathrm{b})}$ \\
\hline 18 & $\mathbf{5 g}, 1^{\prime}-\mathrm{COPh}^{[19 j]}$ & $6 \mathrm{~g}, 25^{\mathrm{b})}$ \\
\hline
\end{tabular}

a) After purification (see experimental part). b) The rest was mainly recovered starting material (1, $\mathbf{3}$ or $\mathbf{5})$ and the corresponding deiodinated ferrocene; for some reactions, the respective yields are given in brackets. ${ }^{c)}$ Average yield over two experiments. ${ }^{\text {) }}$ Average yield over three experiments. e) The rest was mainly the deiodinated ferrocene. ${ }^{\text {f) }}$ Decomposition under the conditions used for the reaction

The ease by which oxidative addition of aryl halides by palladium(0) species takes place inversely depends on the energy to distort the carbon-halogen bond to the transition state geometry which is related to the $\mathrm{C}-\mathrm{X}$ bond dissociation energy (and in the order $\mathrm{I}>\mathrm{Br}>\mathrm{Cl}>\mathrm{F}$, and six-membered ring $>$ fivemembered ring). Furthermore, it might also depend on the LUMO of the arene (favored frontier molecular orbitals interactions), and consequently on the presence of substituents 
(with electron-withdrawing groups > electron-donating groups). ${ }^{[21]}$

Various approaches were reported in the literature, in the case of substrates bearing multiple identical halogens, to predict the regioselectivity of palladium-catalyzed coupling reactions for which oxidative addition is also rate determining. Indeed, when two carbons of a substrate bear identical halogens, the preferred reaction site in general corresponds to the most electrondeficient carbon. ${ }^{[22]}$ While calculating the activation energy of the oxidative addition is the most accurate way to predict a

Because we benefited from the complete NMR data of all the 2-, 3- and 1'-iodoferrocenes $1 \mathrm{~b}-\mathrm{m}, 3 \mathrm{~b}-\mathrm{m}$ and $5 \mathrm{~b}-\mathrm{I}$, the experimental results were compared by using a similar simplified approach in the light of the NMR chemical shifts of the carbons bearing iodine. In order to more easily analyze the results, in addition to the chemical shifts $\delta(\mathrm{C}-\mathrm{I})$ of the different iodoferrocenes, the values relative to iodoferrocene (1a) were calculated and also given in brackets (Table 2).

On the basis of their ${ }^{13} \mathrm{C}$ NMR spectra, the substituents Me and $\mathrm{CH}_{2} \mathrm{NiPr}_{2}$ should exhibit similar electronic effects. Indeed, they make the $\delta(\mathrm{C}-\mathrm{I})$ values increase significantly on their adjacent site (substrates 1b,c) and, to a lesser extent, on the other cyclopentadienyl $(\mathrm{Cp})$ ring $(\mathbf{5 b}, \mathbf{c})$ but have no effect at the remote 3-position (3b,c) (Table 2, entries 2 and 3 ). As a consequence, oxidative addition should be favored by the presence of $\mathrm{Me}$ or $\mathrm{CH}_{2} \mathrm{NiPr}_{2}$ at $\mathrm{C} 2$ (substrates $\mathbf{1 b}, \mathbf{c}$ ) or $\mathrm{C}^{\text {' }}$ $(5 \mathbf{b}, \mathbf{c})$, but no effect should be noticed at C3 $(\mathbf{3 b}, \mathbf{c})$. Indeed, the presence of $\mathrm{Me}$ and $\mathrm{CH}_{2} \mathrm{NiPr}_{2}$ at $\mathrm{C} 3$ has only a slight and similar impact on the coupling yields (65 and $66 \%$ yields, respectively, from $\mathbf{3 b}, \mathbf{c}$ against $82 \%$ from iodoferrocene (1a); Table 1, entries 2 and 5). As expected, the yield from $\mathbf{5 b}$ is higher than from $\mathbf{3 b}$ (Table 1, entries 2 and 3 ) while the lower $61 \%$ yield noticed when $\mathrm{Me}$ is at $\mathrm{C} 2$ can be rationalized by steric hindrance (entry 1). However, although a moderate $52 \%$ yield was observed with $\mathrm{CH}_{2} \mathrm{NiPr}_{2}$ at $\mathrm{C1}^{\prime}$ (entry 6), the reaction did not take place at all when present at $\mathrm{C} 2$ (entry 4 ). In the search of a clue to explain this result, our reference coupling between iodoferrocene (1a) and acetamide (Scheme 1) was attempted in the presence of 1 regioselectivity, ${ }^{[21 a]}$ comparing NMR chemical shifts - and thus the electronic environment - at different sites of a compound has been used as a simplified approach. In 2006, Handy and Zhang proposed to use the ${ }^{1} \mathrm{H}$ NMR chemical shift values of the corresponding dehalogenated arenes to this purpose, the most deshielded proton being in general attached to the preferred site of cross-coupling. ${ }^{[23]}$ The same year, Fairlamb and co-workers rather used the ${ }^{13} \mathrm{C}$ NMR chemical shifts of the halogenated arenes as a way to provide insight into the electrophilicities. ${ }^{[24]}$

equivalent of (diisopropylaminomethyl)ferrocene. While this additive proved mostly recovered $(74 \%)$, the yield of the coupled product 2a dropped to $35 \%$, indicating that an effect other that steric hindrance - maybe competitive coordination - could be at the origin of this lack of reactivity.

Both substituents $\mathrm{CH}_{2} \mathrm{OMe}$ and $\mathrm{CH}_{2} \mathrm{OH}$ increase rather significantly the $\delta(\mathrm{C}-\mathrm{I})$ values of their neighboring sites but no longer-range impact is noticed in these cases (Table 2, entries 4 and 5). Consequently, they should favor oxidative addition at C2 (substrates 1d,e) and have no effect at C3 $(\mathbf{3 d}, \mathbf{e})$ or C1 $(\mathbf{5 d}, \mathbf{e})$. However, in spite of a slightly higher yield from $\mathbf{1 d}$ than from $3 \mathbf{d}$, the behavior of $\mathrm{CH}_{2} \mathrm{OMe}$ in the reactions rather looks like that of $\mathrm{Me}\left(61,51\right.$ and $67 \%$ yield for $\mathrm{CH}_{2} \mathrm{OMe}$ respectively at $\mathrm{C} 2, \mathrm{C} 3$ and $\mathrm{C}^{\prime}$ ' against 61,65 and $80 \%$ in the case of Me; Table 1, entries 7-9 and 1-3). The $\mathrm{CH}_{2} \mathrm{OH}$ function impacts differently the outcome of the reactions. As observed with $\mathrm{CH}_{2} \mathrm{NiPr}_{2}$ (entry 4), the reaction did not occur at all in the presence of $\mathrm{CH}_{2} \mathrm{OH}$ at $\mathrm{C} 2$ (entry 10) while those with $\mathrm{CH}_{2} \mathrm{OH}$ at $\mathrm{C} 3$ and $\mathrm{C} 1$ ' were greatly hampered (entries 11 and 12). In the presence of ferrocenemethanol (1 equiv) as additive in our reference coupling between iodoferrocene (1a) and acetamide (Scheme 1$)$, the reaction was impacted ( $47 \%$ yield) and $81 \%$ of the additive was recovered. Therefore, as alcohol seems compatible with the reaction conditions to limited extent, the lower yields recorded from compounds $1 e, 3 e$ and $5 e$ might result from an intramolecular coordination that impedes the reaction.

Table 2. ${ }^{13} \mathrm{C}$ NMR chemical shift of the $\mathrm{C}-\mathrm{I}$ in $\mathrm{CDCl}_{3}$ for the different iodoferrocenes involved in the reaction with acetamide.

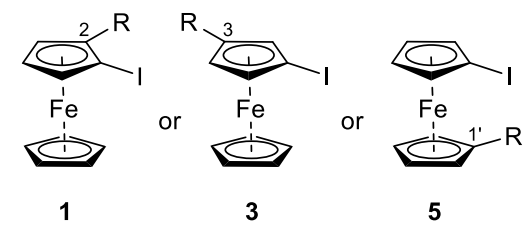

\begin{tabular}{|c|c|c|c|c|c|}
\hline \multirow{2}{*}{ Entry } & \multirow{2}{*}{ Substrate } & \multirow{2}{*}{$\mathrm{R}$} & \multicolumn{3}{|l|}{$\delta(\mathrm{C}-\mathrm{I})[\Delta \delta]^{\mathrm{a})}$} \\
\hline & & & 1 & 3 & 5 \\
\hline 1 & $\mathbf{a}$ & $\mathrm{H}$ & 39.9 & & \\
\hline 2 & b & $\mathrm{Me}$ & $46.6[+6.7]$ & $39.7[-0.2]$ & $40.9[+1.0]$ \\
\hline 3 & C & $\mathrm{CH}_{2} \mathrm{NiPr}_{2}$ & $45.4[+5.5]$ & $39.8[-0.1]$ & $41.0[+1.1]$ \\
\hline 4 & $d$ & $\mathrm{CH}_{2} \mathrm{OMe}$ & $45.0[+5.1]$ & $39.8[-0.1]$ & $40.1[+0.2]$ \\
\hline 5 & e & $\mathrm{CH}_{2} \mathrm{OH}$ & $43.9[+4.0]$ & $39.7[-0.2]$ & $40.1[+0.2]$ \\
\hline 6 & $f$ & $\mathrm{CHO}$ & $42.0[+2.1]$ & $41.3[+1.4]$ & $39.4[-0.5]$ \\
\hline 7 & g & $\mathrm{COPh}$ & $41.1[+1.2]$ & $41.3[+1.4]$ & $40.0[+0.1]$ \\
\hline 8 & h & $\mathrm{CN}$ & $41.6[+1.7]$ & $38.6[-1.3]$ & $39.8[-0.1]$ \\
\hline 9 & i & $\mathrm{CO}_{2} \mathrm{Me}$ & $39.8[-0.1]$ & $40.0[+0.1]$ & $40.4[+0.5]$ \\
\hline 10 & j & $\mathrm{CONiPr} 2$ & $40.5[+0.6]$ & $39.6[-0.3]$ & $40.1[+0.2]$ \\
\hline 11 & $k$ & $\mathrm{NMe}_{2}$ & $38.7[-1.2]$ & $39.7[-0.2]$ & $40.6[+0.7]$ \\
\hline 12 & I & $\mathrm{NHCO}_{2} t \mathrm{Bu}$ & $37.7[-2.2]$ & $37.6[-2.3]$ & $42.6[+2.7]$ \\
\hline 13 & m & $\mathrm{F}$ & $28.9[-11.0]$ & $33.6[-6.3]$ & - \\
\hline
\end{tabular}

a) $\Delta \delta=\delta(\mathrm{C}-\mathrm{I})$ of the disubstituted ferrocene $-\delta(\mathrm{C}-\mathrm{I})$ of iodoferrocene. 
The $\mathrm{CHO}$ and COPh functions slightly deshield the carbons at $\mathrm{C} 2$ and at $\mathrm{C} 3$ but have no effect on the other Cp ring (Table 2 , entries 6 and 7). Thus, oxidative addition should be favored on the substituted ring (substrates $\mathbf{1 f}, \mathbf{g}$ and $\mathbf{3} \mathbf{f}, \mathbf{g}$ ) whereas no change is expected on the other ring $(\mathbf{5} \mathbf{f}, \mathbf{g})$. However, the results did not follow these predictions. On the one hand, the 2-, 3- and 1 '-substituted ferrocene carboxaldehydes (2f, 4f, 6f; Table 1, entries 13-15) and phenyl ketones (2g, $\mathbf{4 g}, \mathbf{6 g}$; entries 16-18) were only isolated in moderate yields ranging from 12 to $30 \%$; on the other hand, the 1,1'-disubstituted products $\mathbf{6 f}$ and $\mathbf{6 g}$ were produced in higher yields than the 1,2 and 1,3disubstituted ones. However, due to the low stability of these aldehyde- and ketone-containing ferrocenes, drawing a clear conclusion is difficult.

As far as the $\mathrm{CN}$ function is concerned, it makes the $\delta(\mathrm{C}-\mathrm{I})$ values slightly increase when located at $\mathrm{C} 2$ and slightly decrease at C3; in contrast, it has no impact on the other $\mathrm{Cp}$ ring (Table 2, entry 8). As expected, the yield is lower with a CN group fixed at C3 (product $4 \mathrm{~h}$ ) than at C1' (6h); however, $\mathbf{2 h}$ was obtained in a yield lower than expected (Table 1, entries 19-21). Even if it is with higher yields in the case of $\mathrm{CN}(24,30$ and $40 \%$, respectively, for the substituent at C2, C3 and C1'; products $2 \mathrm{~h}$, 4h and $6 \mathrm{~h}$ ), the reactivity trend $\mathrm{C} 1^{\prime}>\mathrm{C} 3>\mathrm{C} 2$ already observed with phenyl ketone is here reproduced. Since we suspected the high affinity for copper of $\mathrm{CN}$ to be partly responsible for the lower yields recorded when compared with iodoferrocene (1a), our reference reaction between $\mathbf{1 a}$ and acetamide was carried out in the presence of ferrocenecarbonitrile (1 equiv). Under these conditions, the coupled product $2 \mathbf{a}$ was isolated in a moderate $38 \%$ yield due to recovered 1a (41\% yield; no deiodination took place in this case while the nitrile was completely recovered). Thus, the presence of the nitrile function seems to impact negatively the course of the reaction.

The presence of a $\mathrm{CO}_{2} \mathrm{Me}$ or a $\mathrm{CONiPr}_{2}$ function onto iodoferrocene has nearly no impact on the $\delta(\mathrm{C}-\mathrm{I})$ values, regardless of its position from the iodo group (Table 2, entries 9 and 10). However, the yields of the $\mathrm{C}-\mathrm{N}$ bond formation reactions were in general somewhat lower than those recorded for iodoferrocene (1a) (Table 1, entries 22-27). The moderate $15 \%$ yield obtained in the presence of $\mathrm{CONiPr}_{2}$ at $\mathrm{C} 2$ can easily be rationalized by the important size of this group; indeed, the yield increased to $77 \%$ with the same substituent located at C3 (products $\mathbf{2} \mathbf{j}$ and $\mathbf{4 j}$, entries 25 and 26). Concerning the moderate $39 \%$ yield obtained for compound $6 \mathbf{j}$, it is possible that, although $\mathrm{Cp}$ rings are free to rotate, an intramolecular interaction involving the $\mathrm{CONiPr}_{2}$ might occur, placing this bulky substituent close to the reaction center as observed with compound $\mathbf{6 j}$ (Figure 3, bottom). In the case of $\mathrm{CO}_{2} \mathrm{Me}$, the three yields were rather close, as expected (products $\mathbf{2} \mathbf{i}, \mathbf{4} \mathbf{i}$ and $\mathbf{6 i}$; entries 22-24). Both groups seem to impact reactions taking place at the other $\mathrm{Cp}$ ring (products $\mathbf{6 i}$ and $\mathbf{6 j}$, entries 24 and 27 ).

$\mathrm{NMe}_{2}, \mathrm{NHCO}_{2}$ tBu and, above all, $\mathrm{F}$ have in common an ability to make the $\delta(\mathrm{C}-\mathrm{I})$ values decrease significantly on the adjacent site and, to a lesser extent, at the remote 3-position; in contrast, they shield the carbon signals on the other $\mathrm{Cp}$ ring (Table 2, entries 11-13). As a consequence, the oxidative addition should be easier with the substituent at $\mathrm{C}^{1}$ ' and more difficult with the substituent on the same ring. In the $\mathrm{NMe}_{2}$ series, even if $\mathbf{4 k}$ could be isolated ( $28 \%$ yield), the products proved unstable and their degradation occurred under the conditions used for the reaction (Table 1, entries 28-30). In the case of $\mathrm{NHCO}_{2} t \mathrm{Bu}$, as anticipated, the best result was obtained with the substituent at C1' (product 6I, entry 33) while lower 8.5 and $17 \%$ yields were noticed from the two other substrates (products $\mathbf{2 l}$ and $\mathbf{4 I}$, respectively; entries 31 and 32). The lower yield noticed for ferrocene $1 \mathrm{l}$ might further result from steric hindrance that would be less important in the case of $\mathbf{3 l}$. In the case of $F$, the results are as predicted, with products $2 \mathrm{~m}$ and $\mathbf{4 m}$ respectively isolated in 34 and $57 \%$ yield (entries 34 and 35 ).

All these results show that, if predictions can be made in a few cases $\left(\mathrm{F}, \mathrm{NHCO}_{2} \mathrm{tBu}\right.$ and, to a lesser extent, $\mathrm{CH}_{2} \mathrm{OMe}(\mathrm{C} 2$ $>\mathrm{C} 3), \mathrm{Me}\left(\mathrm{C}^{\prime}{ }^{\prime}>\mathrm{C} 3\right)$ and $\left.\mathrm{CN}\left(\mathrm{C}^{\prime}{ }^{\prime}>\mathrm{C} 3\right)\right)$, the predictive approach based on the $\delta(\mathrm{C}-\mathrm{I})$ values can be hardly applied to the ferrocene series, while it works rather well for planar aromatic and heteroaromatic halides.

In order to understand the underlying reasons, we tried quantitative structure-properties relationships (QSPR) approach and electronic structure methods. We adopted Handy's proposal in a sense that 'prototype' deiodinated ferrocenes were used to find correlations (we believe this reasonable, regarding low electronegativity difference, so that $\mathrm{H}$ to I substitution can be treated like a perturbation). Furthermore, we excluded the substrates e, j, $\mathbf{k}, \mathbf{I}$, for which yield is strongly influenced by steric hindrance or specific interactions, rather than electronic effects. A range of conceptual density functional theory (CDFT) descriptors has been calculated (Table S1; see Supporting Information). These could be classified into local and global properties. Recall that all investigated structures have ferrocene part in an eclipsed conformation. In addition, only bare ferrocene and prototypes of $\mathbf{b}, \mathbf{h}$ and $\mathbf{m}$ have vertical plane of symmetry; hence, for the rest of the structures, the local descriptors of the carbons corresponding to the substituted ring were averaged (C2 with C5, C3 with C4).

Regarding the quite high temperature and reaction time, we assumed yield to be a solid measure of reactivity. When trying to describe yield (\%y) on a single-variable basis, one could obtain best model:

$\% y=126-118 \omega\left(N=23, r^{2}=0.75\right)$.

Experimental and predicted yields were compared graphically in Figure S1 (see Supporting Information). This result could be interpreted as follows: yield decreases with increasing electrophilicity index $(\omega)$, meaning that electrondonating groups in general favor the process.

In order to have a better understanding of the reactivity, we averaged yield over positions of parent ferrocenes (Table S2; see Supporting Information) and repeated regression analysis. A similar model equation was obtained:

$$
\% y=122-114 \omega\left(N=9, r^{2}=0.70\right) \text {. }
$$

Furthermore, it is obvious that steric factor could be pronounced for substituents at C2 and C1', so we decided to probe yield at $\mathrm{C} 3$ only as 'most pure' with respect to electronic influence. In addition to similar

$\% y=135-132 \omega\left(N=9, r^{2}=0.82\right)$,

we obtained an even better model:

$\% y=-1484-6500 q_{\mathrm{NBO}}\left(N=9, r^{2}=0.88\right)$,

which means more negative natural bond orbital atomic charge $\left(q_{\mathrm{NBO}}\right)$ on carbon favors the corresponding $N$-ferrocenyl acetamide's yield.

Interestingly, no prominent correlation between $\delta(\mathrm{C}-\mathrm{I})$ values and descriptors on a single-variable basis exists. Therefore, it is better to rationalize the reactivity of the different iodoferrocenes in view of their global molecular properties rather than to local carbon descriptors.

\section{Comparison with the corresponding benzenes}

When compared with the literature about similar transformations in the benzene series, iodoferrocenes clearly appear as less 
reactive. In the event that oxidative addition is the rate determining step, it is known from the literature that its ease is related to both the carbon-halogen bond strength and the electronic environment. ${ }^{[21]}$ Several bond dissociation energies (BDE; enthalpy change for homolytic cleavage of the $\mathrm{C}-\mathrm{X}$ bond) have been calculated by Merlic, Houk and co-workers and the results show that the strength of the $\mathrm{C}-\mathrm{X}$ bond of a fivemembered heteroaromatic is in general stronger than the equivalent bond in a six-membered ring. ${ }^{[21 b]}$ This trend, as well as the low stability of the ferrocenyl radical when compared with the phenyl radical, ${ }^{[27]}$ tend to indicate that the oxidative addition of iodoferrocene (1a) is more difficult than for iodobenzene. In addition, with respective values of $94.3^{[28]}$ and $39.9 \mathrm{ppm}$, the $\operatorname{NMR} \delta(\mathrm{C}-\mathrm{I})$ of iodobenzene and $1 \mathrm{a}$ are in favor of a much easier oxidative addition for the former. These data are also supported by a study dedicated to the comparison of oxidative additions from different iodinated derivatives of cyclopentadienyl complexes that evidenced a lower reactivity for iodoferrocene (1a) when compared with corresponding metal-carbonyl complexes. ${ }^{[29]}$

The free energy of activation for the oxidative addition of iodobenzene, iodoferrocene (1a) and the 3-substituted iodoferrocenes $\mathbf{3 b}$, $\mathbf{3} \mathbf{f}$ and $\mathbf{3} \mathbf{h}$ to the [(dmeda)Cu(pyrr)] complex (pyrr = 2-pyrrolidinone) has been computed, and the results are summarized in Table 3 . The computed energy barrier for the reaction of [(dmeda)Cu(pyrr)] complex with iodobenzene (24.7 $\mathrm{kcal} / \mathrm{mol}$, Table 3) is in a good agreement with the value of 25 $\mathrm{kcal} / \mathrm{mol}$ calculated by Tye and co-workers for the reaction in toluene. ${ }^{[11 \mathrm{c}, 30]}$ The predicted energy barrier for iodoferrocene (1a) is much higher (28.5 kcal/mol, Table 3$)$, which agrees well with the lower reactivity of iodoferrocenes when compared with the corresponding iodobenzenes. Our calculations show that the energy barriers for reactions of [(dmeda)Cu(pyrr)] complex with the considered 3 -substituted iodoferrocenes $\mathbf{3 b}, \mathbf{3 f}$ and $\mathbf{3 h}$ are close, but slightly higher than for the unsubstituted iodoferrocene. In addition to coordination and stability issues, it is thus not surprising that low reactivities were in general noticed from our substituted iodoferrocenes when compared with the corresponding benzenes.

Table 3. Calculated free energy of activation $\left(\Delta G^{*}\right)$ for the reactions of $[(\mathrm{dmeda}) \mathrm{Cu}($ pyrr $)]$ complex with iodobenzene, iodoferrocene (1a) and the 3 substituted iodoferrocenes $\mathbf{3 b}$, $\mathbf{3}$ f and $\mathbf{3 h}$.

\begin{tabular}{ll}
\hline Substrate & $\Delta G^{ \pm}(\mathrm{kcal} / \mathrm{mol})$ \\
\hline iodobenzene & 24.7 \\
1a & 28.5 \\
3b & 30.1 \\
3f & 29.1 \\
3h & 28.9 \\
\hline
\end{tabular}

Houk and co-workers considered selectivity in palladiumcatalyzed cross-couplings of halogenated heterocycles in terms of molecular orbital control. ${ }^{[21]}$ Generally, effective interactions require orbitals of similar energy and correspondent symmetry. In addition to interactions, responsible for the bondforming/breaking processes, other stabilizing frontier molecular orbitals (FMO) interactions are possible. But our calculations predict principal FMO differences between haloarenes, haloheteroaromatics, and haloferrocenes (Scheme 2). (a)

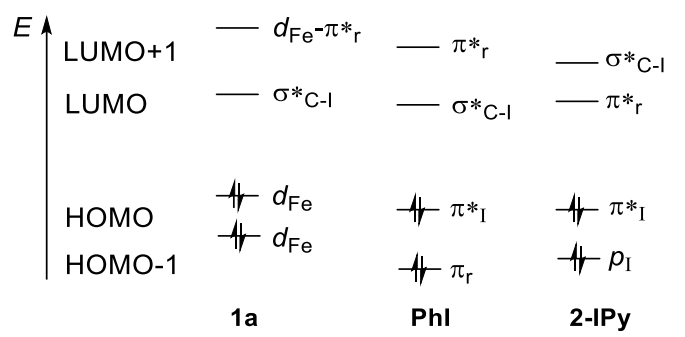

(b)

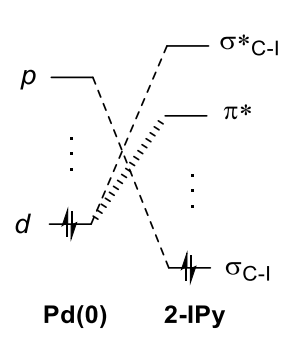

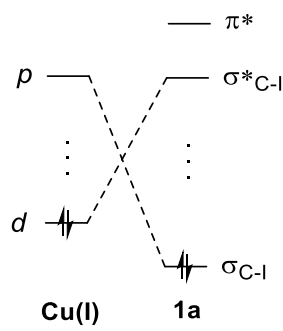

Scheme 2. (a) FMO profile of the selected species; (b) schematic representation of the allowed interactions between 2-iodopyridine (2-IPy) and Pd(0)[21a] vs those of iodoferrocene (1a) and $\mathrm{Cu}(\mathrm{I})$.

HOMO and HOMO-1 of iodoferrocene (1a) could be described as mainly $d$ orbitals of iron. ${ }^{[1]}$ For iodobenzene and 2-iodopyridine (2-IPy), HOMOs are antibonding $\pi$ orbitals. LUMO and LUMO+1 of 2-iodopyridine are antibonding $\pi$ orbital and $\sigma^{*}(\mathrm{C}-\mathrm{I})$, correspondingly. When coming to iodobenzene and 1a, the LUMO and LUMO+1 order is swapped (Scheme 2a). Thus, the oxidative addition transition state for iodoferrocenes can hardly be stabilized by $\left(d-\pi^{*}\right)$ back-donation mentioned by Houk (for a schematic representation, see Scheme 2b). ${ }^{[21 a]}$ This in turn can partially describe why electron-deficient groups do not increase the amidation yield. In addition, by considering the transition state geometry for the reaction of [(dmeda)Cu(pyrr)] complex with iodoferrocene (1a), electrostatic and van der Waals interactions are likely to occur between iodine and iron/second ring atoms (see Supporting Information).

Even if oxidative addition is generally considered as the rate determining step of this copper-catalyzed amidation, we analyzed the possibility of a decisive reductive elimination step as a function of the substituent and its position. Indeed, although it was in palladium-catalyzed amination, Hartwig and co-workers showed that reductive elimination with $\mathrm{C}-\mathrm{N}$ bond formation was influencing for series of five-membered heteroaryl halides, with less electron-rich aryl moiety favoring the process. ${ }^{[32]}$ To this purpose, the Mulliken charges on carbons were calculated (Table 4; B3LYP calculations with a 6-31G(d) basis set). These calculations show that the introduction of substituents at $\mathrm{C} 3$ or C1' have a very limited impact on the electron-rich character of the ferrocenyl group. Logically, the effect is more significant when the substituent is fixed at $\mathrm{C} 2$. With $\mathrm{F}$ and, to a lesser extent, $\mathrm{CHO}, \mathrm{COPh}, \mathrm{Me}$ and $\mathrm{CH}_{2} \mathrm{OMe}$, the corresponding 2-substituted ferrocenyl is more electron-rich, and reductive elimination should be disfavored. This might partly (together with oxidative addition) explain the low yield observed from $1 \mathbf{m}$; however, this could hardly explain why the yields of the couplings from $\mathbf{1 b}, \mathbf{1 d}$ and $\mathbf{1 g}$ are not at the maximal value in spite of high $\delta$ (C-I) (Table 1). 
Table 4. Carbon Mulliken charges calculated for the deiodinated ferrocenes corresponding to some of the different iodoferrocenes involved in the reaction with acetamide.

\begin{tabular}{|c|c|c|c|c|c|}
\hline \multirow{2}{*}{ Substrate } & & \multirow{2}{*}{$\mathrm{R}$} & \multicolumn{3}{|l|}{ Mulliken [ $\Delta$ Mulliken] ${ }^{\mathrm{a})}$} \\
\hline & & & At $\mathrm{C} 2$ & At C3 & At C1' \\
\hline \multirow{9}{*}{${ }_{11}^{13}$} & $\mathbf{a}$ & $\mathrm{H}$ & -0.134 & & \\
\hline & b & $\mathrm{Me}$ & $-0.152[-0.018]$ & $-0.133[+0.001]$ & $-0.138[-0.004]$ \\
\hline & $\mathbf{c}$ & $\mathrm{CH}_{2} \mathrm{NiPr}_{2}$ & $-0.135 /-0.139[-0.003]$ & $-0.131 /-0.135[+0.001]$ & $-0.138[-0.004]$ \\
\hline & d & $\mathrm{CH}_{2} \mathrm{OMe}$ & $-0.137 /-0.155[-0.012]$ & $-0.139 /-0.131[-0.001]$ & $-0.132[+0.002]$ \\
\hline & f & $\mathrm{CHO}$ & $-0.148 /-0.163[-0.0215]$ & $-0.121 /-0.128[+0.0095]$ & $-0.134[0]$ \\
\hline & $\mathbf{g}$ & $\mathrm{COPh}$ & $-0.139 /-0.172[-0.0215]$ & $-0.124 /-0.131[+0.0065]$ & $-0.134[0]$ \\
\hline & h & $\mathrm{CN}$ & $-0.121[+0.013]$ & $-0.127[+0.007]$ & $-0.133[+0.001]$ \\
\hline & $\mathbf{i}$ & $\mathrm{CO}_{2} \mathrm{Me}$ & $-0.140 /-0.141[-0.0065]$ & $-0.128 /-0.130[+0.005]$ & $-0.135[-0.001]$ \\
\hline & $\mathbf{m}$ & $\mathrm{F}$ & $-0.190[-0.056]$ & $-0.135[-0.001]$ & $-0.139[-0.005]$ \\
\hline
\end{tabular}

a) $\Delta$ Mulliken $=$ Mulliken charge of the substituted ferrocene - Mulliken charge of bare ferrocene.

Table 5. Carbon Mulliken charges calculated for the corresponding deiodinated benzenes.

\begin{tabular}{|c|c|c|c|c|c|}
\hline \multirow{2}{*}{ Substrate } & & \multirow{2}{*}{$\mathrm{R}$} & \multicolumn{3}{|l|}{ Mulliken [ $\Delta$ Mulliken] $^{\text {a) }}$} \\
\hline & & & At C2 & At C3 & At C4 \\
\hline \multirow{9}{*}{${ }_{4}^{R} \frac{11}{4}$} & a & $\mathrm{H}$ & -0.129 & & \\
\hline & b & $\mathrm{Me}$ & $-0.179[-0.050]$ & $-0.127[+0.002]$ & $-0.133[-0.004]$ \\
\hline & $\mathbf{c}$ & $\mathrm{CH}_{2} \mathrm{NiPr}_{2}$ & $-0.166 /-0.188[-0.048]$ & $-0.131 /-0.128[-0.0005]$ & $-0.130[-0.001]$ \\
\hline & d & $\mathrm{CH}_{2} \mathrm{OMe}$ & $-0.162 /-0.179[-0.0415]$ & $-0.133 /-0.130[-0.0025]$ & $-0.128[+0.001]$ \\
\hline & $f$ & $\mathrm{CHO}$ & $-0.156 /-0.177[-0.0375]$ & $-0.131 /-0.132[-0.0025]$ & $-0.119[+0.010]$ \\
\hline & g & $\mathrm{COPh}$ & $-0.151 /-0.177[-0.035]$ & $-0.135 /-0.137[-0.0070]$ & $-0.119[+0.010]$ \\
\hline & h & $\mathrm{CN}$ & $-0.134[-0.005]$ & $-0.133[-0.004]$ & $-0.116[+0.013]$ \\
\hline & i & $\mathrm{CO}_{2} \mathrm{Me}$ & $-0.152 /-0.158[-0.026]$ & $-0.138 /-0.137[-0.0085]$ & $-0.117[+0.012]$ \\
\hline & $\mathbf{m}$ & $\mathrm{F}$ & $-0.195[-0.066]$ & $-0.130[-0.001]$ & $-0.130[-0.001]$ \\
\hline
\end{tabular}

a) $\Delta$ Mulliken = Mulliken charge of the substituted benzene - Mulliken charge of bare benzene.

The Mulliken charges on carbons for the corresponding deiodinated benzenes were similarly calculated for comparison purpose (Table 5). As before, introducing remote substituents at C3 and C4 has a limited impact on the electron-rich character of the phenyl group; however, the same substituents fixed at C2 exert in general a stronger effect, making the 2-substituted phenyls more electron-rich, and thus more able to disfavor reductive elimination. As the substituent effect is even less pronounced in the ferrocene series, reductive elimination as determining step is less likely.

This analysis of the reaction yields as a function of both the substituent and its position onto ferrocene shows that reaction conditions cannot be simply transposed from halogenated benzenes to the corresponding ferrocenes. This access to $N$ ferrocenyl amides highly depends on the nature and, to a lesser extent, on the position of the substituent (e.g. amino groups) onto the iodinated partner, and this behavior strongly differs from the benzene series. Indeed, similar couplings between amides and iodobenzenes bearing for example 3- $\mathrm{CH}_{2} \mathrm{OH}$, 3-COMe, 3-CN, 4CONHR and $4-\mathrm{CO}_{2} \mathrm{R}$ can be carried out in good yields. ${ }^{[10]}$ However, when more elaborated aryl iodides ${ }^{[3,6-7,9,33]}$ or iodinated heteroaromatics ${ }^{[8,34]}$ are similarly reacted with amides, lower yields are more commonly obtained.

\section{Evidence toward unlikely radical pathway}

In the frame of studies dedicated to the mechanism of the copper-catalyzed $\mathrm{N}$-arylation of amides, authors tried to use radical clocks such as 1-allyloxy-2-iodobenzene as substrate. ${ }^{[11 \mathrm{c}, 20 \mathrm{a}]}$ However, they never observed any traces of cyclized product that could evidence the involvement of radical species. For this reason, they discarded a radical pathway in spite of observed protodeiodation (which is often a side reaction in Ullmann couplings). [20a] Protodeiodation side reactions were noticed previously by Cohen ${ }^{[35]}$ and Hartwig[11c] in similar reactions, and even by reacting generated aryl-Cu(III) complexes. ${ }^{[20 \mathrm{~b}]}$ We also observed protodeiodation in our experiments, for example in the case of iodoferrocenes substituted by electron-withdrawing groups such as $\mathrm{CHO}, \mathrm{COPh}$, $\mathrm{CN}$ and $\mathrm{CO}_{2} \mathrm{Me}$, but also with $\mathrm{NHCO}_{2} \mathrm{tBu}$. By coupling acetamide with iodoferrocene (1a) as in Scheme 1, but in the presence of 2,2,6,6-tetramethyl-1-piperidyloxy (TEMPO; 1 equiv) as additive in order to intercept a putative radical, the expected product $2 \mathbf{2 a}$ was formed in a moderate $33 \%$ yield. While a careful purification of the crude did not yield any TEMPO derivative, bare ferrocene was isolated in 59\% yield without recovery of starting material 1a, explaining why the reaction stopped. Interestingly, by carrying out our reference reaction (Scheme 1) without acetamide, ferrocene was only formed in $2 \%$ yield while $85 \%$ of the starting iodoferrocene (1a) was recovered; this result shows that the amide plays a role in this protodeiodation. Similarly, without acetamide but in the presence of TEMPO (1 equiv), no ferrocene was obtained and 1 a was recovered in $88 \%$ yield, indicating that 
the amide is required in this protodeiodation. Finally, simply heating 1a with TEMPO in dioxane at $90{ }^{\circ} \mathrm{C}$ for $14 \mathrm{~h}$ only provided recovered $1 \mathrm{a}$, isolated in $92 \%$ yield. Therefore, all these results tend to indicate that protodeiodation takes place from the arylcopper(III) intermediate, formed by reversible oxidative addition of the $\mathrm{C}-\mathrm{I}$ bond to copper $(\mathrm{I})^{[20 \mathrm{~b}]}$ through protonation by the amide. The reason why TEMPO favors protodeiodation might be a participation in the arylcopper(III) intermediate, disfavoring reductive elimination.

In a last attempt to intercept a putative ferrocenyl radical, we considered a radical cyclization reaction using indole as radical acceptor. ${ }^{[36]}$ To that end, the 2-substituted iodoferrocene $1 \mathrm{n}$ was treated with tributyltin hydride in the presence of azobisisobutyronitrile (AIBN) in toluene at $115^{\circ} \mathrm{C}$. However, after $36 \mathrm{~h}$ under these conditions, only traces of a cyclized product were detected while $59 \%$ of the starting 1 n were recovered.

Finally, amidation of $\mathbf{1 n}$ by 2-pyrrolidinone (which is an efficient amide partner for such couplings ${ }^{[2]}$ gave the expected derivative $\mathbf{2 n}$, isolated in $11 \%$ yield, and $80 \%$ of recovered $\mathbf{1 n}$ (Scheme 3). This low yield led us to attempt our reference coupling reaction (Scheme 1) between iodoferrocene (1a) and acetamide in the presence of $\mathrm{N}$-methylindole (1 equiv) to see if this electron-rich moiety can impact the course of the reaction. As suspected, the coupling product $\mathbf{2 a}$ was only isolated in a moderate $28 \%$ yield under these conditions while $52 \%$ of starting 1 a was recovered, indicating that $N$-methylindole can jeopardize the result of the coupling reaction. Note that deiodination was not observed at all in both reactions.

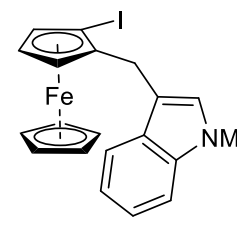

1n

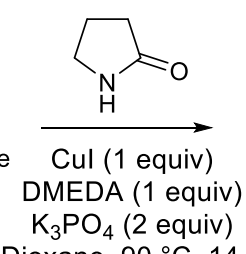

Dioxane, $90{ }^{\circ} \mathrm{C}, 14 \mathrm{~h}$

$(11 \%$ yield $)$

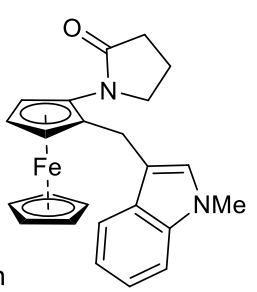

2n
Scheme 3. Reaction from $1 \mathrm{n}$

\section{Specific solid-state structures of the ferrocene amides}

In the course of this study, crystals suitable for X-ray diffraction analysis were obtained for some of the prepared acetamidoferrocene derivatives and revealed interesting differences between isomers at the solid state. Concerning the methyl-substituted compounds $\mathbf{2} \mathbf{b}$ (Figure 1 , top) and $\mathbf{6 b}$ (Figure 1 , bottom), while two molecules were found in the asymmetric unit of both compounds, the angles between the acetamide and the $\mathrm{Cp}$ ring were found different. Indeed, moving the methyl group from the 1'-position (angles of 17.7 and $23.8^{\circ}$ for compound $\mathbf{6 b}$ ) forces the acetamide moiety to rotate (angles of 54.1 and $56.5^{\circ}$ for compound $\mathbf{2 b}$ ) probably for steric reasons. Different hydrogen bonds networks were also identified as only one string of hydrogen bonds links the acetamide groups in compound $\mathbf{2} \mathbf{b}$ while two parallel strings of hydrogen bonds going in the same direction were observed in compound $\mathbf{6 b}$.
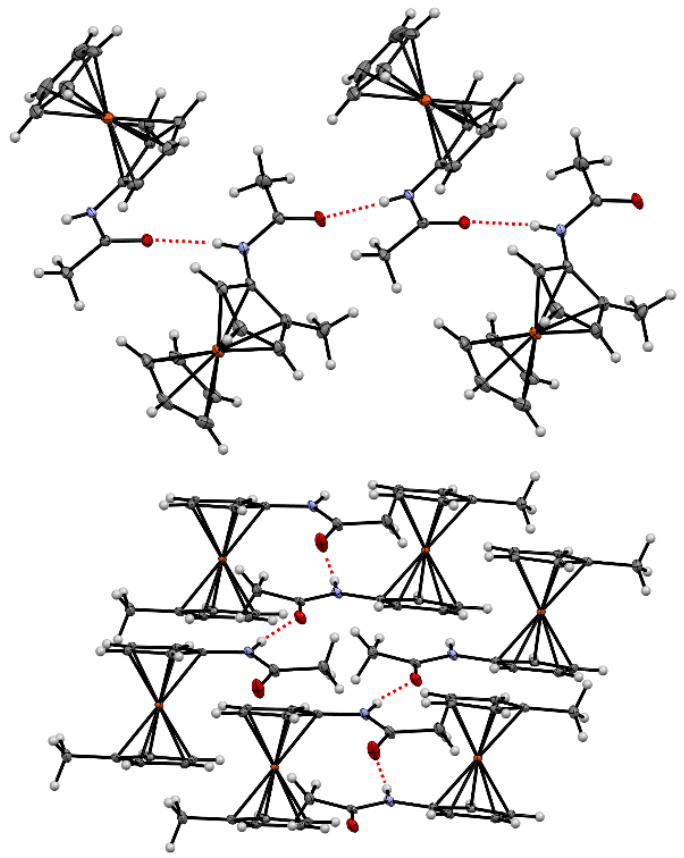

Figure 1. Hydrogen bonds network observed at the solid state for compounds $\mathbf{2 b}$ (top) and $\mathbf{6 b}$ (bottom). Thermal ellipsoids shown at the $30 \%$ probability level.

Similar differences were also observed for the solid-state structures of the 2- and 3-substituted acetamidoferrocenes $2 \mathbf{i}$ and $\mathbf{4 i}$, respectively. In the later, the acetamide is bent upward, as usually observed $\left(21.9\right.$ and $25.7^{\circ}$ angles for the two molecules found in the asymmetric unit), and engaged in a hydrogen bonds network which links the acetamide and the ester moieties with an additional water molecule which co-crystallized (Figure 2).

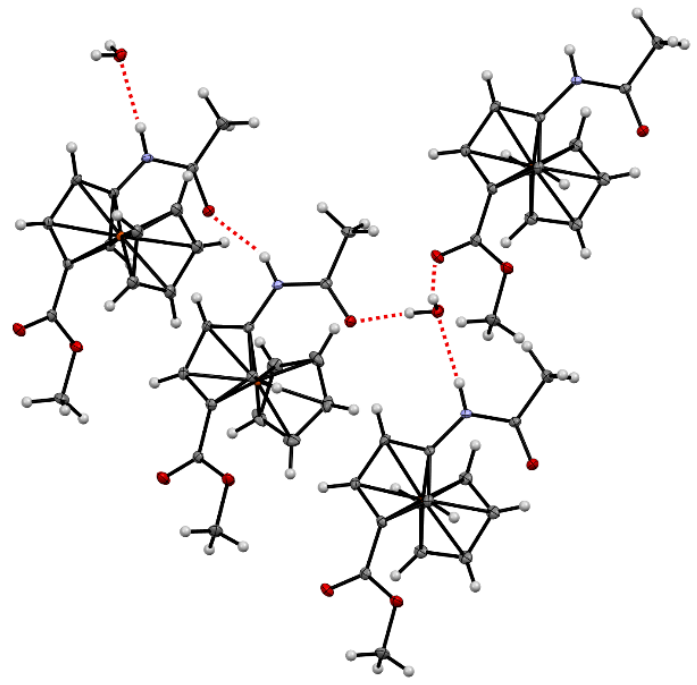

Figure 2. Hydrogen bonds network observed at the solid state for compound 4i. Thermal ellipsoids shown at the $30 \%$ probability level. 

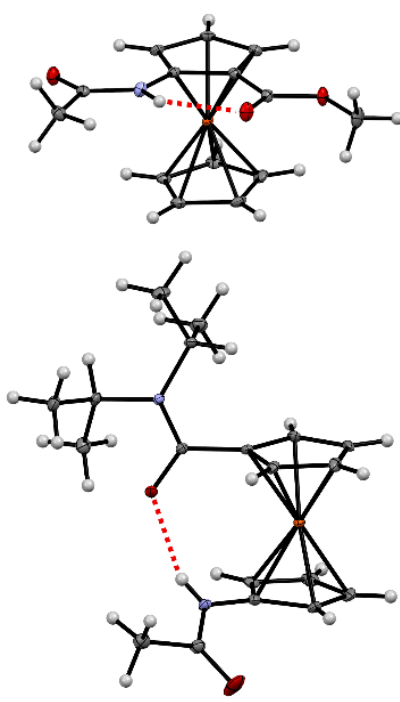

Figure 3. Hydrogen bonds observed at the solid state for compounds $\mathbf{2} \mathbf{i}$ (top) and $6 \mathbf{j}$ (bottom). Thermal ellipsoids shown at the $30 \%$ probability level.

On the contrary, due to the proximity between the two functional groups in compound $\mathbf{2} \mathbf{i}$, an intramolecular hydrogen bond between the ester and the acetamide forces the later to be almost coplanar with the $\mathrm{Cp}$ ring $\left(1.2^{\circ}\right.$ angle; Figure 3 , top). Similarly, an intramolecular hydrogen bond between the acetamide and the $\mathrm{N}, \mathrm{N}$-diisopropylcarboxamide moiety of compound 6j was observed at the solid state (Figure 3, bottom). Consequently, the $\mathrm{C}=\mathrm{O}$ bonds of the two groups point downward with respectively 40.1 and $52.7^{\circ}$ angles between the acetamide and $\mathrm{N}, \mathrm{N}$-diisopropylcarboxamide and their linked $\mathrm{Cp}$ ring.

However, moving one substituent from the 1'-position of compound $\mathbf{6 j}$ to the 3-position with compound $\mathbf{4 j}$ has a profound impact on the solid-state structure. Indeed, while the free rotating $\mathrm{Cp}$ cycles allow the intramolecular hydrogen bond observed in 6j, having both substituents on the same cycle favors intermolecular hydrogen bonds as observed at the solid state (Figure 4). This results in the formation of a crystalline tetramer linked by four hydrogen bonds between the acetamide and the $\mathrm{N}, \mathrm{N}$-diisopropylcarboxamide. Furthermore, as compound $\mathbf{4 j}$ was obtained as a racemic mixture, one can notice that two opposite molecules of the tetramer are enantiomers.

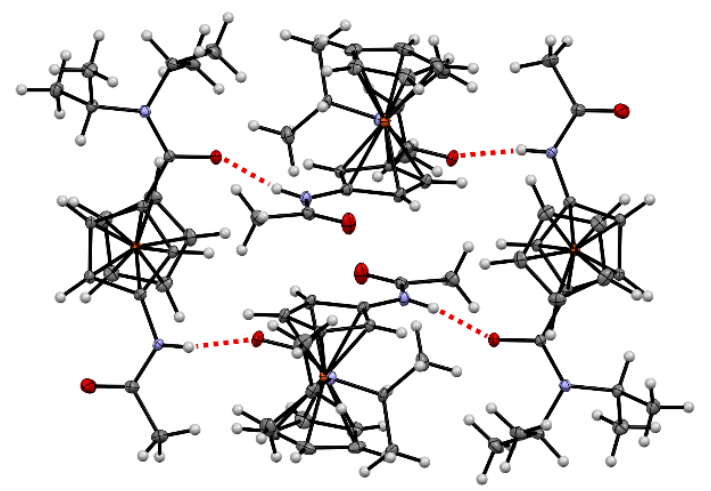

Figure 4. Hydrogen bonds observed at the solid state for compounds $\mathbf{4 j}$. Thermal ellipsoids shown at the $30 \%$ probability level.

\section{Conclusion}

In the present study, we highlighted both the reactivity (in the copper-mediated $\mathrm{N}$-ferrocenylation of acetamide) and the structural differences that can exist between the different isomeric substituted ferrocenes. While a large range of original $\mathrm{N}$-ferrocenyl acetamides were obtained (only 3 of them were known before over the 31 here prepared) and could be included in molecular designs, we tried to rationalize their corresponding yields in terms of electronic and structural features in order to understand the impact of the substituents and their position. Although approaches are able to predict the aryl iodide activation, we evidenced the need, in the ferrocene series, for more specific predictive tools considering (i) steric hindrance inherent to the 3 $D$ ferrocene structure (prediction was right in the case of the small fluoro group) and (ii) possible coordination to copper of some of the tested substituents. Indeed, as iodoferrocenes are less activated substrates than iodobenzenes, their substituents play an important role upon involvement in copper-catalyzed C$\mathrm{N}$ bond formation.

\section{Experimental Section}

General Considerations. All the reactions were performed under an argon atmosphere and by using anhydrous solvents in dried Schlenk tubes. Column chromatography separations were achieved on silica gel (40-63 $\mu \mathrm{m})$. Melting points were measured on a Kofler bench. IR spectra were taken on a Perkin-Elmer Spectrum 100 spectrometer. ${ }^{1} \mathrm{H}$ and ${ }^{13} \mathrm{C}$ Nuclear Magnetic Resonance (NMR) spectra were recorded either (a) on a Bruker Avance III spectrometer at $300 \mathrm{MHz}$ and $75 \mathrm{MHz}$, respectively, or (b) on a Bruker Avance III HD at $400 \mathrm{MHz}$ and $100 \mathrm{MHz}$, respectively, or (c) on a Bruker Avance III HD at $500 \mathrm{MHz}$ and $126 \mathrm{MHz}$, respectively. ${ }^{1} \mathrm{H}$ chemical shifts $(\delta)$ are given in ppm relative to the solvent residual peak and ${ }^{13} \mathrm{C}$ chemical shifts are relative to the central peak of the solvent signal. ${ }^{[37]}$

Dioxane was distilled over $\mathrm{CaH}_{2}$. lodoferrocene (1a), ${ }^{[17,38]} 2$ iodoferrocenecarboxylic acid, ${ }^{[17]}$ 1-iodo-3/1'-methylferrocenes $\left(\mathbf{3 b}^{[19 i]}\right.$ and $\left.\mathbf{5}^{[19 j]}\right)$, 1-(diisopropylaminomethyl)-3/1'iodoferrocenes $\quad\left(3 \mathbf{c}^{[19 a]}\right.$ and $\left.\mathbf{5} \mathbf{c}^{[19 \mathrm{j}]}\right)$, 1-iodo-3/1' (methoxymethyl)ferrocenes $\left(\mathbf{3 d}^{[19 i]}\right.$ and $\left.5 \mathbf{d}^{[19 j]}\right), 3 / 1^{\prime}-$ iodoferrocenemethanols $\left(3 \mathrm{e}^{[19 \mathrm{i}]}\right.$ and $\left.5 \mathrm{e}^{[19 \mathrm{j}]}\right), \quad 3 / 1^{\prime}$ iodoferrocenecarboxaldehydes $\left(\mathbf{3}^{[19 i]}\right.$ and $\left.\mathbf{5 f}^{[19 j]}\right),\left(3 / 1^{\prime}\right.$ iodoferrocenyl)phenylketones $\left(\mathbf{3 g}^{[19 i]}\right.$ and $\left.5 \mathbf{g}^{[19 j]}\right), 2 / 3 / 1^{\prime}-$ iodoferrocenecarbonitriles $\left(\mathbf{1} \mathbf{h},{ }^{[25]} \mathbf{3} \mathbf{h}^{[19 i]}\right.$ and $\left.\mathbf{5} \mathbf{h}^{[19 j]}\right)$, methyl $3 / 1^{\prime}$ iodoferrocenecarboxylates $\left(3 i^{[19 i]}\right.$ and $\left.5 i^{[19 j]}\right), 2 / 3 / 1^{\prime}$-iodo- $N, N$ diisopropylferrocenecarboxamides $\left(\mathbf{1} \mathbf{j}^{[19 a]} \mathbf{3} \mathbf{j}^{[19 a]}\right.$ and $\left.\mathbf{5} \mathbf{j}^{[19 \mathrm{j}]}\right)$, $2 / 3 / 1^{\prime}$-iodo- $N, N$-dimethylferrocenamines $\quad\left(\mathbf{1} \mathbf{k}^{[26]} \quad \mathbf{3} \mathbf{k}^{[19 i]}\right.$ and $\left.\mathbf{5 k}^{[19 j]}\right), N$-(tert-butoxycarbonyl)-3/1'-iodoferroceneamines (3[ ${ }^{[19 i]}$ and $\mathbf{5}^{\left[{ }^{19 j]}\right)}$, and 1-fluoro-2/3-iodoferrocenes $\left(\mathbf{1 m}^{[19 \mathrm{c}]}\right.$ and $\left.\mathbf{3} \mathbf{m}^{[19 \mathrm{~g}]}\right)$ were prepared as described previously.

Crystallography. The X-ray diffraction data were collected for the compounds $\mathbf{2} \mathbf{b}, \mathbf{6 b}, \mathbf{6 f}, \mathbf{2 i}, \mathbf{4 i}, \mathbf{4 j}$ and $\mathbf{6 j}$ at 150 (2) $\mathrm{K}$ on a D8 VENTURE Bruker AXS diffractometer equipped with a (CMOS) PHOTON 100 detector by using Mo-K $\square$ radiation ( $\square=0.71073$ $\AA$; multilayer monochromator). The structures were solved by dual-space algorithm using the SHELXT program, ${ }^{[39]}$ and then refined with full-matrix least-square methods based on $F^{2}$ $(S H E L X L){ }^{[40]}$ All non-hydrogen atoms were refined with anisotropic atomic displacement parameters. Except hydrogen atoms linked to nitrogen atoms that were introduced in the structural model through Fourier difference maps analysis, $\mathrm{H}$ atoms were finally included in their calculated positions and treated as riding on their parent atom with constrained thermal parameters. The molecular diagrams were generated by ORTEP-3 (version 2.02). ${ }^{[41]}$

1-(N,N-Diisopropylaminomethyl)-2-iodoferrocene (1c, racemic mixture). The protocol was adapted from a previously reported 
procedure. ${ }^{[42]}$ To a stirred solution of 2-iodo- $N, N$ diisopropylferrocenecarboxamide ${ }^{[19 a]}(\mathbf{1 j}, 6.8 \mathrm{mmol}, 3.0 \mathrm{~g})$ in THF $(70 \mathrm{~mL})$ under argon was added $\mathrm{BH}_{3}$. THF $(34 \mathrm{mmol}, 34 \mathrm{~mL}$ of a $1.0 \mathrm{M}$ solution). The mixture was refluxed for $16 \mathrm{~h}$, cooled to room temperature, quenched by $10 \%$ aqueous $\mathrm{KOH}(35 \mathrm{~mL})$ and refluxed for $10 \mathrm{~h}$. The resulting solution was cooled to room temperature. Brine $(50 \mathrm{~mL})$ was added before extraction with $\mathrm{Et}_{2} \mathrm{O}(3 \times 20 \mathrm{~mL})$, drying over $\mathrm{MgSO}_{4}$, concentration under reduced pressure, and purification by chromatography over silica gel (eluent: heptane-AcOEt 60:40 to 0:100). The compound 1c was isolated in $72 \%$ yield as an orange oil: IR (ATR): 805, 819, 953, 1000, 1106, 1151, 1181, 1203, 1361, 1381 $1461,1676,2961 \mathrm{~cm}^{-1} ;{ }^{1} \mathrm{H}$ NMR $\left(\mathrm{CDCl}_{3}\right) \delta 1.02(\mathrm{~d}, 6 \mathrm{H}, J=6.7$ $\mathrm{Hz}, 2 \mathrm{Me}$ ), 1.03 (d, $6 \mathrm{H}, J=6.7 \mathrm{~Hz}, 2 \mathrm{Me}$ ), 3.02 (sept, 2H, $J=6.7$ $\mathrm{Hz}, 2 \mathrm{CHMe}$ ), 3.39 (d, $1 \mathrm{H}, J=14.5 \mathrm{~Hz}, \mathrm{CHH}), 3.59$ (d, $1 \mathrm{H}, J=$ $14.5 \mathrm{~Hz}, \mathrm{CHH}), 4.11(\mathrm{~s}, 5 \mathrm{H}, \mathrm{Cp}), 4.14(\mathrm{t}, 1 \mathrm{H}, J=2.3 \mathrm{~Hz}, \mathrm{H} 4)$, $4.32(\mathrm{br} \mathrm{s}, 1 \mathrm{H}, \mathrm{H} 5), 4.38(\mathrm{dd}, 1 \mathrm{H}, J=2.3$ and $1.4 \mathrm{~Hz}, \mathrm{H} 3) ;{ }^{13} \mathrm{C}$ NMR $\left(\mathrm{CDCl}_{3}\right) \delta 20.6\left(2 \mathrm{CH}_{3}\right), 21.6\left(2 \mathrm{CH}_{3}\right), 44.6\left(\mathrm{CH}_{2}\right), 45.4(\mathrm{C}$, $\mathrm{C} 2, \mathrm{C}-\mathrm{I}), 47.3\left(2 \mathrm{CH}, \mathrm{CHMe}_{2}\right), 68.2(\mathrm{CH}, \mathrm{C} 4), 69.1(\mathrm{CH}, \mathrm{C} 5), 71.7$ $(5 \mathrm{CH}, \mathrm{Cp}), 74.1(\mathrm{CH}, \mathrm{C} 3), 89.4\left(\mathrm{C}, \mathrm{C} 1, \mathrm{C}_{-} \mathrm{CH}_{2}\right) ; \mathrm{MS}(\mathrm{El}, 70 \mathrm{eV})$ : $425[\mathrm{M}], 325$ [M-NiPr 2$]$. 1-lodo-2-methylferrocene (1b, racemic mixture) also formed and was similarly isolated in $18 \%$ yield as an orange oil: IR (ATR): 802, 818, 941, 989, 1000, 1030, 1105, $1362,1380,1454,2916,3092 \mathrm{~cm}^{-1} ;{ }^{1} \mathrm{H}$ NMR $\left(\mathrm{CDCl}_{3}\right) \delta 2.02(\mathrm{~s}$, $3 \mathrm{H}, \mathrm{Me}$ ), $4.10(\mathrm{~s}, 6 \mathrm{H}, \mathrm{Cp}$ and $\mathrm{H} 4), 4.16(\mathrm{dd}, 1 \mathrm{H}, J=2.4$ and 1.4 $\mathrm{Hz}, \mathrm{H} 3$ ), 4.35 (dd, $1 \mathrm{H}, J=2.4$ and $1.4 \mathrm{~Hz}, \mathrm{H} 5) ;{ }^{13} \mathrm{C} \mathrm{NMR}\left(\mathrm{CDCl}_{3}\right)$ $\delta 15.9\left(\mathrm{CH}_{3}\right), 46.6(\mathrm{C}, \mathrm{C} 1, \mathrm{C}-\mathrm{I}), 67.8(\mathrm{CH}, \mathrm{C} 4), 68.1(\mathrm{CH}, \mathrm{C} 3)$, 71.7 (5CH, Cp), 73.9 (CH, C5), 86.0 (C, C2, C-Me); MS (El, 70 $\mathrm{eV}): 326[\mathrm{M}]$. The spectral data are similar to those reported previously. ${ }^{[43]}$

2-lodoferrocenecarboxaldehyde (1f, racemic mixture) was prepared as described previously under the exclusion of light. ${ }^{[25]}$ It was obtained (eluent: heptane- $\mathrm{CH}_{2} \mathrm{Cl}_{2}-\mathrm{Et}_{3} \mathrm{~N}$ 75:15:10) as a red oil: IR (ATR) 747, 817, 953, 1002, 1107, 1247, 1363, 1394, 1431, $1665,2763,2835,2922,3096 \mathrm{~cm}^{-1} ;{ }^{1} \mathrm{H}$ NMR $\left(\mathrm{CDCl}_{3}\right) \delta 4.28(\mathrm{~s}$, $5 \mathrm{H}, \mathrm{Cp}), 4.69(\mathrm{t}, 1 \mathrm{H}, J=2.4 \mathrm{~Hz}, \mathrm{H} 4), 4.83(\mathrm{dd}, 1 \mathrm{H}, J=2.2$ and $1.2 \mathrm{~Hz}, \mathrm{H} 3$ ), 4.90 (dd, $1 \mathrm{H}, J=2.4$ and $1.2 \mathrm{~Hz}, \mathrm{H} 5), 10.04(\mathrm{~s}, 1 \mathrm{H}$, $\mathrm{CHO}) ;{ }^{13} \mathrm{C}$ NMR $\left(\mathrm{CDCl}_{3}\right) \& 42.0$ (C, C2, C-I), 67.9 (CH, C5), 72.8 (5CH, Cp), $73.9(\mathrm{CH}, \mathrm{C} 4), 76.9(\mathrm{C}, \mathrm{C} 1, \mathrm{C}-\mathrm{CHO}), 79.8(\mathrm{CH}, \mathrm{C} 3)$, 194.7 (CHO); MS (El, $70 \mathrm{eV}): 340$ [M], 212 [M-HI]. These data are similar to those reported previously. ${ }^{[25]}$

(2-lodoferrocenyl)phenylketone (1g, racemic mixture) was prepared as reported previously.[25] It was isolated (eluent: heptane-AcOEt 90:10) as a red oil: IR (ATR) 721, 796, 824, 857, 910, 985, 1001, 1026, 1046, 1065, 1107, 1156, 1175, 1190, 1250 (s), 1316, 1352, 1370, 1418, 1446, 1576, 1597, 1641 (s), 2247, $3087 \mathrm{~cm}^{-1} ;{ }^{1} \mathrm{H}$ NMR $\left(\mathrm{CDCl}_{3}\right) \delta 4.24(\mathrm{~s}, 5 \mathrm{H}, \mathrm{Cp}), 4.53(\mathrm{t}, 1 \mathrm{H}$, $J=2.4 \mathrm{~Hz}, \mathrm{H} 4), 4.62(\mathrm{dd}, 1 \mathrm{H}, J=2.4$ and $1.4 \mathrm{~Hz}, \mathrm{H} 5), 4.85(\mathrm{dd}$, $1 \mathrm{H}, J=2.4$ and $1.4 \mathrm{~Hz}, \mathrm{H} 3), 7.45$ (t, $2 \mathrm{H}, J=7.4 \mathrm{~Hz}, \mathrm{H} 3^{\prime}$ and $\mathrm{H}^{\prime}$ ), $7.56\left(\mathrm{t}, 1 \mathrm{H}, J=7.4 \mathrm{~Hz}, \mathrm{H} 4{ }^{\prime}\right), 7.85(\mathrm{~d}, 2 \mathrm{H}, J=7.4 \mathrm{~Hz}, \mathrm{H} 2$ ' and $\left.\mathrm{H} 6^{\prime}\right) ;{ }^{13} \mathrm{C}$ NMR $\left(\mathrm{CDCl}_{3}\right) \delta 41.1(\mathrm{C}, \mathrm{C} 2, \mathrm{C}-\mathrm{I}), 71.6(\mathrm{CH}, \mathrm{C} 5), 72.5$ $(\mathrm{CH}, \mathrm{C} 4), 73.4(5 \mathrm{CH}, \mathrm{Cp}), 77.8(\mathrm{C}, \mathrm{C} 1, \mathrm{C}-\mathrm{C}(=\mathrm{O}) \mathrm{Ph}), 80.2(\mathrm{CH}$, C3), $128.3\left(2 \mathrm{CH}, \mathrm{C}^{\prime}\right.$ ' and $\left.\mathrm{C}^{\prime}\right), 128.8\left(2 \mathrm{CH}, \mathrm{C} 2\right.$ ' and ' $\left.66^{\prime}\right), 132.1$ ( $\left.\mathrm{CH}, \mathrm{C}^{\prime}\right), 139.3$ (C, C1', C-C(=O)Fc), 197.9 (C, C=O). The analyses are similar to those reported previously. ${ }^{[25]}$

2-lodoferrocenecarbonitrile (1h, racemic mixture) was prepared as reported previously. ${ }^{[25]}$ After purification by column chromatography over silica gel (eluent: hexane-AcOEt 98:2), it was obtained as an orange solid: $\mathrm{mp} 134-135^{\circ} \mathrm{C}$; IR (ATR) 817 , $827,846,948,999,1030,1106,1239,1362,1378,1409,2227$ (s), $3111 \mathrm{~cm}^{-1} ;{ }^{1} \mathrm{H}$ NMR $\left(\mathrm{CDCl}_{3}\right) \delta 4.35$ (s, 5H, Cp), 4.41 (t, $J=$ $2.6 \mathrm{~Hz}, \mathrm{H} 4), 4.65$ (dd, $J=2.6$ and $1.2 \mathrm{~Hz}, \mathrm{H} 3$ ), 4.71 (dd, $J=2.6$ and $1.2 \mathrm{~Hz}, \mathrm{H} 5) ;{ }^{13} \mathrm{C} \mathrm{NMR}\left(\mathrm{CDCl}_{3}\right) \delta 41.6$ (C, C2, C-I), 59.2 (C, C1, C-CN), $71.7(\mathrm{CH}, \mathrm{C} 4), 72.1(\mathrm{CH}, \mathrm{C} 5), 73.7(5 \mathrm{CH}, \mathrm{Cp}), 77.4$ $(\mathrm{CH}, \mathrm{C} 3), 119.5(\mathrm{C}, \mathrm{C} \equiv \mathrm{N})$; MS (El, $70 \mathrm{eV}): 337$ [M], 209 [M-HI]. The NMR data are similar to those reported previously. ${ }^{[25]}$

Methyl 2-iodoferrocenecarboxylate (1i, racemic mixture) was prepared as reported previously. ${ }^{[25]}$ It was isolated (eluent: heptane-AcOEt 80:20) as an orange oil: IR (ATR) 770, 790, 822, 908, 992, 1058, 1106, 1144, 1191, 1254, 1272, 1328, 1370, 1418, 1445, 1707, 2948, $3097 \mathrm{~cm}^{-1} ;{ }^{1} \mathrm{H}$ NMR $\left(\mathrm{CDCl}_{3}\right) \delta 3.84(\mathrm{~s}$, $3 \mathrm{H}, \mathrm{Me}), 4.21(\mathrm{~s}, 5 \mathrm{H}, \mathrm{Cp}), 4.43(\mathrm{~s}, 1 \mathrm{H}, \mathrm{H} 4), 4.69(\mathrm{~s}, 1 \mathrm{H}, \mathrm{H} 3), 4.84$ (s, $1 \mathrm{H}, \mathrm{H} 5) ;{ }^{13} \mathrm{C}$ NMR $\left(\mathrm{CDCl}_{3}\right) \delta 39.8(\mathrm{C}, \mathrm{C} 2, \mathrm{C}-\mathrm{l}), 51.7\left(\mathrm{CH}_{3}\right)$, $70.3(\mathrm{CH}, \mathrm{C} 5), 71.1\left(\mathrm{C}, \mathrm{C} 1, \mathrm{C}-\mathrm{CO}_{2} \mathrm{Me}\right), 72.3(\mathrm{CH}, \mathrm{C} 4), 72.9(5 \mathrm{CH}$,
Cp), 79.8 ( $\mathrm{CH}, \mathrm{C} 3), 170.8(\mathrm{C}, \mathrm{C}=0)$; MS (El, $70 \mathrm{eV}): 370$ [M]. The NMR data are similar to those reported previously. ${ }^{[25]}$

2-lodoferrocenemethanol (1e, racemic mixture). The protocol was adapted from a previously reported procedure. ${ }^{[4]}$ To a stirred solution of methyl 2-iodoferrocenecarboxylate $(\mathbf{1 i} ; 1.85 \mathrm{~g}$, $5.0 \mathrm{mmol})$ in THF $(20 \mathrm{~mL})$ at $0{ }^{\circ} \mathrm{C}$ was added dropwise a $1.0 \mathrm{M}$ DIBAL-H solution in heptane $(20 \mathrm{~mL}, 20 \mathrm{mmol})$. The mixture was stirred at this temperature for $1 \mathrm{~h}$ before quenching by addition of $\mathrm{MeOH}(5 \mathrm{~mL})$, dilution with $\mathrm{Et}_{2} \mathrm{O}(50 \mathrm{~mL})$, and addition of an aqueous saturated solution of sodium and potassium tartrate (50 $\mathrm{mL}$ ) at $0{ }^{\circ} \mathrm{C}$. After stirring for $30 \mathrm{~min}$ at room temperature, extraction with $\mathrm{Et}_{2} \mathrm{O}$ and drying over anhydrous $\mathrm{Na}_{2} \mathrm{SO}_{4}$, the solvent was evaporated under reduced pressure, and purification by flash chromatography on silica gel (eluent: 88:12 heptane-AcOEt) gave the iodide $1 \mathrm{e}$ in $93 \%$ yield $(1.6 \mathrm{~g})$ : IR (ATR) $683,752,815,940,973,995,1061,1067,1103,1246,1309$, $1365,1385,1703,2857,2930,3089,3254 \mathrm{~cm}^{-1} ;{ }^{1} \mathrm{H}$ NMR $\left(\left(\mathrm{CD}_{3}\right)_{2} \mathrm{CO}\right) \delta 3.90(\mathrm{t}, 1 \mathrm{H}, J=5.9 \mathrm{~Hz}, \mathrm{OH}), 4.15(\mathrm{~s}, 5 \mathrm{H}, \mathrm{Cp}), 4.24$ $(\mathrm{t}, 1 \mathrm{H}, J=2.3 \mathrm{~Hz}, \mathrm{H} 5), 4.37(\mathrm{~s}, 1 \mathrm{H}, \mathrm{H} 3), 4.38-4.44(\mathrm{~m}, 3 \mathrm{H}, \mathrm{H} 4$ and $\left.\mathrm{CH}_{2}\right) ;{ }^{13} \mathrm{C}$ NMR $\left(\left(\mathrm{CD}_{3}\right)_{2} \mathrm{CO}\right) \delta 44.1(\mathrm{C}, \mathrm{C} 2, \mathrm{C}-\mathrm{I}), 61.2\left(\mathrm{CH}_{2}\right)$, $68.6(\mathrm{CH}, \mathrm{C} 3), 69.5(\mathrm{CH}, \mathrm{C} 5), 72.1(5 \mathrm{CH}, \mathrm{Cp}), 75.4(\mathrm{CH}, \mathrm{C} 4)$ $89.8\left(\mathrm{C}, \mathrm{C} 1, \mathrm{C}-\mathrm{CH}_{2} \mathrm{OH}\right)$; $\mathrm{MS}(\mathrm{El}, 70 \mathrm{eV}): 342$ [M], 138. These data are similar to those reported previously. ${ }^{[45]}$

1-lodo-2-(methoxymethyl)ferrocene (1d, racemic mixture). The protocol was adapted from a previously reported procedure. ${ }^{[46}$ 2-lodoferrocenemethanol (1e; $0.68 \mathrm{~g}, 2.0 \mathrm{mmol})$ was dissolved in a $4: 1 \mathrm{MeOH}-\mathrm{AcOH}$ mixture $(20 \mathrm{~mL})$, and the solution was heated under reflux for $2 \mathrm{~h}$ (complete conversion of the substrate). After evaporation, the crude was dissolved in methanol $(10 \mathrm{~mL})$. The solution was treated by $\mathrm{NaOH}(0.40 \mathrm{~g}$, $10 \mathrm{mmol}$ ) and heated under reflux in order to convert the acetate also formed into 2-iodoferrocenemethanol and separate it easily by chromatography over silica gel. The product $1 \mathbf{d}$ was obtained (eluent: 90:10 heptane-AcOEt) in 64\% yield as described previously ${ }^{[46]}$ as an orange oil. Alternatively, it can also be prepared by following this protocol: $\mathrm{NaH}(60 \%$ dispersion in oil, $72 \mathrm{mg}, 2.4 \mathrm{mmol})$ was added to a cooled $\left(0^{\circ} \mathrm{C}\right)$ solution of 2 iodoferrocenemethanol $(\mathbf{1 e} ; 0.27 \mathrm{~g}, 0.80 \mathrm{mmol})$ in THF $(5 \mathrm{~mL})$. After addition, the reaction mixture was warmed to rt and stirred for $1 \mathrm{~h}$. The reaction mixture was cooled to $0^{\circ} \mathrm{C}$, iodomethane $(0.34 \mathrm{~g}, 2.4 \mathrm{mmol})$ was added and the reaction mixture was stirred at $\mathrm{rt}$ for $1 \mathrm{~h}$. The reaction mixture was cooled to $0^{\circ} \mathrm{C}$ and aqueous saturated $\mathrm{NH}_{4} \mathrm{Cl}$ was added. The reaction mixture was extracted with AcOEt. The combined organic layer was dried over $\mathrm{MgSO}_{4}$, filtrated over cotton wool and concentrated under vacuum using a rotary evaporator to give the crude product. This was purified by purification by flash chromatography on silica gel (eluent: 88:12 heptane-AcOEt) to give the title product in a $89 \%$ yield: IR (ATR) 743, 807, 820, 900, 941, 1000, 1030, 1060, 1090, 1159, 1189, 1236, 1374, 1447, 1645, 2814, 2881, 2921, 2978, $3093 \mathrm{~cm}^{-1} ;{ }^{1} \mathrm{H} \mathrm{NMR}\left(\mathrm{CDCl}_{3}\right) \delta 3.36(\mathrm{~s}, 3 \mathrm{H}, \mathrm{Me}), 4.12(\mathrm{~s}, 5 \mathrm{H}, \mathrm{Cp})$, $4.24(\mathrm{t}, 1 \mathrm{H}, J=2.5 \mathrm{~Hz}, \mathrm{H} 4), 4.30(\mathrm{~d}, 1 \mathrm{H}, J=11.6 \mathrm{~Hz}, \mathrm{CH}), 4.32$ $4.34(\mathrm{~m}, 2 \mathrm{H}, \mathrm{H} 3$ and $\mathrm{CHH}), 4.46(\mathrm{br} \mathrm{s}, 1 \mathrm{H}, \mathrm{H} 5) ;{ }^{13} \mathrm{C} \mathrm{NMR}\left(\mathrm{CDCl}_{3}\right)$ $\delta 45.0(\mathrm{C}, \mathrm{C} 1, \mathrm{C}-\mathrm{I}), 58.2\left(\mathrm{CH}_{3}\right), 68.7(\mathrm{CH}, \mathrm{C} 3), 69.4(\mathrm{CH}, \mathrm{C} 4)$, $70.7\left(\mathrm{CH}_{2}\right), 71.5(5 \mathrm{CH}, \mathrm{Cp}), 75.3(\mathrm{CH}, \mathrm{C} 5), 84.7\left(\mathrm{C}, \mathrm{C} 2, \mathrm{C}-\mathrm{CH}_{2}\right)$ MS (EI, $70 \mathrm{eV}): 356[\mathrm{M}]$. These data are similar to those reported previously. ${ }^{[46]}$

1-Azidocarbonyl-2-iodoferrocene (racemic mixture) was prepared by adapting a reported procedure. ${ }^{[19 i]}$ Triethylamine $(2.8 \mathrm{~mL}, 20 \mathrm{mmol})$ was added to a solution of 2iodoferrocenecarboxylic acid $(1.4 \mathrm{~g}, 4.0 \mathrm{mmol})$ in dichloromethane $(5 \mathrm{~mL})$ at $40{ }^{\circ} \mathrm{C}$. Diphenyl Phosphoryl azide $(0.95 \mathrm{~mL}, 4.4 \mathrm{mmol})$ was next added dropwise to the reaction mixture which was then kept at the same temperature for $10 \mathrm{~min}$. The reaction mixture was cooled to room temperature and $1.0 \mathrm{M}$ aqueous hydrochloric acid $(20 \mathrm{~mL})$ was added. The reaction mixture was extracted with $\mathrm{Et}_{2} \mathrm{O}(2 \times 20 \mathrm{~mL})$ and the combined organic layers were dried over $\mathrm{MgSO}_{4}$, filtrated over cotton wool and concentrated under vacuum using a rotary evaporator to give the crude product. This was purified by column chromatography over silica gel (eluent: pentane- $\mathrm{Et}_{2} \mathrm{O}$ 80:20; $\mathrm{Rf}$ $=0.65)$ to give 1 -azidocarbonyl-2-iodoferrocene in $93 \%$ yield $(1.4$ g) as a red solid: $\mathrm{mp} 58-60^{\circ} \mathrm{C}$; IR (ATR) $667,739,752,820,895$, $1002,1011,1042,1079,1107,1122,1177$ (s), 1240, 1256, 1323 1352, 1370, 1386, 1424, 1685 (s), 2131 (s), 2198, 2263, 3099 $\mathrm{cm}^{-1} ;{ }^{1} \mathrm{H}$ NMR $\left(\mathrm{CDCl}_{3}\right) \delta 4.26(\mathrm{~s}, 5 \mathrm{H}, \mathrm{Cp}), 4.52(\mathrm{t}, 1 \mathrm{H}, J=2.7 \mathrm{~Hz}$ 
$\mathrm{H} 4)$, 4.80-4.81 (m, 2H, $\mathrm{H} 3$ and $\mathrm{H} 5) ;{ }^{13} \mathrm{C} \mathrm{NMR}\left(\mathrm{CDCl}_{3}\right) \delta 39.2$ (C, C2, C-I), $70.9(\mathrm{CH}, \mathrm{C} 3$ or $\mathrm{C} 5), 71.5\left(\mathrm{C}, \mathrm{C} 1, \mathrm{C}-\mathrm{CON}_{3}\right), 73.3(5 \mathrm{CH}$, $\mathrm{Cp}), 73.5(\mathrm{CH}, \mathrm{C} 4), 81.3(\mathrm{CH}, \mathrm{C} 3$ or $\mathrm{C} 5), 176.1(\mathrm{C}, \mathrm{C}=\mathrm{O})$.

1-(tert-Butoxycarbonylamino)-2-iodoferrocene (11, racemic mixture) was prepared by adapting a reported procedure. ${ }^{[19 i]}$ tertButanol $(1.35 \mathrm{~mL}, 14 \mathrm{mmol}$ ) was added to a solution of 1 azidocarbonyl-2-iodoferrocene $(1.0 \mathrm{~g}, 2.8 \mathrm{mmol})$ in toluene (23 $\mathrm{mL}$ ) at room temperature and the reaction mixture was heated at $110{ }^{\circ} \mathrm{C}$ for $1 \mathrm{~h}$. The reaction mixture was cooled to room temperature and volatiles were removed under reduced pressure. Purification by column chromatography over silica gel (eluent: petroleum ether-AcOEt $95: 5)$ gave $1 \mathrm{I}$ in $41 \%$ yield $(0.50$ g) as an orange solid: Rf (petroleum ether-AcOEt 95:5) = 0.40; mp $114-115^{\circ} \mathrm{C}$; IR (ATR) $668,690,772,810,827,874,978,999$ $1020,1049,1077,1104,1163,1254,1359$ (s), 1432, 1489, 1691 (s), 2970, $3249 \mathrm{~cm}^{-1} ;{ }^{1} \mathrm{H}$ NMR $\left(\mathrm{CDCl}_{3}\right) \delta 1.53(\mathrm{~s}, 9 \mathrm{H}, \mathrm{tBu}), 4.10$ (t, $1 \mathrm{H}, J=2.5 \mathrm{~Hz}, \mathrm{H} 4), 4.14(\mathrm{~s}, 5 \mathrm{H}, \mathrm{Cp}), 4.24$ (dd, $1 \mathrm{H}, J=2.3$ and $1.5 \mathrm{~Hz}, \mathrm{H} 3), 4.92(\mathrm{br} \mathrm{s}, 1 \mathrm{H}, \mathrm{H} 5), 5.75(\mathrm{br} \mathrm{s}, 1 \mathrm{H}, \mathrm{NH}) ;{ }^{13} \mathrm{C}$ NMR $\left(\mathrm{CDCl}_{3}\right) \delta 28.5\left(3 \mathrm{CH}_{3}, \mathrm{CMe}_{3}\right), 37.7(\mathrm{C}, \mathrm{C} 2, \mathrm{C}-\mathrm{I}), 60.2(\mathrm{CH}$, C5), $65.6(\mathrm{CH}, \mathrm{C} 4), 69.6(\mathrm{CH}, \mathrm{C} 3), 72.2(5 \mathrm{CH}, \mathrm{Cp}), 80.7$ (C, $\mathrm{CMe}_{3}$ ), 96.8 (C, C1, C-N), 153.2 (C, C=O); MS (El, $\left.70 \mathrm{eV}\right): 353$ $[\mathrm{M}-\mathrm{tBuO}+\mathrm{H}], 197$.

General procedure 1. The iodoferrocene (unless otherwise specified in the product description, $1.0 \mathrm{mmol})$, Cul $(0.19 \mathrm{~g}, 1.0$ $\mathrm{mmol}), \mathrm{K}_{3} \mathrm{PO}_{4}(0.42 \mathrm{~g}, 2.0 \mathrm{mmol})$, DMEDA $(0.11 \mathrm{~mL}, 1.0 \mathrm{mmol})$ and acetamide $(65 \mathrm{mg}, 1.1 \mathrm{mmol})$ were introduced in a degassed Schlenk tube and dissolved in dioxane $(2 \mathrm{~mL})$. The mixture was stirred under argon and heated at $90{ }^{\circ} \mathrm{C}$ for $14 \mathrm{~h}$. It was then allowed to cool to room temperature before addition of water (10 $\mathrm{mL})$. After extraction with AcOEt $(3 \times 20 \mathrm{~mL})$, drying over $\mathrm{MgSO}_{4}$ and evaporation of the solvent under reduced pressure, the coupling product was purified by chromatography over silica gel (the eluent is given in the product description).

$\mathrm{N}$-(2-Methylferrocenyl)acetamide (2b, stereoisomeric mixture due to rotamers). ${ }^{[47]}$ The general procedure 1 from 1-iodo-2methylferrocene $(\mathbf{1} \mathbf{b} ; 0.33 \mathbf{g})$ gave $\mathbf{2 b}$ (eluent: hexane-AcOEt $60: 40)$ in $61 \%$ yield $(0.16 \mathrm{~g})$ as an orange solid: $\mathrm{mp} 156-158^{\circ} \mathrm{C}$; IR (ATR) 800, 1001, 1029, 1103, 1270, 1282, 1368, 1482, 1545, $1646,2917,3046,3226 \mathrm{~cm}^{-1} ;{ }^{1} \mathrm{H}$ NMR $\left(\mathrm{CDCl}_{3}\right.$, * used for the minor compound) $\delta 1.79^{*}$ and $2.09(2 \mathrm{~s}, 3 \mathrm{H}, \mathrm{Me}-\mathrm{C}=\mathrm{O}), 1.95$ and $1.99^{\star}(2 \mathrm{~s}, 3 \mathrm{H}, \mathrm{Me}-\mathrm{Cp}), 3.94$ and $3.97^{\star}(2 \mathrm{~s}, 1 \mathrm{H}, \mathrm{H} 4), 4.00$ and $4.08^{*}(2 \mathrm{~s}, 1 \mathrm{H}, \mathrm{H} 3), 4.08$ and $4.11^{*}(2 \mathrm{~s}, 5 \mathrm{H}, \mathrm{Cp}), 4.22^{*}$ and 4.67 (2s, $1 \mathrm{H}, \mathrm{H} 5), 6.63$ and $6.95^{*}(2 \mathrm{br} \mathrm{s}, 1 \mathrm{H}, \mathrm{NH}) ;{ }^{13} \mathrm{C} \mathrm{NMR}\left(\mathrm{CDCl}_{3}\right.$, * used for the minor compound) $\delta 12.5^{\star}$ and $12.8\left(\mathrm{CH}_{3}, \mathrm{Me}-\mathrm{Cp}\right)$, $19.9^{*}$ and $24.0\left(\mathrm{CH}_{3}, \mathrm{Me}-\mathrm{C}=\mathrm{O}\right), 63.5$ and $66.9^{*}(\mathrm{CH}, \mathrm{C} 5), 63.5$ and $67.8^{*}(\mathrm{CH}, \mathrm{C} 4), 64.4^{*}$ and $66.6(\mathrm{CH}, \mathrm{C} 3), 69.9$ and $70.1^{*}$ (5CH, Cp), 77.3 and $81.6^{*}$ (C, C2, C-Me), 92.1* and 92.8 (C, C1, C-N), 169.1 and 174.6* (C, C=O); MS (El, $70 \mathrm{eV}): 257$ [M], 215 $\left[\mathrm{M}-\mathrm{CH}_{3} \mathrm{CO}+\mathrm{H}\right], 192$ [M-Cp]. Crystal data for $2 b . \mathrm{C}_{13} \mathrm{H}_{15} \mathrm{FeNO}, M$ $=257.11, T=150(2) \mathrm{K}$, triclinic, $P-1, a=8.9219(11), b=$ 11.5613(14), $c=12.0385(14) \AA, \alpha=69.424(4), \beta=82.673(5), y$ $=81.623(5){ }^{\circ}, V=1146.2(2) \AA^{3}, Z=4, d=1.490 \mathrm{~g} \mathrm{~cm}^{-3}, \mu=$ $1.292 \mathrm{~mm}^{-1}$. A final refinement on $F^{2}$ with 5243 unique intensities and 300 parameters converged at $\omega R\left(F^{2}\right)=0.1268(R(F)=$ 0.0506 ) for 4418 observed reflections with $I>2 \sigma(I)$. CCDC 2026533.

$\mathrm{N}$-(3-Methylferrocenyl)acetamide (4b, stereoisomeric mixture due to rotamers). The general procedure 1 from 1-iodo-3methylferrocene (3b; $0.33 \mathrm{~g}$ ) gave $\mathbf{4 b}$ (eluent: petroleum etherAcOEt $50: 50 ; \mathrm{Rf}=0.26)$ in $65 \%$ yield $(0.17 \mathrm{~g})$ as an orange oil: IR (ATR) 666, 751, 810, 928, 945, 968, 1000, 1030, 1105, 1138, $1200,1268,1285,1349,1374,1454,1491,1563,1651,2177$, 2922, 3093, $3269 \mathrm{~cm}^{-1} ;{ }^{1} \mathrm{H}$ NMR $\left(\mathrm{CDCl}_{3},{ }^{*}\right.$ used for the minor compound) $\delta 1.88$ and $1.94^{\star}(2 \mathrm{~s}, 3 \mathrm{H}, \mathrm{Me}-\mathrm{Cp}), 1.89^{\star}$ and 2.03 (2s, $3 \mathrm{H}, \mathrm{Me}-\mathrm{C}=\mathrm{O}), 3.94$ and $4.00^{*}(2 \mathrm{~s}, 1 \mathrm{H}, \mathrm{H} 4), 4.10$ and $4.12^{*}(2 \mathrm{~s}$, $5 \mathrm{H}, \mathrm{Cp}), 4.16^{*}$ and $4.43(2 \mathrm{~s}, 1 \mathrm{H}, \mathrm{H} 5), 4.21^{*}$ and $4.58(2 \mathrm{~s}, 1 \mathrm{H}$, $\mathrm{H} 2), 6.77$ (br s, $1 \mathrm{H}, \mathrm{NH}) ;{ }^{13} \mathrm{C} \mathrm{NMR}\left(\mathrm{CDCl}_{3},{ }^{*}\right.$ used for the minor compound) $\delta 14.8^{*}$ and $14.8\left(\mathrm{CH}_{3}, \mathrm{Me}-\mathrm{Cp}\right), 20.3^{*}$ and $24.1\left(\mathrm{CH}_{3}\right.$, $\mathrm{Me}-\mathrm{C}=\mathrm{O}), 60.8$ and $66.0^{*}(\mathrm{CH}, \mathrm{C} 5), 63.6$ and $68.1^{*}(\mathrm{CH}, \mathrm{C} 2)$, 65.6 and $67.2^{*}(\mathrm{CH}, \mathrm{C} 4), 70.1$ and $70.2^{*}(5 \mathrm{CH}, \mathrm{Cp}), 81.0$ and 82.5* (C, C3, C-Me), 92.3* and 94.2 (C, C1, C-N), 168.5 and $173.9^{*}(\mathrm{C}, \mathrm{C}=\mathrm{O}) ; \mathrm{MS}(\mathrm{EI}, 70 \mathrm{eV}): 257[\mathrm{M}], 215\left[\mathrm{M}-\mathrm{CH}_{3} \mathrm{CO}+\mathrm{H}\right]$, $192[\mathrm{M}-\mathrm{Cp}]$
$\mathrm{N}$-(1'-Methylferrocenyl)acetamide (6b). The general procedure 1 from 1 -iodo-1'-methylferrocene $(5 \mathrm{~b} ; 0.14 \mathrm{~g}, 0.43 \mathrm{mmol})$ gave $6 \mathrm{~b}$ (eluent: hexane-AcOEt $60: 40)$ in $80 \%$ yield $(90 \mathrm{mg}$ ) as an orange solid: $\mathrm{mp} 98-100^{\circ} \mathrm{C}$; IR (ATR) 746, 803, 1021, 1037, 1286, 1371 $1384,1477,1574,1652,2854,2921,3088,3212,3259 \mathrm{~cm}^{-1} ;{ }^{1} \mathrm{H}$ NMR $\left(\mathrm{CDCl}_{3}\right) \delta 1.95$ (s, 3H, Me-Fc), 2.05 (s, 3H, Me-C=O), 4.01 (s, 2H, H3 and $\mathrm{H} 4), 4.07$ (s, 2H, H3' and 'H4'), 4.10 (s, 2H, H2' and $\left.\mathrm{H}^{\prime}\right), 4.58(\mathrm{~s}, 2 \mathrm{H}, \mathrm{H} 2$ and $\mathrm{H} 5), 6.87(\mathrm{br} \mathrm{s}, 1 \mathrm{H}, \mathrm{NH}) ;{ }^{13} \mathrm{C} N M R$ $\left(\mathrm{CDCl}_{3}\right) \delta 13.9\left(\mathrm{CH}_{3}, \mathrm{Me}-\mathrm{Fc}\right), 24.1\left(\mathrm{CH}_{3}, M e-\mathrm{C}=\mathrm{O}\right), 62.0(2 \mathrm{CH}$, $\mathrm{C} 2$ and $\mathrm{C} 5), 65.6(2 \mathrm{CH}, \mathrm{C} 3$ and $\mathrm{C} 4), 68.6\left(2 \mathrm{CH}, \mathrm{C}^{\prime}\right.$ and $\left.\mathrm{C}^{\prime}\right)$, $70.6\left(2 \mathrm{CH}, \mathrm{C} 2\right.$ ' and $\mathrm{C}^{\prime}$ ), 85.5 (C, C1', C-Me), 96.1 (C, C1, C-N), $168.3(\mathrm{C}, \mathrm{C}=\mathrm{O})$; $\mathrm{MS}(\mathrm{El}, 70 \mathrm{eV}): 257[\mathrm{M}], 215\left[\mathrm{M}-\mathrm{CH}_{3} \mathrm{CO}+\mathrm{H}\right]$, 178. Crystal data for 6 b. $\mathrm{C}_{13} \mathrm{H}_{15}$ FeNO, $M=257.11, T=150(2) \mathrm{K}$, monoclinic, $P 2_{1}, a=5.9727(11), b=7.4595(14), c=25.351$ (4)

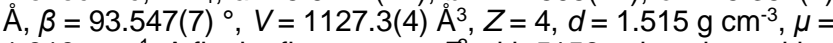
$1.313 \mathrm{~mm}^{-1}$. A final refinement on $F^{2}$ with 5158 unique intensities and 301 parameters converged at $\omega R\left(F^{2}\right)=0.0654(R(F)=$ 0.0261 ) for 4955 observed reflections with $l>2 \sigma(I)$. CCDC 2026534

$\mathrm{N}$-(3-(Diisopropylaminomethyl)ferrocenyl)acetamide

racemic mixture). The general procedure 1 from 1 (diisopropylaminomethyl)-3-iodoferrocene (3c; $0.21 \mathrm{~g}, \quad 0.50$ mmol) gave 4c (eluent: heptane-AcOEt- $\mathrm{Et}_{3} \mathrm{~N} \mathrm{59:40:1)}$ in $66 \%$ yield $(0.12 \mathrm{~g})$ as an orange oil: IR (ATR) $729,814,908,1001$ 1105, 1162, 1200, 1361, 1377, 1567, 1655, 2964, 3096, 3276 $\mathrm{cm}^{-1} ;{ }^{1} \mathrm{H}$ NMR $\left(\mathrm{CDCl}_{3}\right) \delta 0.99(\mathrm{~d}, 6 \mathrm{H}, \mathrm{J}=6.7 \mathrm{~Hz}, 2 \mathrm{Me}), 1.01(\mathrm{~d}$, $6 \mathrm{H}, J=6.7 \mathrm{~Hz}, 2 \mathrm{Me}$ ), 2.04 (s, 3H, Me-C=O), 3.05 (sept, $2 \mathrm{H}, J=$ $6.7 \mathrm{~Hz}, 2 \mathrm{CHMe}), 3.38(\mathrm{~d}, 1 \mathrm{H}, J=14.5 \mathrm{~Hz}, \mathrm{CH}), 3.44(\mathrm{~d}, 1 \mathrm{H}, J$ $=14.5 \mathrm{~Hz}, \mathrm{CHH}), 4.04(\mathrm{~s}, 1 \mathrm{H}, \mathrm{H} 4), 4.10(\mathrm{~s}, 5 \mathrm{H}, \mathrm{Cp}), 4.51(\mathrm{~s}, 1 \mathrm{H}$ $\mathrm{H} 5), 4.66(\mathrm{~s}, 1 \mathrm{H}, \mathrm{H} 2), 6.75(\mathrm{br} \mathrm{s}, 1 \mathrm{H}, \mathrm{NH}) ;{ }^{13} \mathrm{C} \mathrm{NMR}\left(\mathrm{CDCl}_{3}\right) \delta$ $20.8\left(2 \mathrm{CH}_{3}\right), 20.9\left(2 \mathrm{CH}_{3}\right), 24.2\left(\mathrm{CH}_{3}, M e-\mathrm{C}=\mathrm{O}\right), 44.2\left(\mathrm{CH}_{2}\right), 47.8$ $\left(2 \mathrm{CH}, \mathrm{CHMe}_{2}\right), 60.8(\mathrm{CH}, \mathrm{C5}), 63.1(\mathrm{CH}, \mathrm{C} 2), 65.9(\mathrm{CH}, \mathrm{C} 4)$ $69.8(5 \mathrm{CH}, \mathrm{Cp}), 84.6\left(\mathrm{C}, \mathrm{C} 3, \mathrm{C}-\mathrm{CH}_{2}\right), 94.1(\mathrm{C}, \mathrm{C} 1, \mathrm{C}-\mathrm{N}), 168.2$ $(\mathrm{C}, \mathrm{C}=\mathrm{O})$.

$N-(1 '-($ Diisopropylaminomethyl)ferrocenyl)acetamide (6c). The general procedure 1 from 1-(N,N-diisopropylaminomethyl)-1'iodoferrocene $(5 \mathrm{c} ; 0.22 \mathrm{~g}, 0.5 \mathrm{mmol})$ gave $6 \mathrm{c}$ (eluent: heptaneAcOEt $60: 40)$ in $52 \%$ yield $(90 \mathrm{mg})$ as an orange solid: $\mathrm{mp} 68$ $70{ }^{\circ} \mathrm{C}$; IR (ATR) 720, 805, 930, 1018, 1170, 1202, 1275, 1374 $1479,1553,1654,2961,3290 \mathrm{~cm}^{-1} ;{ }^{1} \mathrm{H}$ NMR $\left(\mathrm{CDCl}_{3}\right) \delta 0.99(\mathrm{~d}$ $12 \mathrm{H}, J=6.5 \mathrm{~Hz}, 4 \mathrm{Me}$ ), 2.06 (s, 3H, Me-C=O), 3.03 (sept, $2 \mathrm{H}, J$ $\left.=6.7 \mathrm{~Hz}, 2 \mathrm{C} \mathrm{HMe}_{2}\right), 3.42\left(\mathrm{~s}, 2 \mathrm{H}, \mathrm{CH}_{2}\right), 3.93(\mathrm{~s}, 2 \mathrm{H}, \mathrm{H} 3$ and $\mathrm{H} 4)$, 4.04 (s, 2H, H3' and $\mathrm{H}^{\prime}$ '), 4.16 (s, 2H, H2' and H5'), 4.51 (s, 2H, $\mathrm{H} 2$ and $\mathrm{H} 5), 6.79(\mathrm{~s}, 1 \mathrm{H}, \mathrm{NH}) ;{ }^{13} \mathrm{C}$ NMR $\left(\mathrm{CDCl}_{3}\right) \delta 20.9\left(4 \mathrm{CH}_{3}\right)$, $24.2\left(\mathrm{CH}_{3}, \mathrm{Me}-\mathrm{C}=\mathrm{O}\right), 43.4\left(\mathrm{CH}_{2}\right), 47.6\left(2 \mathrm{CH}, \mathrm{CHMe}_{2}\right), 62.1(2 \mathrm{CH}$, $\mathrm{C} 2$ and $\mathrm{C} 5), 65.2(2 \mathrm{CH}, \mathrm{C} 3$ and $\mathrm{C} 4), 68.6\left(2 \mathrm{CH}, \mathrm{C} 3\right.$ and $\left.\mathrm{C}^{\prime}\right)$, $70.8\left(2 \mathrm{CH}, \mathrm{C} 2\right.$ ' and $\left.\mathrm{C}^{\prime}\right), 89.1\left(\mathrm{C}, \mathrm{C} 1^{\prime}, \mathrm{C}-\mathrm{CH}_{2}\right), 94.6(\mathrm{C}, \mathrm{C} 1, \mathrm{C}-$ $\mathrm{N}), 168.3(\mathrm{C}, \mathrm{C}=\mathrm{O})$.

$\mathrm{N}$-(2-(Methoxymethyl)ferrocenyl)acetamide $\quad(\mathbf{2 d}, \quad$ racemic mixture). The general procedure 1 from 1-iodo-2 (methoxymethyl)ferrocene (1d; $0.36 \mathrm{~g}$ ) gave 2d (eluent: hexaneAcOEt $60: 40)$ in $61 \%$ yield $(0.18 \mathrm{~g})$ as an orange solid: $\mathrm{mp} 116$ $118^{\circ} \mathrm{C}$; IR (ATR) 704, 804, 999, 1032, 1090, 1189, 1273, 1305 , 1373, 1448, 1543, 1651, 2926, $3274 \mathrm{~cm}^{-1} ;{ }^{1} \mathrm{H}$ NMR $\left(\mathrm{CDCl}_{3}\right) \delta$ 2.03 (s, 3H, Me-C=O), 3.35 (s, 3H, OMe), $3.92(\mathrm{~s}, 1 \mathrm{H}, \mathrm{H} 4), 3.95$ $(\mathrm{s}, 1 \mathrm{H}, \mathrm{H} 3), 4.10(\mathrm{~s}, 5 \mathrm{H}, \mathrm{Cp}), 4.16(\mathrm{~d}, 1 \mathrm{H}, J=11.4 \mathrm{~Hz}, \mathrm{CH})$ $4.52(\mathrm{~d}, 1 \mathrm{H}, J=11.4 \mathrm{~Hz}, \mathrm{CHH}), 5.01(\mathrm{~s}, 1 \mathrm{H}, \mathrm{H} 5), 7.39$ (br s, $1 \mathrm{H}$ $\mathrm{NH}) ;{ }^{13} \mathrm{C} \mathrm{NMR}\left(\mathrm{CDCl}_{3}\right) \delta 24.2\left(\mathrm{CH}_{3}, \mathrm{Me}-\mathrm{C}=\mathrm{O}\right), 58.1\left(\mathrm{CH}_{3}, \mathrm{OMe}\right)$ $62.9(\mathrm{CH}, \mathrm{C} 5), 63.9(\mathrm{CH}, \mathrm{C} 3), 64.9(\mathrm{CH}, \mathrm{C} 4), 69.6(5 \mathrm{CH}, \mathrm{Cp})$, $69.8\left(\mathrm{CH}_{2}\right), 74.1\left(\mathrm{C}, \mathrm{C} 2, \mathrm{C}_{-} \mathrm{CH}_{2}\right), 94.4(\mathrm{C}, \mathrm{C} 1, \mathrm{C}-\mathrm{N}), 168.4(\mathrm{C}$ $\mathrm{C=O}) ; \mathrm{MS}$ (El, $70 \mathrm{eV}): 287$ [M].

$\mathrm{N}$-(3-(Methoxymethyl)ferrocenyl)acetamide $\quad(\mathbf{4 d}, \quad$ racemic mixture). The general procedure 1 from 1-iodo-3(methoxymethyl)ferrocene (3d; $0.36 \mathrm{~g}$ ) gave $4 \mathbf{d}$ (eluent: hexaneAcOEt $60: 40)$ in $51 \%$ yield $(0.15 \mathrm{~g})$ as an orange oil: IR (ATR) $731,815,1001,1082,1104,1271,1373,1448,1494,1563$, $1654,2927,3094,3271 \mathrm{~cm}^{-1} ;{ }^{1} \mathrm{H}$ NMR $\left(\mathrm{CDCl}_{3}\right) \delta 2.02(\mathrm{~s}, 3 \mathrm{H}, \mathrm{Me}$ $\mathrm{C}=0$ ), $3.29(\mathrm{~s}, 3 \mathrm{H}, \mathrm{OMe}), 4.07(\mathrm{~s}, 1 \mathrm{H}, \mathrm{H} 4), 4.12(\mathrm{~s}, 5 \mathrm{H}, \mathrm{Cp}), 4.14$ $4.18\left(\mathrm{~m}, 2 \mathrm{H}, \mathrm{CH}_{2}\right), 4.59(\mathrm{~s}, 1 \mathrm{H}, \mathrm{H} 5), 4.70(\mathrm{~s}, 1 \mathrm{H}, \mathrm{H} 2), 7.28(\mathrm{br} \mathrm{s}$, $1 \mathrm{H}, \mathrm{NH}) ;{ }^{13} \mathrm{C} \mathrm{NMR}\left(\mathrm{CDCl}_{3}\right) \delta 24.0\left(\mathrm{CH}_{3}, \mathrm{Me}-\mathrm{C}=\mathrm{O}\right), 57.7\left(\mathrm{CH}_{3}\right.$, $\mathrm{OMe}), 61.8(\mathrm{CH}, \mathrm{C} 5), 62.7(\mathrm{CH}, \mathrm{C} 2), 65.8(\mathrm{CH}, \mathrm{C} 4), 69.8(5 \mathrm{CH}$, $\mathrm{Cp}), 70.9\left(\mathrm{CH}_{2}\right), 79.7\left(\mathrm{C}, \mathrm{C} 3, \mathrm{C}-\mathrm{CH}_{2}\right), 95.3(\mathrm{C}, \mathrm{C} 1, \mathrm{C}-\mathrm{N}), 168.6$ (C, C=O); MS (El, $70 \mathrm{eV}): 287$ [M], 192. 
$N-\left(1^{\prime}-M e t h o x y m e t h y l f e r r o c e n y l\right) a c e t a m i d e \quad(6 \boldsymbol{d})$. The general procedure 1 from 1-iodo-1'-(methoxymethyl)ferrocene (5d; 0.36 g) gave 6d (eluent: heptane-AcOEt 60:40; $\mathrm{Rf}=0.80$ ) in $67 \%$ yield $(0.19 \mathrm{~g})$ as an orange solid: $\mathrm{mp} 66-68^{\circ} \mathrm{C}$; IR (ATR) 750, 772, 792, 810, 948, 1039, 1084, 1192, 1239, 1279, 1368, 1386, 1484, $1569,1653,2827,2891,2924,3104,3265 \mathrm{~cm}^{-1} ;{ }^{1} \mathrm{H}$ NMR $\left(\left(\mathrm{CD}_{3}\right)_{2} \mathrm{SO}\right) \delta 1.91(\mathrm{~s}, 3 \mathrm{H}, \mathrm{Me}-\mathrm{C}=\mathrm{O}), 3.16(\mathrm{~s}, 3 \mathrm{H}, \mathrm{OMe}), 3.92(\mathrm{t}$, $2 \mathrm{H}, J=1.8 \mathrm{~Hz}, \mathrm{H} 3$ and $\mathrm{H} 4), 4.09\left(\mathrm{t}, 2 \mathrm{H}, J=1.6 \mathrm{~Hz}, \mathrm{H} 2^{\prime}\right.$ and $\left.\mathrm{H} 5^{\prime}\right)$, $4.12\left(\mathrm{t}, 2 \mathrm{H}, J=1.6 \mathrm{~Hz}, \mathrm{H} 3^{\prime}\right.$ and $\left.\mathrm{H}^{\prime}\right), 4.13\left(\mathrm{~s}, 2 \mathrm{H}, \mathrm{CH}_{2}\right), 4.52(\mathrm{t}$, $2 \mathrm{H}, \mathrm{J}=1.8 \mathrm{~Hz}, \mathrm{H} 2$ and $\mathrm{H} 5), 9.25(\mathrm{~s}, 1 \mathrm{H}, \mathrm{NH}) ;{ }^{13} \mathrm{C} \mathrm{NMR}$ $\left(\left(\mathrm{CD}_{3}\right)_{2} \mathrm{SO}\right) \delta 23.4\left(\mathrm{CH}_{3}, M e-\mathrm{C}=\mathrm{O}\right), 56.8\left(\mathrm{CH}_{3}, \mathrm{OMe}\right), 60.8(2 \mathrm{CH}$, $\mathrm{C} 2$ and $\mathrm{C} 5), 64.1(2 \mathrm{CH}, \mathrm{C} 3$ and $\mathrm{C} 4), 68.8\left(2 \mathrm{CH}, \mathrm{C}^{\prime}\right.$ and $\left.\mathrm{C}^{\prime}\right)$, 69.6 $\left(\mathrm{CH}_{2}\right), 70.3\left(2 \mathrm{CH}, \mathrm{C}^{\prime}\right.$ and $\left.\mathrm{C}^{\prime}\right), 83.1\left(\mathrm{C}, \mathrm{C}^{\prime}, \mathrm{C}^{\prime} \mathrm{CH}_{2}\right), 96.1$ (C, C1, C-N), $167.8(\mathrm{C}, \mathrm{C}=\mathrm{O})$; MS (El, $70 \mathrm{eV}): 287$ [M], 209, 179.

$\mathrm{N}$-(3-(Hydroxymethyl)ferrocenyl)acetamide $\quad(\mathbf{4 e}, \quad$ racemic mixture). The general procedure 1 from 3 iodoferrocenemethanol (3e; $0.34 \mathrm{~g})$ gave $4 \mathrm{e}$ (eluent: AcOEt; Rf $=0.36)$ in $25.5 \%$ yield $(70 \mathrm{mg})$ as a light yellow solid: $\mathrm{mp} 182-$ $184^{\circ} \mathrm{C}$; IR (ATR) 709, 803, 823, 944, 971, 989, 1024, 1039, 1102 $1141,1174,1281,1301,1345,1380,1446,1492,1576,1639$, 2864, 2950, $3081 \mathrm{~cm}^{-1} ;{ }^{1} \mathrm{H}$ NMR $\left(\left(\mathrm{CD}_{3}\right)_{2} \mathrm{SO}\right) \delta 1.88(\mathrm{~s}, 3 \mathrm{H}, \mathrm{Me}-$ $\mathrm{C}=\mathrm{O}), 3.94(\mathrm{t}, 1 \mathrm{H}, J=1.8 \mathrm{~Hz}, \mathrm{H} 4), 4.05(\mathrm{~s}, 5 \mathrm{H}, \mathrm{Cp}), 4.12(\mathrm{dd}, 1 \mathrm{H}$, $J=12.1$ and $5.8 \mathrm{~Hz}, \mathrm{CHH}), 4.14(\mathrm{dd}, 1 \mathrm{H}, J=12.1$ and $5.8 \mathrm{~Hz}$, $\mathrm{CHH}), 4.44(\mathrm{t}, 1 \mathrm{H}, J=1.8 \mathrm{~Hz}, \mathrm{H} 5), 4.62(\mathrm{~s}, 1 \mathrm{H}, \mathrm{H} 2), 4.72(\mathrm{t}, 1 \mathrm{H}$, $J=5.8 \mathrm{~Hz}, \mathrm{OH}), 9.21(\mathrm{br} \mathrm{s}, 1 \mathrm{H}, \mathrm{NH}) ;{ }^{13} \mathrm{C} \mathrm{NMR}\left(\left(\mathrm{CD}_{3}\right)_{2} \mathrm{SO}\right) \delta 23.4$ $\left(\mathrm{CH}_{3}, \mathrm{Me}\right), 59.3\left(\mathrm{CH}_{2}\right), 60.2(\mathrm{CH}, \mathrm{C} 5), 61.5(\mathrm{CH}, \mathrm{C} 2), 63.9(\mathrm{CH}$, C4), $69.2(5 \mathrm{CH}, \mathrm{Cp}), 84.2\left(\mathrm{C}, \mathrm{C} 3, \mathrm{C}-\mathrm{CH}_{2} \mathrm{OH}\right), 95.2$ (C, C1, C$\mathrm{NHCOMe}), 167.9(\mathrm{C}, \mathrm{C}=\mathrm{O})$

$\mathrm{N}$-(1'-Hydroxymethylferrocenyl)acetamide (6e). The general procedure 1 from 1 '-iodoferrocenemethanol $(5 e ; 0.34 \mathrm{~g})$ gave $6 \mathrm{e}$ (eluent: petroleum ether-AcOEt $50: 50)$ in $18 \%$ yield $(49 \mathrm{mg})$ as an orange solid: $\mathrm{mp} 152-154^{\circ} \mathrm{C}$; IR (ATR) $715,739,761,816$, 832, 849, 922, 964, 990, 1012, 1028, 1039, 1176, 1235, 1261, $1289,1339,1353,1390,1454,1477,1570,1648,1732,2147$ 2187, 2851, 2921, 2951, 3086, $3256 \mathrm{~cm}^{-1} ;{ }^{1} \mathrm{H}$ NMR $\left(\left(\mathrm{CD}_{3}\right)_{2} \mathrm{SO}\right)$ $\delta 1.90(\mathrm{~s}, 3 \mathrm{H}, \mathrm{Me}), 3.91(\mathrm{t}, 2 \mathrm{H}, J=1.8 \mathrm{~Hz}, \mathrm{H} 3$ and $\mathrm{H} 4), 4.04(\mathrm{t}$, $2 \mathrm{H}, J=1.7 \mathrm{~Hz}, \mathrm{H} 2^{\prime}$ and 'H5'), $4.08\left(\mathrm{t}, 2 \mathrm{H}, J=1.7 \mathrm{~Hz}, \mathrm{H} 3^{\prime}\right.$ and $\left.\mathrm{H} 4^{\prime}\right), 4.18\left(\mathrm{t}, 2 \mathrm{H}, J=5.8 \mathrm{~Hz}, \mathrm{CH}_{2}\right), 4.50(\mathrm{t}, 2 \mathrm{H}, J=1.8 \mathrm{~Hz}, \mathrm{H} 2$ and $\mathrm{H} 5), 4.62(\mathrm{t}, 1 \mathrm{H}, J=5.8 \mathrm{~Hz}, \mathrm{OH}), 9.23(\mathrm{~s}, 1 \mathrm{H}, \mathrm{NH}) ;{ }^{13} \mathrm{C} \mathrm{NMR}$ $\left(\left(\mathrm{CD}_{3}\right)_{2} \mathrm{SO}\right) \delta 23.4\left(\mathrm{CH}_{3}\right), 58.7\left(\mathrm{CH}_{2}\right), 60.7(2 \mathrm{CH}, \mathrm{C} 2$ and $\mathrm{C} 5)$, $64.0(2 \mathrm{CH}, \mathrm{C} 3$ and $\mathrm{C} 4), 68.2\left(2 \mathrm{CH}, \mathrm{C} 2\right.$ ' and $\left.\mathrm{C}^{\prime}\right), 69.1\left(2 \mathrm{CH}, \mathrm{C} 3^{\prime}\right.$ and $\mathrm{C}^{\prime}$ ), $88.4\left(\mathrm{C}, \mathrm{C}^{\prime}, \mathrm{C}^{-} \mathrm{CH}_{2}\right), 95.8(\mathrm{C}, \mathrm{C} 1, \mathrm{C}-\mathrm{N}), 167.8$ (C, $\mathrm{C}=\mathrm{O})$.

$\mathrm{N}$-(2-Formylferrocenyl)acetamide (2f, racemic mixture). The general procedure 1 from 2-iodoferrocenecarboxaldehyde (1f: $0.34 \mathrm{~g})$ gave $2 f$ (eluent: petroleum ether-AcOEt 90:10 to 70:30) in $12 \%$ yield $(33 \mathrm{mg})$ as a red solid: $\mathrm{mp} 110-112{ }^{\circ} \mathrm{C}$; IR (ATR) $735,797,816,1001,1034,1106,1233,1275,1384,1435,1469$, $1530,1652,2925,3341 \mathrm{~cm}^{-1} ;{ }^{1} \mathrm{H}$ NMR $\left(\mathrm{CDCl}_{3}\right) \delta 2.12(\mathrm{~s}, 3 \mathrm{H}, \mathrm{Me})$ 4.24 (s, 5H, Cp), 4.40-4.42 (m, $2 \mathrm{H}, \mathrm{H} 3$ and $\mathrm{H} 4), 5.80(\mathrm{~s}, 1 \mathrm{H}, \mathrm{H} 5)$, 8.67 (br s, $1 \mathrm{H}, \mathrm{NH}), 10.06(\mathrm{~s}, 1 \mathrm{H}, \mathrm{CHO}) ;{ }^{13} \mathrm{C} \mathrm{NMR}\left(\mathrm{CDCl}_{3}\right) \delta 24.5$ $\left(\mathrm{CH}_{3}, \mathrm{Me}\right), 66.5(\mathrm{CH}, \mathrm{C} 5), 67.0(\mathrm{C}, \mathrm{C} 2, \mathrm{C}-\mathrm{CHO}), 67.2$ (C3 or $\left.\mathrm{C} 4\right)$, 69.6 (C3 or C4), 70.8 (5CH, Cp), $98.2(\mathrm{C}, \mathrm{C} 1, \mathrm{C}-\mathrm{N}), 169.1$ (C, $\mathrm{Me}-\mathrm{C}=\mathrm{O}), 197.2(\mathrm{CH}, \mathrm{CHO}) ; \mathrm{MS}(\mathrm{El}, 70 \mathrm{eV}): 271$ [M], 229 [M$\left.\mathrm{CH}_{3} \mathrm{CO}+\mathrm{H}\right], 207$. These analyses were found similar to those reported previously. ${ }^{[48]}$

$\mathrm{N}$-(3-Formylferrocenyl)acetamide (4f, racemic mixture). The general procedure 1 from 3-iodoferrocenecarboxaldehyde (3f; $0.34 \mathrm{~g}$ ) gave $\mathbf{4 f}$ (eluent: petroleum ether-AcOEt 40:60; $\mathrm{Rf}=0.17$ ) in $12 \%$ yield (33 mg) as an orange oil: IR (ATR) 746, 786, 823, $949,969,1003,1038,1106,1139,1242,1289,1329,1374$, $1398,1439,1489,1555,1651,1736,2854,2925,3086,3278$ $\mathrm{cm}^{-1} ;{ }^{1} \mathrm{H}$ NMR $\left(\mathrm{CDCl}_{3}\right) \delta 2.10(\mathrm{~s}, 3 \mathrm{H}, \mathrm{Me}), 4.26(\mathrm{~s}, 5 \mathrm{H}, \mathrm{Cp}), 4.66$ (dd, $1 \mathrm{H}, J=2.2$ and $1.1 \mathrm{~Hz}, \mathrm{H} 5$ ), 5.13 (dd, $1 \mathrm{H}, J=2.2$ and 1.1 $\mathrm{Hz}, \mathrm{H} 4), 5.18$ (s, 1H, H2), 7.47 (br s, 1H, NH), 9.88 (s, 1H, CHO); ${ }^{13} \mathrm{C}$ NMR $\left(\mathrm{CDCl}_{3}\right) \delta 24.2\left(\mathrm{CH}_{3}, \mathrm{Me}\right), 61.2(\mathrm{CH}, \mathrm{C} 2), 66.5(\mathrm{C} 4)$, 66.8 (C5), $71.0(5 \mathrm{CH}, \mathrm{Cp}), 75.4$ (C, C3, C-CHO), 99.3 (C, C1, C$\mathrm{N}), 168.7(\mathrm{C}, \mathrm{Me}-\mathrm{C}=\mathrm{O}), 193.8(\mathrm{CH}, \mathrm{CHO})$.

$N$-(1'-Formylferrocenyl)acetamide (6f). The general procedure 1 from 1'-iodoferrocenecarboxaldehyde $(5 \mathrm{f} ; 0.34 \mathrm{~g})$ gave $6 \mathrm{6f}$ (eluent: hexane-AcOEt $50: 50)$ in $30 \%$ yield $(80 \mathrm{mg})$ as a dark orange solid: $\mathrm{mp} 150-152^{\circ} \mathrm{C}$; IR (ATR) $734,817,1023,1039$, $1246,1288,1376,1456,1486,1574,1653,2782,2853,2926$,
$3091,3211,3260 \mathrm{~cm}^{-1} ;{ }^{1} \mathrm{H}$ NMR $\left(\mathrm{CDCl}_{3}\right) \delta 2.09$ (s, 3H, Me), 4.05 (t, $2 \mathrm{H}, J=1.8 \mathrm{~Hz}, \mathrm{H} 3$ and $\mathrm{H} 4), 4.61(\mathrm{t}, 2 \mathrm{H}, J=1.8 \mathrm{~Hz}, \mathrm{H} 3$ ' and $\mathrm{H} 4$ ') 4.71 (t, $2 \mathrm{H}, J=1.8 \mathrm{~Hz}, \mathrm{H} 2$ and $\mathrm{H} 5$ ), 4.81 (t, $2 \mathrm{H}, J=1.8 \mathrm{~Hz}$, $\mathrm{H} 2$ ' and $\mathrm{H} 5$ '), 6.70 (br s, 1H, NH), 9.79 (s, 1H, CHO); ${ }^{13} \mathrm{C} \mathrm{NMR}$ $\left(\mathrm{CDCl}_{3}\right) \delta 24.1\left(\mathrm{CH}_{3}\right), 62.5(2 \mathrm{CH}, \mathrm{C} 2$ and $\mathrm{C} 5), 66.2(2 \mathrm{CH}, \mathrm{C} 3$ and C4), $70.9\left(2 \mathrm{CH}, \mathrm{C} 2\right.$ ' and $\left.\mathrm{C}^{\prime}\right), 74.2\left(2 \mathrm{CH}, \mathrm{C}^{\prime}\right.$ ' and $\left.\mathrm{C}^{\prime}\right), 80.5(\mathrm{C}$, C1', C-CHO), 96.4 (C, C1, C-N), 168.7 (C, Me-C=O), 193.3 (CHO); MS (El, $70 \mathrm{eV}): 271$ [M], 178 [M-CpCHO]. Crystal data for 6f. $\mathrm{C}_{13} \mathrm{H}_{13} \mathrm{FeNO}_{2}, M=271.09, T=150(2) \mathrm{K}$, monoclinic $P 2_{1} / c, a=7.1408(12), b=16.661(3), c=9.5968(17) \AA, \beta=$ $102.302(6)^{\circ}, V=1115.5(3) \AA^{3}, Z=4, d=1.614 \mathrm{~g} \mathrm{~cm}^{-3}, \mu=1.338$ $\mathrm{mm}^{-1}$. A final refinement on $F^{2}$ with 2568 unique intensities and 157 parameters converged at $\omega R\left(F^{2}\right)=0.0670(R(F)=0.0292)$ for 2199 observed reflections with $I>2 \sigma(I)$. CCDC 2026535

$\mathrm{N}$-(2-Benzoylferrocenyl)acetamide (2g, racemic mixture). The general procedure 1 from (2-iodoferrocenyl)phenylketone $(\mathbf{1 g}$ $0.42 \mathrm{~g}$ ) gave $\mathbf{2 g}$ (eluent: hexane-AcOEt $60: 40$ ) in $13 \%$ yield (45 $\mathrm{mg}$ ) as a red solid: $\mathrm{mp} 82-84^{\circ} \mathrm{C}$; IR (ATR) 699, 730, 812, 901, $1004,1049,1230,1286,1344,1420,1524,1616,1685,3335$ $\mathrm{cm}^{-1} \cdot{ }^{1} \mathrm{H}$ NMR $\left(\mathrm{CDCl}_{3}\right) \delta 2.17$ (s, 3H, Me) 4.17 (s, $\left.5 \mathrm{H}, \mathrm{Cp}\right), 4.41-$ $4.44(\mathrm{~m}, 2 \mathrm{H}, \mathrm{H} 3$ and $\mathrm{H} 4), 5.89(\mathrm{~s}, 1 \mathrm{H}, \mathrm{H} 5), 7.49(\mathrm{t}, 2 \mathrm{H}, J=7.4$ $\mathrm{Hz}, \mathrm{H}^{\prime}$ ' and ' $\left.\mathrm{H}^{\prime}\right), 7.59\left(\mathrm{t}, 1 \mathrm{H}, J=7.4 \mathrm{~Hz}, \mathrm{H} 4^{\prime}\right), 7.89(\mathrm{~d}, 2 \mathrm{H}, J=$ $7.4 \mathrm{~Hz}, \mathrm{H} 2$ ' and 'H6'), 9.49 (br s, $1 \mathrm{H}, \mathrm{NH}) ;{ }^{13} \mathrm{C} \mathrm{NMR}\left(\mathrm{CDCl}_{3}\right) \delta$ $24.8\left(\mathrm{CH}_{3}, \mathrm{Me}\right), 65.2(\mathrm{C}, \mathrm{C} 2, \mathrm{C}-\mathrm{C}(=\mathrm{O}) \mathrm{Ph}), 66.3(\mathrm{CH}, \mathrm{C} 5), 68.3$ and $68.9(2 \mathrm{CH}, \mathrm{C} 3$ and $\mathrm{C} 4), 71.4(5 \mathrm{CH}, \mathrm{Cp}), 99.7(\mathrm{C}, \mathrm{C} 1, \mathrm{C}-\mathrm{N})$, $128.1\left(2 \mathrm{CH}, \mathrm{C} 2\right.$ ' and $\left.\mathrm{C}^{\prime}\right), 128.5\left(2 \mathrm{CH}, \mathrm{C}^{\prime}\right.$ ' and $\left.\mathrm{C}^{\prime}\right), 132.0(\mathrm{CH}$ C4'), 139.8 (C, C1', C-C(=O)Fc), 169.2 (C, Me- $C=O), 204.4$ (C, $\mathrm{Ph}-\mathrm{C}=\mathrm{O}) ; \mathrm{MS}(\mathrm{El}, 70 \mathrm{eV}): 347$ [M], $305\left[\mathrm{M}-\mathrm{CH}_{3} \mathrm{CO}+\mathrm{H}\right], 281$.

$\mathrm{N}$-(3-Benzoylferrocenyl)acetamide (4g, racemic mixture). The general procedure 1 from (3-iodoferrocenyl)phenylketone $\mathbf{3 g}$ $0.42 \mathrm{~g})$ gave $\mathbf{4 g}$ (eluent: petroleum ether-AcOEt 50:50; $\mathrm{Rf}=$ 0.13 ) in $19 \%$ yield $\left(66 \mathrm{mg}\right.$ ) as a red solid: $\mathrm{mp} 30-33^{\circ} \mathrm{C}$; IR (ATR) $670,697,725,823,859,910,972,1002,1106,1125,1174,1229$ $1298,1333,1375,1425,1446,1490,1560$ (s), 1616, 1661, 3085 $3279 \mathrm{~cm}^{-1} ;{ }^{1} \mathrm{H}$ NMR $\left(\mathrm{CDCl}_{3}\right) \delta 2.09$ (s, 3H, Me), 4.18 (s, 5H, Cp), 4.76 (dd, $1 \mathrm{H}, J=2.5$ and $1.3 \mathrm{~Hz}, \mathrm{H} 4), 5.15$ (dd, $1 \mathrm{H}, J=2.5$ and $1.3 \mathrm{~Hz}, \mathrm{H} 5), 5.30(\mathrm{t}, 1 \mathrm{H}, J=1.3 \mathrm{~Hz}, \mathrm{H} 2), 7.44(\mathrm{t}, 2 \mathrm{H}, J=7.1 \mathrm{~Hz}$, $\mathrm{H}^{\prime}$ and $\left.\mathrm{H5}^{\prime}\right), 7.54\left(\mathrm{t}, 1 \mathrm{H}, J=7.1 \mathrm{~Hz}, \mathrm{H} 4^{\prime}\right), 7.80(\mathrm{br} \mathrm{s}, 1 \mathrm{H}, \mathrm{NH})$, $7.86\left(\mathrm{~d}, 2 \mathrm{H}, J=7.1 \mathrm{~Hz}, \mathrm{H} 2{ }^{\prime}\right.$ and $\left.\mathrm{H} 6{ }^{\prime}\right) ;{ }^{13} \mathrm{C}$ NMR $\left(\mathrm{CDCl}_{3}\right) \delta 24.1$ $\left(\mathrm{CH}_{3}, \mathrm{Me}\right), 63.3(\mathrm{CH}, \mathrm{C} 2), 66.2(\mathrm{CH}, \mathrm{C5}), 68.6(\mathrm{CH}, \mathrm{C} 4), 71.6$ (5CH, Cp), 74.0 (C, C3, C-COPh), 98.8 (C, C1, C-NHCOMe), $128.1\left(2 \mathrm{CH}, \mathrm{C} 2\right.$ ' and $\left.\mathrm{C}^{\prime}\right), 128.4\left(2 \mathrm{CH}, \mathrm{C}^{\prime}\right.$ and $\left.\mathrm{C}^{\prime}\right), 131.8(\mathrm{CH}$ C4'), 139.6 (C, C1'), 168.9 (Me-C=O), 199.9 (C, Ph-C=O); MS $(\mathrm{El}, 70 \mathrm{eV}): 347$ [M], 282

$\mathrm{N}$-(1'-Benzoylferrocenyl)acetamide (6g). The general procedure 1 from (1'-iodoferrocenyl)phenylketone $(\mathbf{5 g} ; 0.42 \mathrm{~g})$ gave $6 \mathrm{c}$ (eluent: hexane-AcOEt $60: 40)$ in $25 \%$ yield $(85 \mathrm{mg})$ as a red solid: $\mathrm{mp} 98-100{ }^{\circ} \mathrm{C}$; IR (ATR) 704, 726, 807, 1034, 1055, 1278 , 1374, 1440, 1449, 1487, 1570, 1638, 1661, 2851, 2920, 3096, $3216,3274 \mathrm{~cm}^{-1} ;{ }^{1} \mathrm{H}$ NMR $\left(\mathrm{CDCl}_{3}\right) \delta 2.00(\mathrm{~s}, 3 \mathrm{H}, \mathrm{Me}), 4.00(\mathrm{~s}$ $2 \mathrm{H}, \mathrm{H} 3$ and $\mathrm{H} 4), 4.54(\mathrm{~s}, 2 \mathrm{H}, \mathrm{H} 2$ and $\mathrm{H} 5), 4.59(\mathrm{~s}, 2 \mathrm{H}, \mathrm{H} 3$ ' and $\left.\mathrm{H} 4^{\prime}\right), 4.87$ (s, 2H, H2' and H5'), 7.22 (br s, $\left.1 \mathrm{H}, \mathrm{NH}\right), 7.46(\mathrm{t}, 2 \mathrm{H}$, $J=7.5 \mathrm{~Hz}, \mathrm{H} 3^{\prime \prime}$ and $\left.\mathrm{H} 5^{\prime \prime}\right), 7.56\left(\mathrm{t}, 1 \mathrm{H}, J=7.5 \mathrm{~Hz}, \mathrm{H} 4{ }^{\prime \prime}\right), 7.86(\mathrm{~d}$, $2 \mathrm{H}, J=7.5 \mathrm{~Hz}, \mathrm{H} 2 "$ and $\mathrm{H} 6 ") ;{ }^{13} \mathrm{C} \mathrm{NMR}\left(\mathrm{CDCl}_{3}\right) \delta 23.8\left(\mathrm{CH}_{3}\right)$, $64.8(2 \mathrm{CH}, \mathrm{C} 2$ and $\mathrm{C} 5), 66.9(2 \mathrm{CH}, \mathrm{C} 3$ and $\mathrm{C} 4), 72.9(2 \mathrm{CH}, \mathrm{C} 2$ and $\left.\mathrm{C}^{\prime}\right), 73.7\left(2 \mathrm{CH}, \mathrm{C} 3^{\prime}\right.$ and $\left.\mathrm{C}^{\prime}\right), 79.3\left(\mathrm{C}, \mathrm{C} 1^{\prime}, \mathrm{C}-\mathrm{C}(=\mathrm{O}) \mathrm{Ph}\right)$ 94.7 (C, C1, C-N), 128.4 and 128.6 ( 2 × 2CH, C2" and C6", and C3" and C5"), 132.1 (CH, C4"), 139.4 (C, C-C(=O)FC), 169.3 (C, $\mathrm{Me}-\mathrm{C}=\mathrm{O}), 199.3(\mathrm{Ph}-\mathrm{C}=\mathrm{O})$; MS (El, $70 \mathrm{eV}): 347$ [M], 305 [M$\left.\mathrm{CH}_{3} \mathrm{CO}+\mathrm{H}\right], 178$

$\mathrm{N}$-(2-Cyanoferrocenyl)acetamide (2h, racemic mixture). The general procedure 1 from 2-iodoferrocenecarbonitrile $(1 \mathrm{~h} ; 0.34$ g) gave $2 \mathrm{~h}$ (eluent: hexane-AcOEt $60: 40$ ) in $24 \%$ yield $(64 \mathrm{mg}$ ) as an orange solid: $\mathrm{mp} 168-170^{\circ} \mathrm{C}$; IR (ATR) $817,1001,1033$, $1106,1244,1282,1368,1472,1549,1686,2223,3320 \mathrm{~cm}^{-1} ;{ }^{1} \mathrm{H}$ NMR $\left(\mathrm{CDCl}_{3}\right) \delta 2.11$ (br s, 3H, Me), 4.28 (br s, 7H, Cp, H5, H3 or $\mathrm{H} 4), 5.25$ (br s, $1 \mathrm{H}, \mathrm{H} 3$ or $\mathrm{H} 4), 7.26$ (br s, $1 \mathrm{H}, \mathrm{NH}) ;{ }^{13} \mathrm{C}$ NMR $\left(\mathrm{CDCl}_{3}\right) \delta 24.0\left(\mathrm{CH}_{3}, \mathrm{Me}\right), 44.4(\mathrm{C}, \mathrm{C} 2, \mathrm{C}-\mathrm{CN}), 65.0,66.8$ and 67.9 (C3, C4 and C5), 71.8 (5CH, Cp), 97.3 (C, C1, C-N), 119.3 $(\mathrm{C} \equiv \mathrm{N}), 169.1(\mathrm{C}, \mathrm{C}=\mathrm{O})$; MS (El, $70 \mathrm{eV}): 268[\mathrm{M}], 226[\mathrm{M}-$ $\left.\mathrm{CH}_{3} \mathrm{CO}+\mathrm{H}\right]$.

$\mathrm{N}$-(3-Cyanoferrocenyl)acetamide (4h, racemic mixture). The general procedure 1 from 3 -iodoferrocenecarbonitrile $(3 \mathbf{h} ; 0.34$ 
g) gave 4h (eluent: heptane-AcOEt $60: 40$ ) in $30 \%$ yield $(80 \mathrm{mg}$ ) as an orange oil: $\mathrm{Rf}$ (petroleum ether-AcOEt 50:50) $=0.20$; IR (ATR) 822, 1003, 1036, 1107, 1259, 1374, 1422, 1489, 1554, $1661,2224,2928,3094,3278 \mathrm{~cm}^{-1} ;{ }^{1} \mathrm{H}$ NMR $\left(\mathrm{CDCl}_{3}\right) \delta 2.08(\mathrm{~s}$, $3 \mathrm{H}, \mathrm{Me}$ ), 4.33 (s, 5H, Cp), 4.52 (br s, $1 \mathrm{H}, \mathrm{H} 5), 4.83$ (br s, 1H, H4), 5.10 (br s, 1H, H2), 7.11 (br s, $1 \mathrm{H}, \mathrm{NH}) ;{ }^{13} \mathrm{C} \mathrm{NMR}\left(\mathrm{CDCl}_{3}\right) \delta 24.1$ $\left(\mathrm{CH}_{3}, \mathrm{Me}\right), 48.2(\mathrm{C}, \mathrm{C} 3, \mathrm{C}-\mathrm{CN}), 63.7(\mathrm{CH}, \mathrm{C} 2), 63.8(\mathrm{CH}, \mathrm{C} 4)$, $68.5(\mathrm{CH}, \mathrm{C} 5), 71.9(5 \mathrm{CH}, \mathrm{Cp}), 96.7(\mathrm{C}, \mathrm{C} 1, \mathrm{C}-\mathrm{N}), 120.3(\mathrm{C} \equiv \mathrm{N})$, $168.6(\mathrm{C}, \mathrm{C}=\mathrm{O}) ; \mathrm{MS}(\mathrm{El}, 70 \mathrm{eV}): 268$ [M], $226\left[\mathrm{M}-\mathrm{CH}_{3} \mathrm{CO}+\mathrm{H}\right]$

$N-(1$ '-Cyanoferrocenyl)acetamide (6h). The general procedure 1 from 1'-iodoferrocenecarbonitrile $(\mathbf{5 h} ; 0.34 \mathrm{~g})$ gave $\mathbf{6 h}$ (eluent: heptane-AcOEt $60: 40)$ in $40 \%$ yield $(0.11 \mathrm{~g})$ as an orange solid:

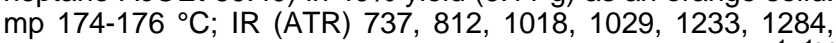
$1376,1488,1570,1660,2220,2923,3089,3212,3264 \mathrm{~cm}^{-1} ;{ }^{1} \mathrm{H}$ $\operatorname{NMR}\left(\mathrm{CDCl}_{3}\right) \delta 2.17(\mathrm{~s}, 3 \mathrm{H}, \mathrm{Me}), 4.11(\mathrm{t}, 2 \mathrm{H}, J=1.8 \mathrm{~Hz}, \mathrm{H} 3$ and $\mathrm{H} 4), 4.39\left(\mathrm{t}, 2 \mathrm{H}, J=1.8 \mathrm{~Hz}, \mathrm{H} 3^{\prime}\right.$ and $\left.\mathrm{H}^{\prime}\right), 4.69(\mathrm{t}, 2 \mathrm{H}, J=1.8 \mathrm{~Hz}$, $\mathrm{H} 2^{\prime}$ and $\left.\mathrm{H}^{\prime}\right), 4.76(\mathrm{t}, 2 \mathrm{H}, J=1.8 \mathrm{~Hz}, \mathrm{H} 2$ and $\mathrm{H} 5), 6.84(\mathrm{br} \mathrm{s}, 1 \mathrm{H}$, $\mathrm{NH}) ;{ }^{13} \mathrm{C}$ NMR $\left(\mathrm{CDCl}_{3}\right) \delta 24.2\left(\mathrm{CH}_{3}\right), 53.7\left(\mathrm{C}, \mathrm{C} 1{ }^{\prime}, \mathrm{C}-\mathrm{CN}\right), 62.9$ $(2 \mathrm{CH}, \mathrm{C} 2$ and $\mathrm{C} 5), 66.9(2 \mathrm{CH}, \mathrm{C} 3$ and $\mathrm{C} 4), 71.6\left(2 \mathrm{CH}, \mathrm{C}^{\prime}\right.$ and C4'), $72.9\left(2 \mathrm{CH}, \mathrm{C}^{\prime}\right.$ and $\left.\mathrm{C}^{\prime}\right), 96.5(\mathrm{C}, \mathrm{C} 1, \mathrm{C}-\mathrm{N}), 119.7(\mathrm{C}, \mathrm{C} \equiv \mathrm{N})$, $169.1(\mathrm{C}, \mathrm{C}=\mathrm{O})$; MS (El, $70 \mathrm{eV}): 268[\mathrm{M}], 226\left[\mathrm{M}-\mathrm{CH}_{3} \mathrm{CO}+\mathrm{H}\right]$, 178.

$\mathrm{N}$-(2-(Methoxycarbonyl)ferrocenyl)acetamide $\quad(2 \boldsymbol{i}, \quad$ racemic mixture). The general procedure 1 from methyl 2iodoferrocenecarboxylate (1i; $0.37 \mathrm{~g}$ ) gave 2i (eluent: hexaneAcOEt $60: 40)$ in $51 \%$ yield $(0.15 \mathrm{~g})$ as an orange solid: $\mathrm{mp} 106$ $108^{\circ} \mathrm{C}$; IR (ATR) 688, 811, 1035, 1099, 1190, 1232, 1302, 1454, 1536, $1682,3348 \mathrm{~cm}^{-1} ;{ }^{1} \mathrm{H}$ NMR $\left(\mathrm{CDCl}_{3}\right) \delta 2.11(\mathrm{~s}, 3 \mathrm{H}, \mathrm{Me}-\mathrm{C}=\mathrm{O})$, $3.85\left(\mathrm{~s}, 3 \mathrm{H}, \mathrm{CO}_{2} \mathrm{Me}\right), 4.15(\mathrm{~s}, 5 \mathrm{H}, \mathrm{Cp}), 4.24(\mathrm{~s}, 1 \mathrm{H}, \mathrm{H} 4), 4.51(\mathrm{~s}$, $1 \mathrm{H}, \mathrm{H} 5), 5.59(\mathrm{~s}, 1 \mathrm{H}, \mathrm{H} 3), 8.64(\mathrm{br} \mathrm{s}, 1 \mathrm{H}, \mathrm{NH}) ;{ }^{13} \mathrm{C} \mathrm{NMR}\left(\mathrm{CDCl}_{3}\right)$ $\delta 24.6\left(\mathrm{CH}_{3}, \mathrm{Me}-\mathrm{C}=\mathrm{O}\right), 51.8\left(\mathrm{CO}_{2} \mathrm{Me}\right), 58.6(\mathrm{C}, \mathrm{C} 2, \mathrm{C}-\mathrm{C}=\mathrm{O}), 64.7$ $(\mathrm{CH}, \mathrm{C} 5), 65.0(\mathrm{CH}, \mathrm{C} 3), 67.3(\mathrm{CH}, \mathrm{C} 4), 70.8(5 \mathrm{CH}, \mathrm{Cp}), 98.2(\mathrm{C}$, $\mathrm{C} 1, \mathrm{C}-\mathrm{N}), 168.7$ (C, Me-C=O), $175.0\left(\mathrm{CO}_{2} \mathrm{Me}\right)$; MS (El, $\left.70 \mathrm{eV}\right)$ : $301[\mathrm{M}], 259\left[\mathrm{M}-\mathrm{CH}_{3} \mathrm{CO}+\mathrm{H}\right]$, 198. Crystal data for $2 i$. $\mathrm{C}_{14} \mathrm{H}_{15} \mathrm{FeNO}_{3}, M=301.12, T=150(2) \mathrm{K}$, triclinic, $P-1, a=$ $6.8720(7), b=9.1004(9), c=10.9007(10) \AA, \alpha=82.245(3), \beta=$ 80.996(3), $y=74.205(3)^{\circ}, V=644.82(11) \AA^{3}, Z=2, d=1.551 \mathrm{~g}$ $\mathrm{cm}^{-3}, \mu=1.172 \mathrm{~mm}^{-1}$. A final refinement on $F^{2}$ with 2941 unique intensities and 177 parameters converged at $\omega R\left(F^{2}\right)=0.0549$ $(R(F)=0.0221)$ for 2782 observed reflections with $I>2 \sigma(I)$. CCDC 2026536.

$\mathrm{N}$-(3-(Methoxycarbonyl)ferrocenyl)acetamide (4i, racemic mixture). The general procedure 1 from methyl 3iodoferrocenecarboxylate $(3 \mathbf{i} ; 0.37 \mathrm{~g})$ gave $4 \mathbf{i}$ (eluent: AcOEtpetroleum ether $\left.60: 40 ; R_{f}=0.25\right)$ in $37 \%$ yield $(0.11 \mathrm{~g})$ as an orange oil: IR (ATR) 727, 773, 821, 906, 979, 1002, 1096, 1174, 1217, 1299, 1344, 1376, 1423, 1451, 1491, 1558, 1660, 1688, $1710,2248,2951,3095,3281 \mathrm{~cm}^{-1} ;{ }^{1} \mathrm{H}$ NMR $\left(\mathrm{CDCl}_{3}\right) \delta 2.08(\mathrm{~s}$ $3 \mathrm{H}, \mathrm{Me}-\mathrm{C}=\mathrm{O}), 3.79\left(\mathrm{~s}, 3 \mathrm{H}, \mathrm{CO}_{2} \mathrm{Me}\right), 4.20(\mathrm{~s}, 5 \mathrm{H}, \mathrm{Cp}), 4.68$ (dd, $1 \mathrm{H}, J=2.6$ and $1.4 \mathrm{~Hz}, \mathrm{H} 4), 4.90(\mathrm{dd}, 1 \mathrm{H}, J=2.6$ and $1.4 \mathrm{~Hz}$, $\mathrm{H} 5), 5.14(\mathrm{t}, 1 \mathrm{H}, J=1.4 \mathrm{~Hz}, \mathrm{H} 2), 6.73(\mathrm{br} \mathrm{s}, 1 \mathrm{H}, \mathrm{NH}) ;{ }^{13} \mathrm{C} \mathrm{NMR}$ $\left(\mathrm{CDCl}_{3}\right) \delta 24.2\left(\mathrm{CH}_{3}, \mathrm{Me}-\mathrm{C}=\mathrm{O}\right), 51.7\left(\mathrm{CO}_{2} \mathrm{Me}\right), 62.3(\mathrm{CH}, \mathrm{C} 2)$, $64.7(\mathrm{CH}, \mathrm{C} 5), 67.0(\mathrm{CH}, \mathrm{C} 4), 67.2(\mathrm{C}, \mathrm{C} 3, \mathrm{C}-\mathrm{C}=\mathrm{O}), 71.0(5 \mathrm{CH}$, $\mathrm{Cp}), 97.1$ (C, C1, C-N), $168.4(\mathrm{C}, \mathrm{Me}-\mathrm{C}=\mathrm{O}), 172.4\left(\mathrm{CO}_{2} \mathrm{Me}\right)$; $\mathrm{MS}$ $(\mathrm{El}, 70 \mathrm{eV})$ : 301 [M], 206. Crystal data for 4 i. $2\left(\mathrm{C}_{14} \mathrm{H}_{15} \mathrm{FeNO}_{3}\right) \cdot \mathrm{H}_{2} \mathrm{O}, M=620.25, T=150(2) \mathrm{K}$, monoclinic, $C \mathrm{c}$, $a=18.268(4), b=7.3729(12), c=21.942(4) \AA, \beta=115.744(6)^{\circ}$, $V=2662.0(8) \AA^{3}, Z=4, d=1.548 \mathrm{~g} \mathrm{~cm}^{-3}, \mu=1.140 \mathrm{~mm}^{-1}$. A final refinement on $F^{2}$ with 6115 unique intensities and 342 parameters converged at $\omega R\left(F^{2}\right)=0.0615(R(F)=0.0253)$ for 5947 observed reflections with $I>2 \sigma(I)$. CCDC 2026537.

$N-\left(1\right.$ '-(Methoxycarbonyl)ferrocenyl)acetamide $\quad$ (6i)..$^{[49]} \quad$ The general procedure 1 from methyl 1'-iodoferrocenecarboxylate $(5 \mathbf{i} ; 0.37 \mathrm{~g})$ gave $6 \mathbf{i}$ (eluent: hexane-AcOEt $50: 50 ; \mathrm{Rf}=0.85)$ in $54 \%$ yield $(0.16 \mathrm{~g})$ as an orange solid: $\mathrm{mp} 96-96{ }^{\circ} \mathrm{C}$; IR (ATR) $773,818,968,1031,1143,1195,1280,1370,1467,1564,1657$, $1696,2953,3095,3213,3265,3450,3557 \mathrm{~cm}^{-1} ;{ }^{1} \mathrm{H}$ NMR $\left(\mathrm{CDCl}_{3}\right) \delta 2.06(\mathrm{~s}, 3 \mathrm{H}, \mathrm{Me}-\mathrm{C}=\mathrm{O}), 3.78\left(\mathrm{~s}, 3 \mathrm{H}, \mathrm{CO}_{2} \mathrm{Me}\right), 4.01$ (s, $2 \mathrm{H}, \mathrm{H} 3$ and $\mathrm{H} 4), 4.39\left(\mathrm{~s}, 2 \mathrm{H}, \mathrm{H} 3^{\prime}\right.$ and $\left.\mathrm{H}^{\prime}\right), 4.59(\mathrm{~s}, 2 \mathrm{H}, \mathrm{H} 2$ and $\mathrm{H} 5), 4.77$ (s, 2H, H2' and $\mathrm{H}^{\prime}$ ), 7.17 (br s, $\left.1 \mathrm{H}, \mathrm{NH}\right) ;{ }^{13} \mathrm{C}$ NMR $\left(\mathrm{CDCl}_{3}\right) \delta 24.0\left(\mathrm{CH}_{3}, \mathrm{Me}-\mathrm{C}=\mathrm{O}\right), 51.8\left(\mathrm{CH}_{3}, \mathrm{CO}_{2} \mathrm{Me}\right), 63.4(2 \mathrm{CH}$, $\mathrm{C} 2$ and $\mathrm{C} 5), 66.4(2 \mathrm{CH}, \mathrm{C} 3$ and $\mathrm{C} 4), 71.2\left(2 \mathrm{CH}, \mathrm{C} 2\right.$ ' and $\left.\mathrm{C}^{\prime}\right)$, 72.4 (2CH, C3' and C4'), 95.2 (C, C1, C-N), 168.9 (C, Me- $\mathrm{C}=\mathrm{O})$,
$171.9\left(\mathrm{CO}_{2} \mathrm{Me}\right), \mathrm{C1}^{\prime}$ not seen; $\mathrm{MS}$ (El, $\left.70 \mathrm{eV}\right): 301$ [M], 179 [MCpNHCOMe].

\section{$\mathrm{N}$-(2-(Diisopropylaminocarbonyl)ferrocenyl)acetamide}

$(2 j$,

racemic mixture). The general procedure 1 from $\mathrm{N}, \mathrm{N}$-diisopropyl2-iodoferrocenecarboxamide (1) $; 0.44 \mathrm{~g})$ gave $2 \mathbf{j}$ (eluent: hexane-AcOEt $60: 40$ ) in $15 \%$ yield $(53 \mathrm{mg})$ as an orange solid: mp 104-106 ${ }^{\circ} \mathrm{C}$; IR (ATR) 760, 806, 1034, 1161, 1254, 1332 , $1368,1455,1581,1684,2970 \mathrm{~cm}^{-1} ;{ }^{1} \mathrm{H}$ NMR $\left(\mathrm{CDCl}_{3}\right) \delta 1.42(\mathrm{br}$ $\mathrm{s}, 12 \mathrm{H}, \mathrm{Me}$ ), 2.10 (s, 3H, Me), 3.51 (br s, $1 \mathrm{H}, \mathrm{CHMe}$ ) 4.12-4.15 $(\mathrm{m}, 2 \mathrm{H}, \mathrm{H} 3$ and $\mathrm{H} 4), 4.17$ (s, 5H, Cp), 4.85 (br s, 1H, CHMe 5.53 (dd, $1 \mathrm{H}, J=2.3$ and $1.3 \mathrm{~Hz}, \mathrm{H} 5), 9.27$ (br s, $1 \mathrm{H}, \mathrm{NH}) ;{ }^{13} \mathrm{C}$ NMR $\left(\mathrm{CDCl}_{3}\right) \delta 21.4\left(4 \mathrm{CH}_{3}\right), 24.8\left(\mathrm{CH}_{3}\right), 47.0$ and $49.8(2 \mathrm{CH}$, $\left.\mathrm{CHMe}_{2}\right), 63.9(\mathrm{CH}, \mathrm{C} 3$ or $\mathrm{C} 4), 64.3(\mathrm{CH}, \mathrm{C} 5), 65.6(\mathrm{CH}, \mathrm{C} 3$ or C4), $66.4(\mathrm{C}, \mathrm{C} 2, \mathrm{C}-\mathrm{C}=\mathrm{O}), 70.9(5 \mathrm{CH}, \mathrm{Cp}), 98.8(\mathrm{C}, \mathrm{C} 1, \mathrm{C}-\mathrm{N})$ 168.7 (C, Me- $C=O), 172.0(\mathrm{C}, \mathrm{N}-\mathrm{C}=\mathrm{O})$; $\mathrm{MS}(\mathrm{El}, 70 \mathrm{eV}): 370$ [M], 305 [M-Cp], 269.

\section{N-(3-(Diisopropylaminocarbonyl)ferrocenyl)acetamide}

(4j,

racemic mixture). The general procedure 1 from $\mathrm{N}, \mathrm{N}$-diisopropyl3 -iodoferrocenecarboxamide $(\mathbf{3 j} ; 0.44 \mathrm{~g})$ gave $\mathbf{4 j}$ (eluent: hexane-AcOEt $50: 50)$ in $77 \%$ yield $(0.27 \mathrm{~g})$ as an orange solid: mp 168-170 ${ }^{\circ} \mathrm{C}$; IR (ATR) 760, 806, 823, 895, 943, 976, 1003, $1034,1054,1106,1161,1198,1216,1254,1272,1316,1332$, $1368,1409,1452,1497,1577,1684,2971,3098,3226 \mathrm{~cm}^{-1} ;{ }^{1} \mathrm{H}$ NMR $\left(\mathrm{CDCl}_{3}\right) \delta 1.34$ (br s, 12H, Me), 2.06 (s, 3H, Me-C=O), 3.44 (br s, $1 \mathrm{H}, \mathrm{CHMe}_{2}$ ), 4.20 (s, 5H, Cp), $4.41(\mathrm{~s}, 1 \mathrm{H}, \mathrm{H} 4), 4.69$ (br s, $1 \mathrm{H}, \mathrm{CHMe}$ ), $4.83(\mathrm{~s}, 1 \mathrm{H}, \mathrm{H} 5), 5.03(\mathrm{~s}, 1 \mathrm{H}, \mathrm{H} 2), 7.70$ (br s, $1 \mathrm{H}$, $\mathrm{NH}) ;{ }^{13} \mathrm{C} \mathrm{NMR}\left(\mathrm{CDCl}_{3}\right) \delta 21.3\left(4 \mathrm{CH}_{3}, \mathrm{CHMe}\right), 24.0\left(\mathrm{CH}_{3}, \mathrm{Me}-\right.$ $\mathrm{C}=\mathrm{O}), 46.5\left(\mathrm{CH}, \mathrm{CHMe}_{2}\right), 49.6\left(\mathrm{CH}, \mathrm{CHMe}_{2}\right), 62.7(\mathrm{CH}, \mathrm{C} 5)$, $63.3(\mathrm{CH}, \mathrm{C} 2), 66.3(\mathrm{CH}, \mathrm{C} 4), 70.9(5 \mathrm{CH}, \mathrm{Cp}), 76.4(\mathrm{C}, \mathrm{C} 3, \mathrm{C}-$ $\mathrm{C}=\mathrm{O}), 95.9(\mathrm{C}, \mathrm{C} 1, \mathrm{C}-\mathrm{N}), 169.1$ (C, N-C=O), 169.7 (C, Me-C=O) MS (El, $70 \mathrm{eV}): 370$ [M], 305 [M-Cp]. Crystal data for 4j. $\mathrm{C}_{19} \mathrm{H}_{26} \mathrm{FeN}_{2} \mathrm{O}_{2}, M=370.27, T=150(2) \mathrm{K}$, triclinic, $P-1, a=$ 9.9851(13), $b=13.3586(18), c=14.9260$ (19) $\AA, \alpha=102.450$ (5), $\beta=96.929(5), y=109.697(4) \circ, V=1789.4(4) \AA^{3}, Z=4, d=$ $1.374 \mathrm{~g} \mathrm{~cm}^{-3}, \mu=0.856 \mathrm{~mm}^{-1}$. A final refinement on $F^{2}$ with 8084 unique intensities and 449 parameters converged at $\omega R\left(F^{2}\right)=$ $0.0911(R(F)=0.0434)$ for 6640 observed reflections with $I>$ $2 \sigma(I)$. CCDC 2026538.

$N$-(1'-(Diisopropylaminocarbonyl)ferrocenyl)acetamide (6j). The general procedure 1 from 1'-iodo- $N, N$ diisopropylferrocenecarboxamide $(5 \mathbf{j} ; 0.44 \mathrm{~g})$ gave $6 \mathbf{j}$ (eluent: heptane-AcOEt $60: 40)$ in $39 \%$ yield $(0.15 \mathrm{~g})$ as an orange solid: mp 133-135 ${ }^{\circ} \mathrm{C}$; IR (ATR) 800, 1025, 1043, 1200, 1321, 1333 , 1369, 1463, 1532, 1603, 1672, 2923, 2956, $3294 \mathrm{~cm}^{-1} ;{ }^{1} \mathrm{H}$ NMR $\left(\mathrm{CDCl}_{3}\right) \delta 1.12(\mathrm{~d}, 6 \mathrm{H}, J=6.5 \mathrm{~Hz}, \mathrm{CHMe}), 1.50(\mathrm{~d}, 6 \mathrm{H}, J=6.5$ $\mathrm{Hz}, \mathrm{CHMe}_{2}$ ), 2.07 (s, 3H, Me-C=O), 3.44 (sept, $1 \mathrm{H}, J=6.5 \mathrm{~Hz}$, $\mathrm{CHMe}_{2}$ ), 4.04 (t, $2 \mathrm{H}, J=1.9 \mathrm{~Hz}, \mathrm{H} 3$ and $\mathrm{H} 4$ ), 4.19 (sept, $1 \mathrm{H}, J=$ $\left.6.5 \mathrm{~Hz}, \mathrm{CH} \mathrm{Me}_{2}\right), 4.27\left(\mathrm{t}, 2 \mathrm{H}, J=1.9 \mathrm{~Hz}, \mathrm{H} 3^{\prime}\right.$ and $\mathrm{H}^{\prime}$ ), $4.44(\mathrm{t}, 4 \mathrm{H}$ $J=1.9 \mathrm{~Hz}, \mathrm{H} 2, \mathrm{H} 5, \mathrm{H} 2{ }^{\prime}$ and $\mathrm{H}^{\prime}$ ), 9.36 (br s, $1 \mathrm{H}, \mathrm{NH}$ ); ${ }^{13} \mathrm{C}$ NMR $\left(\mathrm{CDCl}_{3}\right) \delta 21.1\left(4 \mathrm{CH}_{3}, \mathrm{CHMe}_{2}\right), 23.7\left(\mathrm{CH}_{3}, M e-\mathrm{C}=\mathrm{O}\right), 46.5(\mathrm{CH}$ $\left.\mathrm{CHMe}_{2}\right), 50.6\left(\mathrm{CH}, \mathrm{CHMe}_{2}\right), 66.7(2 \mathrm{CH}, \mathrm{C3}$ and $\mathrm{C} 4), 67.7(2 \mathrm{CH})$, 69.0 (2CH, C3' and C4'), $70.1(2 \mathrm{CH}), 83.7$ (C, C1', C-CONiPr 2 ), 92.7 (C, C1, C-N), 170.2 (C, CONiPr $\left.{ }_{2}\right), 170.5$ (C, Me-C=O); MS $(\mathrm{El}, 70 \mathrm{eV}): 313$ [M-NHAc+H], 213 [M-NHAc-NiPr$\left.{ }_{2}+\mathrm{H}\right]$. Crystal data for 6j. $\mathrm{C}_{19} \mathrm{H}_{26} \mathrm{FeN}_{2} \mathrm{O}_{2}, M=370.27, T=150(2) \mathrm{K}$, monoclinic, $P 2_{1} / c, a=10.8869(16), b=11.0850(19), c=14.529$ (3) $\AA, \beta=$ 90.342(6) ${ }^{\circ}, V=1753.3(5) \AA^{3}, Z=4, d=1.403 \mathrm{~g} \mathrm{~cm}^{-3}, \mu=0.874$ $\mathrm{mm}^{-1}$. A final refinement on $F^{2}$ with 4027 unique intensities and 225 parameters converged at $\omega R\left(F^{2}\right)=0.0788(R(F)=0.0334)$ for 3329 observed reflections with $I>2 \sigma(I)$. CCDC 2026539

$\mathrm{N}$-(3-(Dimethylamino)ferrocenyl)acetamide (4k, stereoisomeric mixture due to rotamers). The general procedure 1 from 3-iodo$\mathrm{N}, \mathrm{N}$-dimethylferroceneamine (3k; $50 \mathrm{mg}, 0.15 \mathrm{mmol})$ gave $\mathbf{4 k}$ (eluent: AcOEt-petroleum ether 60:40; Rf $=0.14$ ) in $28 \%$ yield (12 mg) as a brown solid: $\mathrm{mp} 150-154{ }^{\circ} \mathrm{C}$ (decomposition); IR (ATR) 716, 798, 810, 823, 893, 952, 974, 994, 1002, 1012, 1043, $1101,1131,1177,1272,1371,1421,1444,1514,1536,1649$, 2787, 2849, 2919, 3091, $3260 \mathrm{~cm}^{-1} ;{ }^{1} \mathrm{H}$ NMR $\left(\mathrm{CDCl}_{3},{ }^{*}\right.$ used for the minor compound) $\delta 1.89^{\star}$ and $2.03(2 \mathrm{~s}, 3 \mathrm{H}, \mathrm{Me}-\mathrm{C}=\mathrm{O}), 2.55^{\star}$ and $2.61\left(2 \mathrm{~s}, 6 \mathrm{H}, \mathrm{NMe}_{2}\right), 3.64$ and $3.71^{*}(2 \mathrm{~s}, 1 \mathrm{H}, \mathrm{H} 5), 3.92^{*}$ and $4.36(2 \mathrm{~s}, 1 \mathrm{H}, \mathrm{H} 2), 4.10^{*}$ and $4.33(2 \mathrm{~s}, 1 \mathrm{H}, \mathrm{H} 4), 4.24$ and $4.26^{\star}$ $(2 \mathrm{~s}, 5 \mathrm{H}, \mathrm{Cp}), 6.56$ and $6.73^{*}(2 \mathrm{br} \mathrm{s}, 1 \mathrm{H}, \mathrm{NH}) ;{ }^{13} \mathrm{C} \mathrm{NMR}\left(\mathrm{CDCl}_{3}\right.$, used for the minor compound) $\delta 20.3^{*}$ and $24.2\left(\mathrm{CH}_{3}, M e-\mathrm{C}=\mathrm{O}\right)$ $42.1^{*}$ and $42.3\left(2 \mathrm{CH}_{3}, \mathrm{NMe}_{2}\right), 50.5$ and $54.5^{*}(\mathrm{CH}, \mathrm{C} 2), 51.0$ and 
52.7 ${ }^{*}(\mathrm{CH}, \mathrm{C} 5), 56.9$ and $62.9^{*}(\mathrm{CH}, \mathrm{C} 4), 68.3$ and $68.6^{*}(5 \mathrm{CH}$, $\mathrm{Cp}), 89.1^{*}$ and 90.7 (C, C1, C-NHCOMe), 112.4 and $113.4^{*}$ (C, C3, $\left.C-\mathrm{NMe}_{2}\right), 168.4$ and $174.3^{*}(\mathrm{C}, \mathrm{Me}-\mathrm{C}=\mathrm{O})$.

$\mathrm{N}$-(2-(tert-Butoxycarbonylamino)ferrocenyl)acetamide

(2I, racemic mixture). The general procedure 1 from 1-(tertbutoxycarbonylamino)-2-iodoferrocene (1I; $0.32 \mathrm{~g}, 0.75 \mathrm{mmol})$ gave 2l (eluent: petroleum ether-AcOEt 50:50; $\mathrm{Rf}=0.41$ ) in 8.5\% yield $(23 \mathrm{mg})$ as a yellow solid: $\mathrm{mp} 142-144{ }^{\circ} \mathrm{C}$; IR (ATR) 776 , 806, 881, 943, 999, 1019, 1049, 1072, 1105, 1157, 1228, 1365, $1533,1690,1725,2973,3323 \mathrm{~cm}^{-1} ;{ }^{1} \mathrm{H}$ NMR $\left(\mathrm{CDCl}_{3}\right) \delta 1.51(\mathrm{~s}$, $9 \mathrm{H}, \mathrm{tBu}), 2.08(\mathrm{~s}, 3 \mathrm{H}, \mathrm{Me}-\mathrm{C}=\mathrm{O}), 3.87(\mathrm{~s}, 1 \mathrm{H}, \mathrm{H} 4), 4.19(\mathrm{~s}, 5 \mathrm{H}$, $\mathrm{Cp}), 4.33(\mathrm{~s}, 1 \mathrm{H}, \mathrm{H} 3), 4.56(\mathrm{~s}, 1 \mathrm{H}, \mathrm{H} 5), 6.52(\mathrm{br} \mathrm{s}, 1 \mathrm{H}, \mathrm{NH}), 7.94$ (br s, $1 \mathrm{H}, \mathrm{NH}) ;{ }^{13} \mathrm{C} \mathrm{NMR}\left(\mathrm{CDCl}_{3}\right) \delta 24.2\left(\mathrm{CH}_{3}, M e-\mathrm{C}=\mathrm{O}\right), 28.4$ $\left(3 \mathrm{CH}_{3}, \mathrm{Me}_{3} \mathrm{C}\right), 60.2(\mathrm{CH}, \mathrm{C} 3), 61.0(\mathrm{CH}, \mathrm{C} 5), 61.2(\mathrm{CH}, \mathrm{C} 4), 70.5$ $(5 \mathrm{CH}, \mathrm{Cp}), 80.7\left(\mathrm{C}, \mathrm{Me}_{3} \mathrm{C}\right), 86.2$ (C, C1, C-NHCOMe), 87.8 (C, $\left.\mathrm{C} 2, \mathrm{C}-\mathrm{NHCO}_{2} \mathrm{tBu}\right), 154.5\left(\mathrm{C}, \mathrm{CO}_{2} \mathrm{tBu}\right), 169.2(\mathrm{C}, \mathrm{Me}-\mathrm{C}=\mathrm{O})$

\section{$\mathrm{N}$-(3-(tert-Butoxycarbonylamino)ferrocenyl)acetamide}

$(4 I$, racemic mixture). The general procedure 1 from $\mathrm{N}$-(tertbutoxycarbonyl)-3-iodoferroceneamine (3l; $0.30 \mathrm{~g}, 0.70 \mathrm{mmol}$ ) gave 4I (eluent: AcOEt-petroleum ether 60:40; $\mathrm{Rf}=0.36$ ) in 17\% yield (43 mg) as an orange solid: $\mathrm{mp} 206-209{ }^{\circ} \mathrm{C}$ (decomposition); IR (ATR) 678, 730, 756, 813, 881, 936, 970, $999,1028,1054,1105,1155$ (s), 1252, 1356, 1366, 1459, 1498, 1567 (s), 1662, 1692, 2979, 3081, $3222 \mathrm{~cm}^{-1} ;{ }^{1} \mathrm{H}$ NMR $\left(\mathrm{CD}_{3} \mathrm{CN}\right)$ $\delta 1.46(\mathrm{~s}, 9 \mathrm{H}, \mathrm{tBu}), 1.91(\mathrm{~s}, 3 \mathrm{H}, \mathrm{Me}-\mathrm{C}=\mathrm{O}), 4.09$ (s, 5H, Cp), 4.23 (s, $1 \mathrm{H}, \mathrm{H} 4$ or H5), $4.29(\mathrm{~s}, 1 \mathrm{H}, \mathrm{H} 4$ or H5), $4.90(\mathrm{~s}, 1 \mathrm{H}, \mathrm{H} 2), 6.60$ (br s, $1 \mathrm{H}, \mathrm{NH}), 7.53$ (br s, $1 \mathrm{H}, \mathrm{NH}) ;{ }^{13} \mathrm{C}$ NMR $\left(\mathrm{CD}_{3} \mathrm{CN}\right) \delta 23.7$ $\left(\mathrm{CH}_{3}, M e-\mathrm{C}=\mathrm{O}\right), 28.5\left(3 \mathrm{CH}_{3}, \mathrm{Me}_{3} \mathrm{C}\right), 56.0(\mathrm{CH}, \mathrm{C} 2), 57.2(\mathrm{CH}$, $\mathrm{C} 4$ or $\mathrm{C} 5), 57.8(\mathrm{CH}, \mathrm{C} 4$ or $\mathrm{C} 5), 70.9(5 \mathrm{CH}, \mathrm{Cp}), 79.1\left(\mathrm{C}, \mathrm{CMe}_{3}\right)$, 92.6 (C, C1, C-NHCOMe), 94.2 (C, C3, C-NHCO ${ }_{2} \mathrm{tBu}$ ), 154.4 (C, $\mathrm{CO}_{2} \mathrm{tBu}^{\mathrm{B}}, 169.3(\mathrm{C}, \mathrm{Me}-\mathrm{C}=\mathrm{O})$

$\mathrm{N}$-(1'-(tert-Butoxycarbonylamino)ferrocenyl)acetamide (6I). The general procedure 1 from $N$-(tert-butoxycarbonyl)-1'iodoferroceneamine $(5 \mathrm{I} ; 0.30 \mathrm{~g}, 0.70 \mathrm{mmol}$ ) gave $6 \mathrm{I}$ (eluent: petroleum ether-AcOEt $50: 50)$ in $30 \%$ yield $(80 \mathrm{mg}$ ) as an orange solid: $\mathrm{mp} 82-84^{\circ} \mathrm{C}$; IR (ATR) $670,701,726,793,816,826,860$, $926,1008,1028,1055,1105,1132,1155,1180,1223,1293$, 1333, 1354, 1368, 1381, 1402, 1422, 1446, 1487, 1574, 1598, 2853, 2923, 3031, $3094 \mathrm{~cm}^{-1}$; ${ }^{1} \mathrm{H}$ NMR $\left(\left(\mathrm{CD}_{3}\right)_{2} \mathrm{SO}\right) \delta 1.44(\mathrm{~s}, 9 \mathrm{H}$, t $\mathrm{Bu}$ ), 1.90 (s, 3H, Me-C=O), 3.83 (s, 2H, H3' and $\mathrm{H}^{\prime}$ '), 3.85 (s, $2 \mathrm{H}, \mathrm{H} 3$ and $\mathrm{H} 4$ ), 4.36 (br s, $2 \mathrm{H}, \mathrm{H} 2$ ' and $\left.\mathrm{H}^{\prime}\right), 4.45(\mathrm{~s}, 2 \mathrm{H}, \mathrm{H} 2$ and $\mathrm{H} 5), 8.23\left(\mathrm{~s}, 1 \mathrm{H}, \mathrm{NHCO}_{2} \mathrm{HBu}^{\mathrm{B}}, 9.06(\mathrm{~s}, 1 \mathrm{H}, \mathrm{NHCOMe}) ;{ }^{13} \mathrm{C}\right.$ NMR $\left(\left(\mathrm{CD}_{3}\right)_{2} \mathrm{SO}\right) \delta 23.4\left(\mathrm{CH}_{3}, \mathrm{Me}-\mathrm{C}=\mathrm{O}\right), 28.2\left(3 \mathrm{CH}_{3}, \mathrm{CMe}_{3}\right)$, $61.0\left(2 \mathrm{CH}, \mathrm{C2}\right.$ ' and $\left.\mathrm{C}^{\prime}\right), 61.6(2 \mathrm{CH}, \mathrm{C} 2$ and $\mathrm{C} 5), 64.5\left(2 \mathrm{CH}, \mathrm{C} 3^{\prime}\right.$ and $\left.\mathrm{C}^{\prime}\right), 64.7(2 \mathrm{CH}, \mathrm{C} 3$ and $\mathrm{C} 4), 78.3\left(\mathrm{C}, \mathrm{CMe}_{3}\right), 95.5(\mathrm{C}, \mathrm{C} 1$, $C$-NHCOMe), 96.9 (C, C1', C-NHCO $\left.{ }_{2} t \mathrm{Bu}\right), 153.1\left(\mathrm{NHCO}_{2} t \mathrm{Bu}\right)$, $167.7(\mathrm{C}, \mathrm{Me}-\mathrm{C}=\mathrm{O})$.

$\mathrm{N}$-(2-Fluoroferrocenyl)acetamide $(2 \mathrm{~m}$, racemic mixture). The general procedure 1 from 1-fluoro-2-iodoferrocene $(1 \mathrm{~m} ; 0.33 \mathrm{~g})$ gave $2 \mathrm{~m}$ (eluent: hexane-AcOEt $60: 40)$ in $34 \%$ yield $(89 \mathrm{mg})$ as a dark orange solid: $\mathrm{mp} 172-174{ }^{\circ} \mathrm{C}$; IR (ATR) $665,807,830$, $997,1020,1104,1116,1200,1265,1367,1409,1456,1486$, $1512,1657,1679,2923,3306 \mathrm{~cm}^{-1} ;{ }^{1} \mathrm{H}$ NMR $\left(\mathrm{CDCl}_{3}\right) \delta 2.12(\mathrm{~s}$, $3 \mathrm{H}, \mathrm{Me}$ ), 3.66 (br s, $1 \mathrm{H}, \mathrm{H} 4), 4.18$ (br s, $1 \mathrm{H}, \mathrm{H} 3), 4.23$ (s, 5H, Cp), 4.65 (br s, $1 \mathrm{H}, \mathrm{H} 5), 6.99(\mathrm{br} \mathrm{s}, 1 \mathrm{H}, \mathrm{NH}) ;{ }^{13} \mathrm{C} \mathrm{NMR}\left(\mathrm{CDCl}_{3}\right) \delta 24.0$ $\left(\mathrm{CH}_{3}, \mathrm{Me}\right), 52.6(\mathrm{~d}, \mathrm{CH}, J=13.1 \mathrm{~Hz}, \mathrm{C} 3), 56.4(\mathrm{CH}, \mathrm{C} 4), 57.2$ $(\mathrm{CH}, \mathrm{C} 5), 70.6(5 \mathrm{CH}, \mathrm{Cp}), 82.7$ (d, C, $J=10.7 \mathrm{~Hz}, \mathrm{C} 1, \mathrm{C}-\mathrm{N})$, 128.3 (d, C $J=269 \mathrm{~Hz}, \mathrm{C} 2, \mathrm{C}-\mathrm{F}), 168.9$ (C, Me- $\mathrm{C}=\mathrm{O}$ ); ${ }^{19} \mathrm{~F}$ NMR $\left(\mathrm{CDCl}_{3}\right) \delta$-197.4; MS (El, $\left.70 \mathrm{eV}\right): 261[\mathrm{M}], 219\left[\mathrm{M}-\mathrm{CH}_{3} \mathrm{CO}+\mathrm{H}\right]$, 198.

$\mathrm{N}$-(3-Fluoroferrocenyl)acetamide $\mathbf{( 4 m}$, racemic mixture). The general procedure 1 from 1 -fluoro-3-iodoferrocene $(3 \mathrm{~m} ; 0.33 \mathrm{~g})$ gave $\mathbf{4 m}$ (eluent: hexane-AcOEt $60: 40)$ in $57 \%$ yield $(0.15 \mathrm{~g})$ as an orange solid: $\mathrm{mp} 100-102{ }^{\circ} \mathrm{C}$; IR (ATR) 707, 763, 808, 836, $888,921,947,964,1001,1022,1107,1125,1180,1264,1348$, $1372,1410,1453,1486,1559,1659,1780,2931,3098,3278$ $\mathrm{cm}^{-1} ;{ }^{1} \mathrm{H} \mathrm{NMR}\left(\left(\mathrm{CD}_{3}\right)_{2} \mathrm{SO}\right) \delta 1.43(\mathrm{~s}, 3 \mathrm{H}, \mathrm{Me}), 3.73(\mathrm{~s}, 1 \mathrm{H}, \mathrm{H} 5)$, 3.76 (s, 5H, Cp), $3.81(\mathrm{~s}, 1 \mathrm{H}, \mathrm{H} 4), 4.42(\mathrm{~s}, 1 \mathrm{H}, \mathrm{H} 2), 8.74$ (br s, $1 \mathrm{H}, \mathrm{NH}) ;{ }^{13} \mathrm{C}$ NMR $\left(\left(\mathrm{CD}_{3}\right)_{2} \mathrm{SO}\right) \delta 23.3\left(\mathrm{CH}_{3}, \mathrm{Me}\right), 49.9(\mathrm{~d}, \mathrm{CH}, J$ $=16.8 \mathrm{~Hz}, \mathrm{C} 2), 51.2(\mathrm{~d}, \mathrm{CH}, J=14.9 \mathrm{~Hz}, \mathrm{C} 4), 53.0(\mathrm{~d}, \mathrm{CH}, J=$ $2.3 \mathrm{~Hz}, \mathrm{C} 5), 70.2(5 \mathrm{CH}, \mathrm{Cp}), 88.8(\mathrm{~d}, \mathrm{C}, J=5.1 \mathrm{~Hz}, \mathrm{C} 1, \mathrm{C}-\mathrm{N})$, 132.9 (d, C, $J=267 \mathrm{~Hz}, \mathrm{C} 3, \mathrm{C}-\mathrm{F}), 168.1$ (C, Me-C=O); ${ }^{19} \mathrm{~F}$ NMR
$\left.\left(\mathrm{CD}_{3}\right)_{2} \mathrm{SO}\right) \delta$-191.3; MS (El, $\left.70 \mathrm{eV}\right): 261$ [M], 219 [M- $\left.\mathrm{CH}_{3} \mathrm{CO}+\mathrm{H}\right]$, 196.

$N$-(2-(N-Methyl-3-indolylmethyl)ferrocenyl)-2-pyrrolidinone (4n, racemic mixture). The general procedure 1 but from 1 -iodo-2- $(N$ methyl-3-indolylmethyl)ferrocene $(0.30 \mathrm{~g} ; 0.66 \mathrm{mmol})$ gave $\mathbf{4 n}$ (eluent: petroleum ether-AcOEt 50:50; $\mathrm{Rf}=0.22$ ) in $11 \%$ yield (30 mg) as an orange sticky oil: IR (ATR) 737, 817, 909, 1000, $1035,1057,1105,1130,1154,1201,1253,1284,1305,1327$, $1373,1393,1424,1472,1551,1614,1686,2884,3088 \mathrm{~cm}^{-1} \cdot{ }^{1} \mathrm{H}$ NMR $\left(\mathrm{CDCl}_{3}\right) \delta 1.95-2.06\left(\mathrm{~m}, 2 \mathrm{H}, \mathrm{CH}_{2} \mathrm{CH}_{2}-\mathrm{C}=\mathrm{O}\right), 2.33-2.46(\mathrm{~m}$, $\left.2 \mathrm{H}, \mathrm{CH}_{2}-\mathrm{C}=\mathrm{O}\right), 3.69(\mathrm{~s}, 3 \mathrm{H}, \mathrm{Me}), 3.80(\mathrm{~d}, 1 \mathrm{H}, \mathrm{J}=16.3 \mathrm{~Hz}, \mathrm{CH}-$ indolyl), 3.83-3.87 (m, 2H, CH $-\mathrm{N}), 3.91(\mathrm{~d}, 1 \mathrm{H}, J=16.3 \mathrm{~Hz}$ $\mathrm{CH} H$-indolyl), $4.05(\mathrm{t}, 1 \mathrm{H}, J=2.2 \mathrm{~Hz}, \mathrm{H} 4), 4.07(\mathrm{~s}, 1 \mathrm{H}, \mathrm{H} 3), 4.22$ (s, 5H, Cp), $4.49(\mathrm{~s}, 1 \mathrm{H}, \mathrm{H} 5), 6.69(\mathrm{~s}, 1 \mathrm{H}, \mathrm{H} 2$ '), $7.12(\mathrm{t}, 1 \mathrm{H}, \mathrm{J}=$ $\left.7.4 \mathrm{~Hz}, \mathrm{H} 5^{\prime}\right), 7.22\left(\mathrm{t}, 1 \mathrm{H}, J=7.2 \mathrm{~Hz}, \mathrm{H} 6^{\prime}\right), 7.27(\mathrm{~d}, 1 \mathrm{H}, J=8.2 \mathrm{~Hz}$, $\left.\mathrm{H} 7^{\prime}\right), 7.60\left(\mathrm{~d}, 1 \mathrm{H}, \mathrm{J}=8.0 \mathrm{~Hz}, \mathrm{H} 4{ }^{\prime}\right) ;{ }^{13} \mathrm{C} \mathrm{NMR}\left(\mathrm{CDCl}_{3}\right) \delta 19.0\left(\mathrm{CH}_{2}\right.$ $\left.\mathrm{CH}_{2} \mathrm{CH}_{2}-\mathrm{C}=\mathrm{O}\right), 24.2\left(\mathrm{CH}_{2}\right.$-indolyl), $32.1\left(\mathrm{CH}_{2}, \mathrm{CH}_{2}-\mathrm{C}=\mathrm{O}\right), 32.7$ $\left(\mathrm{CH}_{3}, \mathrm{Me}\right), 52.4\left(\mathrm{CH}_{2}, \mathrm{CH}_{2}-\mathrm{N}\right), 64.2(\mathrm{CH}, \mathrm{C} 4), 65.4(\mathrm{CH}, \mathrm{C} 5)$, 67.6 (CH, C3), $69.6(5 \mathrm{CH}, \mathrm{Cp}), 81.8$ (C, C2, $\mathrm{C}_{-} \mathrm{CH}_{2}$-indolyl), 94.1 (C, C1, C-N), 109.2 (CH, C7', C7-indolyl), 114.0 (C, C3', C3indolyl), $118.8(\mathrm{CH}, \mathrm{C5}$ ', C5-indolyl), 118.9 (CH, C4', C4-indolyl), 121.5 ( $\mathrm{CH}, \mathrm{C6}$ ', C6-indolyl), 127.1 ( $\mathrm{CH}, \mathrm{C2}$ ', C2-indolyl), 127.7 (C, Cb-indolyl), 137.0 (C, Ca-indolyl), 175.2 (C, Me-C=O).

General procedure 2. The iodoferrocene $(1.0 \mathrm{mmol})$, Cul $(0.19$ $\mathrm{g}, 1.0 \mathrm{mmol})$, tBuOK $(0.11 \mathrm{~g}, 2.0 \mathrm{mmol})$ and acetamide $(65 \mathrm{mg}$ $1.1 \mathrm{mmol}$ ) were introduced in a degassed Schlenk tube and dissolved in DMSO $(2 \mathrm{~mL})$. The mixture was stirred under argon and heated at $90{ }^{\circ} \mathrm{C}$ overnight. It was then allowed to cool to room temperature before addition of water $(10 \mathrm{~mL})$. After extraction with AcOEt $(3 \times 20 \mathrm{~mL})$ and drying over $\mathrm{MgSO}_{4}$, the coupling product was purified by chromatography over silica gel (the eluent is given in the product description)

$\mathrm{N}$-(2-(Methoxymethyl)ferrocenyl)acetamide $\quad(\mathbf{2 d}, \quad$ racemic mixture). The general procedure 2 from 1-iodo-2 (methoxymethyl)ferrocene (1d; $0.36 \mathrm{~g}$ ) gave 2d (eluent: hexaneAcOEt $60: 40)$ in $19 \%$ yield $(56 \mathrm{mg})$ as an orange solid. The analyses are as reported before in the present paper.

$\mathrm{N}$-(2-(Methoxycarbonyl)ferrocenyl)acetamide (2i, racemic mixture). The general procedure 2 from methyl 2iodoferrocenecarboxylate (1i; $0.37 \mathrm{~g})$ gave $\mathbf{2 i}$ (eluent: hexaneAcOEt $60: 40)$ in $4.5 \%$ yield $(13 \mathrm{mg})$ as an orange solid. The analyses are as reported before in the present paper.

\section{$\mathrm{N}$-(2-(Diisopropylaminocarbonyl)ferrocenyl)acetamide} racemic mixture). The general procedure 2 from $\mathrm{N}, \mathrm{N}$-diisopropyl2-iodoferrocenecarboxamide $(\mathbf{1 j} ; 0.44 \mathrm{~g})$ gave $\mathbf{2 j}$ (eluent: hexane-AcOEt $60: 40)$ in $6.5 \%$ yield $(23 \mathrm{mg}$ ) as an orange solid. The analyses are as reported before in the present paper.

Computational Details. All electronic structure calculations were conducted using Gaussian 09 suite. ${ }^{[50]}$ Full geometry optimizations of the considered species were performed using the B3LYP hybrid functional. ${ }^{[51]}$ Before optimizing the geometry, a conformational search has been done for structurally flexible species. Vibrational frequencies were calculated to prove the nature of the stationary points and to derive thermochemical corrections for enthalpies and free energies. The LANL2DZ basis set ${ }^{[52]}$ with the effective core potential was used to describe $\mathrm{Fe}, \mathrm{Cu}$, and I, while the $6-31 \mathrm{G}(\mathrm{d})$ basis set ${ }^{[53]}$ was used to treat the rest of the atoms. The free energy of activation was calculated as the difference between the free energy of the transition-state structure and the sum of the free energies of the initial [(dmeda)Cu(pyrr)] complex and iodobenzene or iodoferrocene. We used LANL2TZ(f) basis set ${ }^{[54]}$ for Fe and $\mathrm{Cu}$ atoms and LANL2DZ(d,p) basis set ${ }^{[55]}$ for I atom for the free energy calculation. Mulliken, APT and NBO atomic charges were obtained at the same level using different population analysis schemes in Gaussian 09. For generation of Hirshfeld atomic charges and various conceptual DFT (CDFT) reactivity indices Multiwfn program ${ }^{[56]}$ was used.

The polarizable continuum model (IEF-PCM) ${ }^{[57]}$ was used to account for solvation effects with a default parameters of 1,4 dioxane to emulate the reaction conditions. 
CDFT is aiming for unraveling of reactivity of chemical systems. ${ }^{[58]}$ Its descriptors can be used to predict favorable reactive sites and compare reactivity of different species. In the present work the following properties were calculated: global - frontier orbital energies ( $\left.E_{\text {HомO }}, E_{\text {LUMO }}\right)$, Mulliken electronegativity $(\chi)$, hardness $(\eta)$, electrophilicity index $(\omega)$, nucleophilicity index $(\mathrm{Nu})$;

local - condensed Fukui function for nucleophilic $\left(f_{+}\right)$, electrophilic $(f-)$ and radical attack (fo); condensed local softness for nucleophilic $(s+)$, electrophilic $\left(s^{-}\right)$and radical attack $(s 0)$; relative electrophilicity index (sr), condensed local electrophilicity index $\left(\omega^{\mathrm{loc}}\right)$, condensed local nucleophilicity index $\left(\mathrm{Nu}{ }^{\mathrm{loc}}\right)$.

Their thorough definition and explanation could be found elsewhere. ${ }^{[58-59]}$

\section{Acknowledgements}

This work was supported by the Université de Rennes 1 and CNRS. The authors would like to thank Rennes Métropole for a doctoral mobility fellowship (L. K.) and Région Bretagne for a postdoctoral fellowship grant (L. K.). We gratefully acknowledge the Fonds Européen de Développement Régional (FEDER; D8 Venture Bruker AXS diffractometer) and Thermofisher (generous gift of 2,2,6,6-tetramethylpiperidine). This research has been performed as part of the Indo-French 'Joint Laboratory for Natural Products and Synthesis towards Affordable Health'.

\section{References}

[1] I. Goldberg, Ber. Dtsch. chem. Ges. 1906, 39, 1691-1692.

[2] a) I. P. Beletskaya, A. V. Cheprakov, Coord. Chem. Rev. 2004, 248, 2337-2364; b) G. Evano, N. Blanchard, M. Toumi, Chem. Rev. 2008, 108, 3054-3131; c) F. Monnier, M. Taillefer, Angew. Chem. 2009, 121, 7088-7105; Angew. Chem. Int. Ed. 2009, 48, 6954-6971; d) I. P. Beletskaya, A. V. Cheprakov, Organometallics 2012, 31, 7753-7808; e) J. Bariwal, E. Van der Eycken, Chem. Soc. Rev. 2013, 42, 9283-9303; f) F. Monnier, M. Taillefer, Top. Organomet. Chem. 2013, 46, 173204; g) C. Sambiagio, S. P. Marsden, A. J. Blacker, P. C. McGowan, Chem. Soc. Rev. 2014, 43, 3525-3550; h) A. M. Thomas, A. Sujatha, G. Anilkumar, Mini-Rev. Org. Chem. 2015, 12, 3-23.

[3] G. X. Yang, L. L. Chang, Q. Truong, G. A. Doherty, P. A. Magriotis, S. E. de Laszlo, B. Li, M. MacCoss, U. Kidambi, L. A. Egger, E. McCauley, G. Van Riper, R. A. Mumford, J. A. Schmidt, W. K. Hagmann, Bioorg. Med. Chem. Lett. 2002, 12, 1497-1500.

[4] T. Beghyn, C. Hounsou, B. P. Deprez, Bioorg. Med. Chem. Lett. 2007, 17, 789-792.

[5] T. B. Beghyn, J. Charton, F. Leroux, G. Laconde, A. Bourin, P. Cos, L. Maes, B. Deprez, J. Med. Chem. 2011, 54, 3222-3240.

[6] H. Bregman, N. Chakka, A. Guzman-Perez, H. Gunaydin, Y. Gu, X. Huang, V. Berry, J. Liu, Y. Teffera, L. Huang, B. Egge, E. L. Mullady, S. Schneider, P. S. Andrews, A. Mishra, J. Newcomb, R. Serafino, C. A. Strathdee, S. M. Turci, C. Wilson, E. F. DiMauro, J. Med. Chem. 2013, 56, 4320-4342.

[7] M. J. Orwat, J. X. Qiao, K. He, A. R. Rendina, J. M. Luettgen, K. A. Rossi, B. Xin, R. M. Knabb, R. R. Wexler, P. Y. S. Lam, D. J. P. Pinto, Bioorg. Med. Chem. Lett. 2014, 24, 3341-3345.

[8] J. L. Woodring, K. A. Bachovchin, K. G. Brady, M. F. Gallerstein, J. Erath, S. Tanghe, S. E. Leed, A. Rodriguez, K. Mensa-Wilmot, R. J. Sciotti, M. P. Pollastri, Eur. J. Med. Chem. 2017, 141, 446-459.
[9] B.-R. Kang, A.-L. Shan, Y.-P. Li, J. Xu, S.-M. Lu, S.-Q. Zhang, Bioorg. Med. Chem. 2013, 21, 6956-6964.

[10] a) A. Klapars, J. C. Antilla, X. Huang, S. L. Buchwald, J. Am. Chem. Soc. 2001, 123, 7727-7729; b) A. Klapars, X. Huang, S. L. Buchwald, J. Am. Chem. Soc. 2002, 124, 7421-7428.

[11] a) E. R. Strieter, D. G. Blackmond, S. L. Buchwald, J. Am. Chem. Soc. 2005, 127, 4120-4121; b) E. R. Strieter, B. Bhayana, S. L. Buchwald, J. Am. Chem. Soc. 2009, 131, 7888; c) J. W. Tye, Z. Weng, A. M. Johns, C. D. Incarvito, J. F. Hartwig, J. Am. Chem. Soc. 2008, 130, 9971-9983.

[12] a) S.-L. Zhang, L. Liu, Y. Fu, Q.-X. Guo, Organometallics 2007, 26, 4546-4554; b) A. Casitas, X. Ribas, Chem. Sci. 2013, 4, 2301-2318; c) I. Güell, X. Ribas, Eur. J. Org. Chem. 2014, 2014, 3188-3195; d) X. Ribas, I. Güell, Pure Appl. Chem. 2014, 86, 345-360; e) K. K. Gurjar, R. K. Sharma, ChemCatChem 2017, 9, 862-869; f) M. Rovira, L. Jašiková, E. Andris, F. Acuña-Parés, M. Soler, I. Güell, M.-Z. Wang, L. Gómez, J. M. Luis, J. Roithová, X. Ribas, Chem. Commun. 2017, 53, 87868789.

[13] M.-G. Wang, H. Yu, J. Wu, Z.-C. Shang, Synthesis 2013, 45, 1955-1964

[14] D. Astruc, Eur. J. Inorg. Chem. 2017, 2017, 6-29.

[15] F. A. Larik, A. Saeed, T. A. Fattah, U. Muqadar, P. A. Channar, Appl. Organomet. Chem. 2017, 31, e3664.

[16] a) M. Herberhold, M. Ellinger, W. Kremnitz, J. Organomet. Chem. 1983, 241, 227-240; b) B. Bildstein, M. Malaun, H. Kopacka, K.-H. Ongania, K. Wurst, J. Organomet. Chem. 1999, 572, 177-187; c) S. Özçubukçu, E. Schmitt, A. Leifert, C. Bolm, Synthesis 2007, 389-392 (conditions: Cul (1 equiv), tBuOK (2 equiv) in DMSO at $90^{\circ} \mathrm{C}$ for $14 \mathrm{~h}$ ).

[17] P. Srinivas, S. Prabhakar, F. Chevallier, E. Nassar, W. Erb, V. Dorcet, V. Jouikov, P. Radha Krishna, F. Mongin, New J. Chem. 2016, 40, 9441-9447.

[18] L. Kadari, W. Erb, T. Roisnel, P. R. Krishna, F. Mongin, New J. Chem. 2020, DOI: 10.1039/D0NJ03470C.

[19] a) M. Tazi, W. Erb, Y. S. Halauko, O. A. Ivashkevich, V. E. Matulis, T. Roisnel, V. Dorcet, F. Mongin, Organometallics 2017, 36, 4770-4778; b) W. Erb, G. Levanen, T. Roisnel, V. Dorcet, New J. Chem. 2018, 42, 3808-3818; c) M. Tazi, M. Hedidi, W. Erb, Y. S. Halauko, O. A. Ivashkevich, V. E. Matulis, T. Roisnel, V. Dorcet, G. Bentabed-Ababsa, F. Mongin, Organometallics 2018, 37, 2207-2211; d) W. Erb, J.-P. Hurvois, T. Roisnel, V. Dorcet, Organometallics 2018, 37, 3780-3790; e) W. Erb, T. Roisnel, Chem. Commun. 2019, 55, 9132-9135; f) M. Hedidi, G. Dayaker, Y. Kitazawa, T. Yoshii, M. Kimura, W. Erb, G. Bentabed-Ababsa, F. Chevallier, M. Uchiyama, P. C. Gros, F. Mongin, New J. Chem. 2019, 43, 14898-14907; g) M. Tazi, W. Erb, T. Roisnel, V. Dorcet, F. Mongin, P. J. Low, Org Biomol. Chem. 2019, 17, 9352-9359; h) W. Erb, T. Roisnel, V. Dorcet, Synthesis 2019, 51, 3205-3213; i) W. Erb, L. Kadari, K. Al-Mekhlafi, T. Roisnel, V. Dorcet, P. Radha Krishna, F. Mongin, Adv. Synth. Catal. 2020, 362, 832-850; j) L. Kadari, T. Roisnel, W. Erb, P. R. Krishna, F. Mongin, Synthesis 2020, 52, 10.1055/s-0040-1707175.

[20] a) M. Rovira, M. Soler, I. Güell, M.-Z. Wang, L. Gómez, X. Ribas, J. Org. Chem. 2016, 81, 7315-7325; b) A. Casitas, M. Canta, M. Solà, M. Costas, X. Ribas, J. Am. Chem. Soc. 2011, 133, 19386-19392.

[21] a) C. Y. Legault, Y. Garcia, C. A. Merlic, K. N. Houk, J. Am. Chem. Soc. 2007, 129, 12664-12665; b) Y. Garcia, F. Schoenebeck, C. Y. Legault, C. A. Merlic, K. N. Houk, J. Am. Chem. Soc. 2009, 131, 6632-6639. 
[22] a) R. Rossi, F. Bellina, M. Lessi, Adv. Synth. Catal. 2012, 354, 1181-1255; b) J. Almond-Thynne, D. C. Blakemore, D. C. Pryde, A. C. Spivey, Chem. Sci. 2017, 8, 40-62.

[23] S. T. Handy, Y. Zhang, Chem. Commun. 2006, 42, 299-301.

[24] I. J. S. Fairlamb, C. T. O'Brien, Z. Lin, K. C. Lam, Org. Biomol. Chem. 2006, 4, 1213-1216.

[25] G. Dayaker, A. Sreeshailam, F. Chevallier, T. Roisnel, P. Radha Krishna, F. Mongin, Chem. Commun. 2010, 46, 28622864.

[26] C. Metallinos, J. Zaifman, L. Dodge, Org. Lett. 2008, 10, 35273530.

[27] B. Speetzen, S. R. Kass, J. Phys. Chem. A 2019, 123, 60166021.

[28] W. F. Bailey, E. A. Cioffi, K. B. Wiberg, J. Org. Chem. 1981, 46, 4219-4225.

[29] C. Amatore, B. Godin, A. Jutand, B. Ferber, S. Top, G. Jaouen, Organometallics 2007, 26, 3887-3890.

[30] S. Zhang, Y. Ding, Organometallics 2011, 30, 633-641.

[31] M. S. Inkpen, S. Du, M. Hildebrand, A. J. P. White, N. M. Harrison, T. Albrecht, N. J. Long, Organometallics 2015, 34, 5461-5469.

[32] a) M. W. Hooper, M. Utsunomiya, J. F. Hartwig, J. Org. Chem. 2003, 68, 2861-2873; b) M. W. Hooper, J. F. Hartwig, Organometallics 2003, 22, 3394-3403.

[33] a) I. Bennacef, C. A. Salinas, T. A. Bonasera, R. N. Gunn, H. Audrain, S. Jakobsen, N. Nabulsi, D. Weinzimmer, R. E. Carson, Y. Huang, I. Holmes, F. Micheli, C. Heidbreder, G. Gentile, T. Rossi, M. Laruelle, Bioorg. Med. Chem. Lett. 2009, 19, 5056-5059; b) S. Terentjeva, D. Muceniece, V. Lūsis, J. Chem. Res. 2015, 39, 701-705.

[34] F. Yamada, M. Tamura, M. Somei, Heterocycles 1998, 49, 451-457.

[35] T. Cohen, I. Cristea, J. Org. Chem. 1975, 40, 3649-3651.

[36] S. R. Flanagan, D. C. Harrowven, M. Bradley, Tetrahedron Lett. 2003, 44, 1795-1798.

[37] H. E. Gottlieb, V. Kotlyar, A. Nudelman, J. Org. Chem. 1997, 62, 7512-7515.

[38] M. S. Inkpen, S. Du, M. Driver, T. Albrecht, N. J. Long, Dalton Trans. 2013, 42, 2813-2816.

[39] G. M. Sheldrick, Acta Crystallogr., Sect. A 2015, 71, 3-8.

[40] G. M. Sheldrick, Acta Crystallogr., Sect. C 2015, 71, 3-8.

[41] L. J. Farrugia, J. Appl. Crystallogr. 1997, 30, 565.

[42] M. Tsukazaki, M. Tinkl, A. Roglans, B. J. Chapell, N. J. Taylor, V. Snieckus, J. Am. Chem. Soc. 1996, 118, 685-686.

[43] A. Zirakzadeh, R. Schuecker, W. Weissensteiner, Tetrahedron: Asymmetry 2010, 21, 1494-1502.

[44] T. Pickett, E., F. Roca, X., C. Richards, J., J. Org. Chem. 2003, 68, 2592-2599.

[45] a) A. Patti, D. Lambusta, M. Piattelli, G. Nicolosi, Tetrahedron: Asymmetry 1998, 9, 3073-3080; b) G. Dayaker, A. Sreeshailam, D. V. Ramana, F. Chevallier, T. Roisnel, S.
Komagawa, R. Takita, M. Uchiyama, P. R. Krishna, F. Mongin, Tetrahedron 2014, 70, 2102-2117.

[46] S. Pedotti, A. Patti, Tetrahedron 2012, 68, 3300-3305.

[47] H. Lehner, K. Schlögl, Monatsh. Chem. 1970, 101, 895-911.

[48] a) O. Riant, O. Samuel, T. Flessner, S. Taudien, H. B. Kagan, J. Org. Chem. 1997, 62, 6733-6745; b) G. Forcher, A. Silvanus, P. de Fremont, B. Jacques, M. S. M. Pearson-Long, F. Boeda, P. Bertus, J. Organomet. Chem. 2015, 797, 1-7.

[49] G. Pavlović, L. Barisic, V. Rapic, I. Leban, Acta Crystallographica, Section E: Structure Reports Online 2002, 58, m13-m15.

[50] M. J. Frisch, G. W. Trucks, H. B. Schlegel, G. E. Scuseria, M. A. Robb, J. R. Cheeseman, G. Scalmani, V. Barone, B. Mennucci, G. A. Petersson, H. Nakatsuji, M. Caricato, X. Li, H. P. Hratchian, A. F. Izmaylov, J. Bloino, G. Zheng, J. L. Sonnenberg, M. Hada, M. Ehara, K. Toyota, R. Fukuda, J. Hasegawa, M. Ishida, T. Nakajima, Y. Honda, O. Kitao, H. Nakai, T. Vreven, J. Montgomery, J. A., J. E. Peralta, F. Ogliaro, M. Bearpark, J. J. Heyd, E. Brothers, K. N. Kudin, V. N. Staroverov, R. Kobayashi, J. Normand, K. Raghavachari, A. Rendell, J. C. Burant, S. S. lyengar, J. Tomasi, M. Cossi, N. Rega, J. M. Millam, M. Klene, J. E. Knox, J. B. Cross, V. Bakken, C. Adamo, J. Jaramillo, R. Gomperts, R. E. Stratmann, O. Yazyev, A. J. Austin, R. Cammi, C. Pomelli, J. W. Ochterski, R. L. Martin, K. Morokuma, V. G. Zakrzewski, G. A. Voth, P. Salvador, J. J. Dannenberg, S. Dapprich, A. D. Daniels, Ö. Farkas, J. B. Foresman, J. V. Ortiz, J. Cioslowski, D. J. Fox, Gaussian 09, Revision A.02, Gaussian Inc., Wallingford, CT, 2009.

[51] a) A. D. Becke, J. Chem. Phys. 1993, 98, 5648-5652; b) C. Lee, W. Yang, R. G. Parr, Phys. Rev. B 1988, 37, 785-789.

[52] P. J. Hay, W. R. Wadt, J. Chem. Phys. 1985, 82, 299-310.

[53] P. C. Hariharan, J. A. Pople, Theor. Chim. Acta 1973, 28, 213222.

[54] a) L. E. Roy, P. J. Hay, R. L. Martin, J. Chem. Theory Comput. 2008, 4, 1029-1031; b) A. W. Ehlers, M. Böhme, S. Dapprich, A. Gobbi, A. Höllwarth, V. Jonas, K. F. Köhler, R. Stegmann, A. Veldkamp, G. Frenking, Chem. Phys. Lett. 1993, 208, 111 114.

[55] a) W. R. Wadt, P. J. Hay, J. Chem. Phys. 1985, 82, 284-298; b) C. E. Check, T. O. Faust, J. M. Bailey, B. J. Wright, T. M. Gilbert, L. S. Sunderlin, J. Phys. Chem. A 2001, 105, 8111 8116.

[56] T. Lu, F. Chen, J. Comput. Chem. 2012, 33, 580-592.

[57] E. Cances, B. Mennucci, J. Tomasi, J. Chem. Phys. 1997, 107, 3032-3041.

[58] R. Parr, W. Yang in Density Functional Theory of Atoms and Molecules; Oxford University Press: New York, 1989.

[59] a) R. K. Roy, S. Krishnamurti, P. Geerlings, S. Pal, J. Phys. Chem. A 1998, 102, 3746-3755; b) W. Yang, R. G. Parr, Proc Natl. Acad. Sci. U. S. A. 1985, 82, 6723-6726; c) P. Geerlings, F. De Proft, Phys. Chem. Chem. Phys. 2008, 10, 3028-304. 